\title{
Auswirkungen von \\ Habitatfragmentierung und Landschaftsstruktur auf Tagfalter und Blütenpflanzen
}

\author{
Dissertation \\ zur Erlangung des Doktorgrades \\ der Fakultät für Agrarwissenschaften \\ der Georg-August-Universität Göttingen
}

\author{
vorgelegt von \\ Jochen Krauß \\ geboren in Stuttgart
}

Göttingen, Mai 2003 
1. Referent: Prof. Dr. Teja Tscharntke

2. Korreferent: Prof. Dr. Stefan Vidal

Tag der mündlichen Prüfung: 22.05.2003 


\section{Inhaltsverzeichnis}

1 Auswirkungen von Habitatfragmentierung und Landschaftsstruktur auf

Tagfalter und Blütenpflanzen. Ein Überblick...................................................... 6

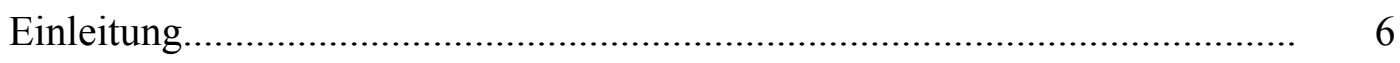

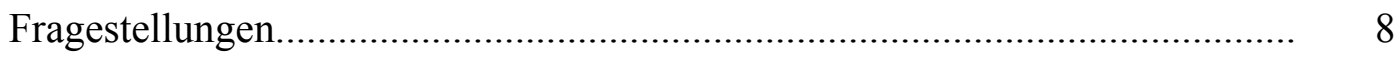

Organismen und Habitat.............................................................................. 10

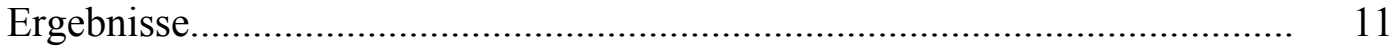

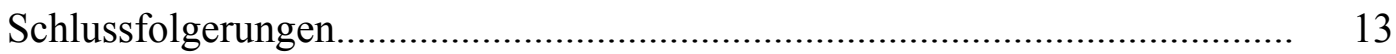

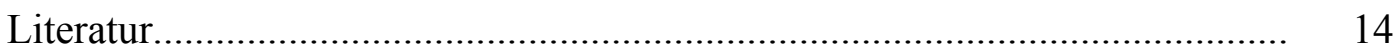

2 Local species immigration, extinction, and turnover of butterflies in relation to habitat area and habitat isolation....................................................................... $\quad 18$

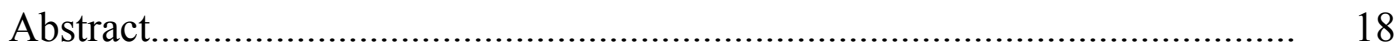

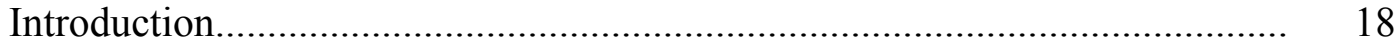

Material and Methods.................................................................................... 21

Study region and study sites $\cdot$ Butterflies $\cdot$ Local species immigration,

extinction, and turnover $\cdot$ Statistical analyses

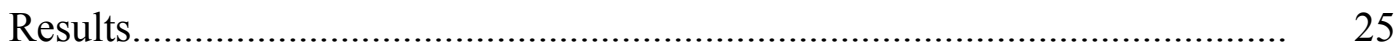

Species-area and species isolation relationships $\cdot$ Immigration, extinction, and

turnover events $\cdot$ Immigration, extinction, and turnover rates

Discussion

Biogeography and theory $\cdot$ Conclusions for conservation

Acknowledgements............................................................................ 34

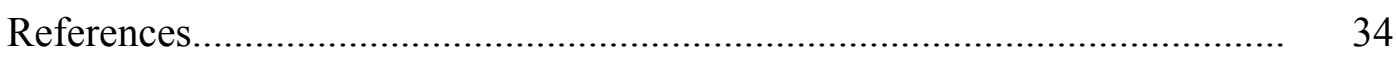

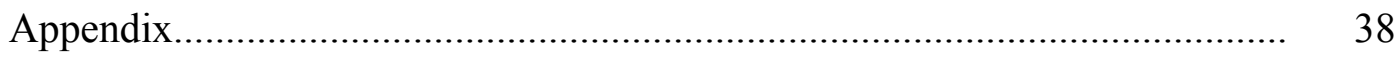

3 How does landscape context contribute to effects of habitat fragmentation on diversity and population density of butterflies?.................................................... $\quad 40$

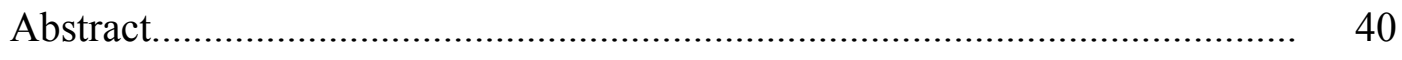

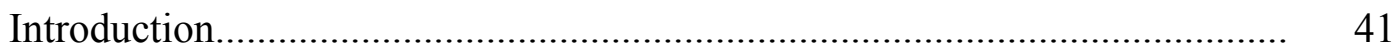


Material and Methods

Study region and study sites $\cdot$ Butterflies $\cdot$ Habitat area, isolation, quality, and

the landscape context $\cdot$ Statistical analyses

Results.

Species richness of butterflies $\cdot$ Density of butterflies

Discussion.

Species richness of butterflies $\cdot$ Density of butterflies

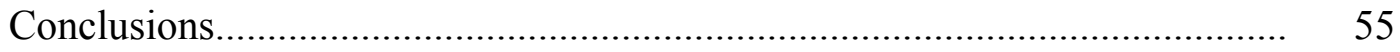

Acknowledgements............................................................................... 56

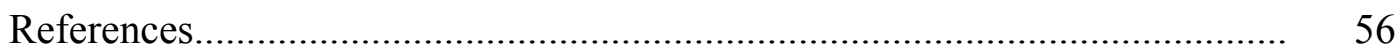

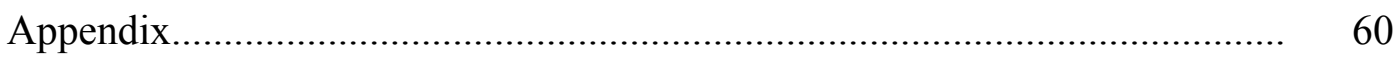

\section{Effects of habitat area, isolation, and landscape diversity on plant species} richness of calcareous grasslands............................................................................ 61

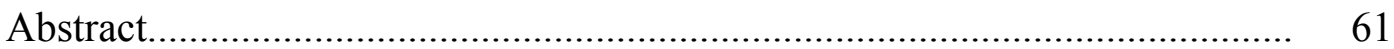

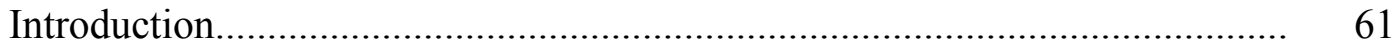

Material and Methods.......................................................................... 63

Study region and study sites $\cdot$ Habitat area, isolation, landscape diversity $•$

Plants $\cdot$ Statistical analyses

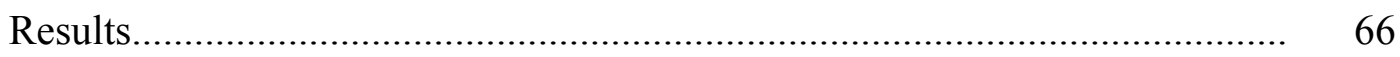

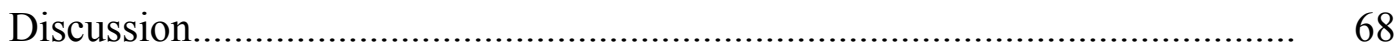

Acknowledgements................................................................................. 71

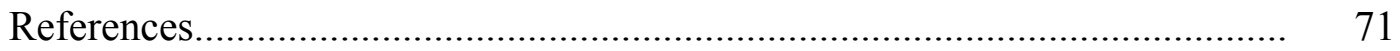

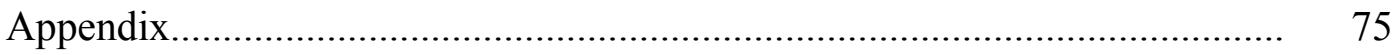

5 Effects of habitat fragmentation on the genetic structure of the monophagous butterfly Polyommatus coridon along its northern range margin........................... $\quad 76$

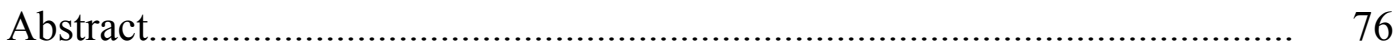

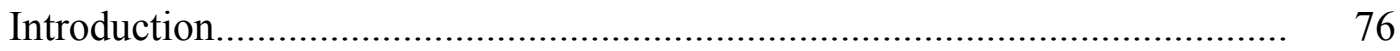

Material and Methods................................................................................... $\quad 78$

Study region and study sites $\bullet$ Study species $\bullet$ Population size, habitat isolation and food plant availability $\cdot$ Sampling, genetic and statistical analyses

Results. 
Discussion

Regional differences of the genetic structure $\cdot$ Genetic differentiation between populations $\cdot$ Isolation by distance $\cdot$ Differences between sub-regions $\cdot$ Effects of habitat fragmentation on genetic diversity $\cdot$ Conclusions

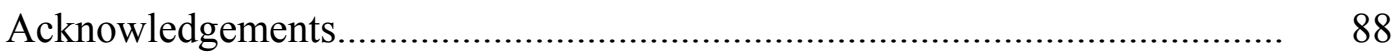

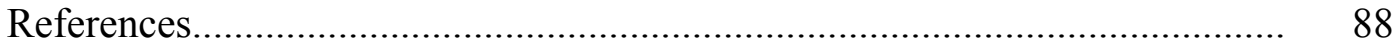

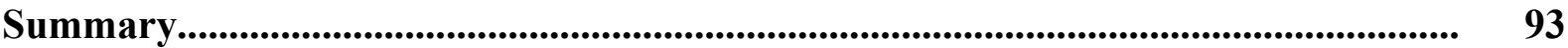

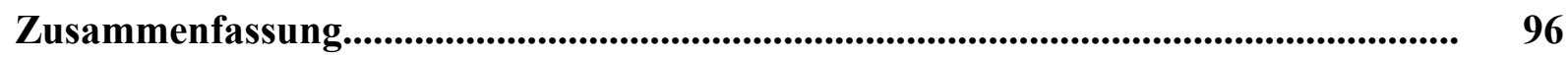

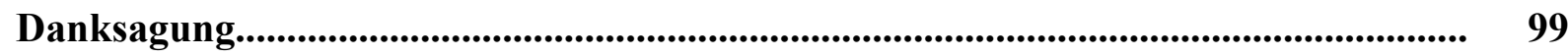

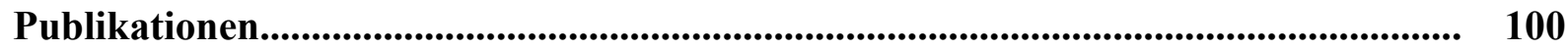

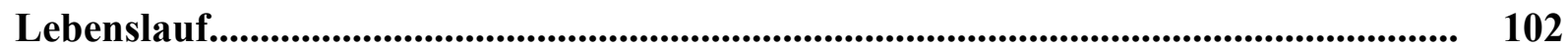




\section{Auswirkungen von Habitatfragmentierung und \\ Landschaftsstruktur auf Tagfalter und Blütenpflanzen. Ein \\ Überblick.}

\section{EINLEITUNG}

In den letzten Jahrzehnten hat sich das Bild unserer Kulturlandschaft drastisch verändert. Die flächendeckende Erschließung der Landschaft und gleichzeitige Intensivierung der Landnutzung führte zu einer deutlichen Flächenreduktion naturnaher und halbnatürlicher Ökosysteme und zur Fragmentierung der verbliebenen Habitate (Plachter 1991, Jedicke 1994). Besonders betroffen sind hiervon die halbnatürlichen Kalkmagerrasen, die in den letzten Jahrzehnten stark abgenommen haben (WallisDeVries et al. 2002). So wurde dokumentiert, dass z. B. im Regierungsbezirk Stuttgart (Baden-Württemberg) der Flächenverlust seit 1900 bei 61 \% liegt (Mattern et al. 1980, 1992, WallisDeVries et al. 2002). In der Untersuchungsregion in Süd-Niedersachsen war der Flächenverlust in den letzten Jahrzehnten vermutlich ebenfalls hoch. Zudem führt der geringe Anteil an Kalkuntergrund bereits auf natürliche Weise zur Fragmentierung der Flächen. Trotzdem zählen Kalkmagerrasen für Insekten und Pflanzen auch heute noch zu den artenreichsten Habitaten Mitteleuropas (VanSwaay 2002, WallisDeVries et al. 2002). Parallel zu dem Rückgang von naturnahen und halbnatürlichen Habitaten in Mittel- und Nordeuropa nahm auch die Diversität der Tagfalter in vielen Regionen extrem ab. So gingen in Suffolk, UK in den letzten 150 Jahren 42 \% (Bourn \& Thomas 2002) und in Flandern, Belgien in den letzten 100 Jahren 30 \% (Maes \& Van Dyck 2001) der Arten verloren. Auch Pflanzenarten sind von der Abnahme naturnaher und halbnatürlicher Habitate betroffen, wenn auch in geringerem Ausmaß als Tagfalter. So gelten $5 \%$ der Blütenpflanzen in Suffolk, UK seit den letzten 150 Jahren als ausgestorben (Bourn \& Thomas 2002). Spezialisierte Pflanzenarten der Kalkmagerrasen sind in Deutschland zu $1 \%$ ausgestorben und zu $42 \%$ gefährdet (WallisDeVries et al. 2002).

Unter Habitatfragmentierung versteht man die Verinselung von Festlandhabitaten, die mit abnehmender Habitatgröße und zunehmender Isolation einhergehen. Habitatfragmentierung und Habitatverlust steigern Extinktionsraten und gehören mit zu den 
Hauptgründen für den lokalen, regionalen und globalen Diversitätsverlust (Begon et al. 1996, Whittaker1998).

Habitatverlust und Habitatfragmentierung trifft aber auch innerhalb einer Artengruppe nicht alle Arten gleichermaßen (Pimm 1991, Lawton 1995, Tscharntke et al. 2002a). Insbesondere seltene Arten (Pimm 1991, Gaston 1994, Lawton 1995), Arten mit hoher Populations-Variabilität oder niedrigen Populationsdichten (Pimm 1991, Kruess \& Tscharntke 1994, Lawton 1995, Zabel \& Tscharntke 1998), Nahrungsspezialisten (Zabel \& Tscharntke 1998, Steffan-Dewenter \& Tscharntke 2000), Arten mit geringer Ausbreitungsfähigkeit (Bunce \& Howard 1990, Lawton 1995, De Vries et al. 1996, Bender et al. 1998) und Arten in höherer trophischer Position (Pimm 1991, Lawton 1995, Holt et al. 1999, Tscharntke \& Kruess 1999, Davies et al. 2000) gelten als besonders sensibel gegenüber Fragmentierung. Habitatspezialisten sind häufig durch eine Kombination mehrerer der eben aufgezählten Eigenschaften charakterisiert (Lawton 1995, Fischer \& Stöcklin 1997, Warren et al. 2001, Brändle et al. 2002). Habitatspezialisten gelten daher als besonders anfällig gegen Habitatfragmentierung, wie Studien zu Blütenpflanzen (Fischer \& Stöcklin 1997) und zu Tagfaltern belegen (Thomas et al. 1992, Warren et al. 2001). Habitatgeneralisten sollten dagegen durch die umgebende Landschaftsstruktur stärker beeinflusst sein (Jonson \& Fahrig 1997). Die Einteilung in Habitatspezialisten und Habitatgeneralisten ist somit eine wichtige Grundvoraussetzung um Auswirkungen von Habitatfragmentierung und Landschaftsstruktur zu verstehen. Trotzdem werden Arten nur selten in solche ökologischen Gruppen eingeteilt (siehe aber z. B. Warren et al. 2001). Selbst bei den sonst gut erforschten Arten-ArealBeziehungen fehlen diese Einteilungen weitestgehend (Harrison \& Bruna 1999). Die Einteilung der Artengemeinschaft von Tagfaltern und Blütenpflanzen in Habitatspezialisten und Generalisten wurde in dieser Arbeit in den Kapiteln 2 - 4 berücksichtigt.

Die Inselbiogeographie wurde von MacArthur und Wilson entwickelt und basiert auf einem angenommenen Gleichgewichtszustand zwischen Immigrations- und Extinktionsraten auf Inseln. In einem zeitlichen Kontext sind auf kleinen isolierten Inseln die Extinktions- und Turnoverraten von Arten höher, Immigrationsraten dagegen niedriger, als auf großen weniger isolierten Inseln (MacArthur \& Wilson 1963, 1967, Rosenzweig 1995, Whittaker1998). Auch die Metapopulationstheorie, die im wesentlichen von Levins entwickelt wurde, basiert auf dem Konzept von Immigration und Extinktion. Allerdings geht es hierbei um lokale Populationen (Sub-Populationen), nicht um Artengemeinschaften, die durch einzelne dispergierende Individuen (Genfluss) miteinander verbunden sind (Levins 1969, Reich \& Grimm 1996, Hanski \& Gilpin 1997, Hanski \& Simberloff 1997, Settele 1998, Hanski 1999). 
Nur wenige Studien betrachten die zeitliche Dynamik von Artengemeinschaften und berechnen Immigrations-, Extinktions- und Turnoverraten (Manne et al. 1998), während für Einzelarten im Metapopulationskontext diese Berechnungen durchaus häufiger sind (z. B. Hanski \& Singer 2001). Die zeitliche Dynamik für Artengemeinschaften, der Inselbiogeographie folgend, wird in Kapitel 2 für Tagfalter näher untersucht.

Im Gegensatz zur Habitatgröße und der seltener untersuchten Habitatisolation (Rosenzweig 1995) werden die Auswirkungen der umgebenden Landschaftsstruktur auf Arten und Artengemeinschaften meist vernachlässigt (Wiens 1997, Hanski 1999, Vandermeer \& Carvajal 2001, Tscharntke et al. 2002b). In den Kapiteln 3 und 4 werden die Auswirkungen der Landschaftsstruktur mit einbezogen. Die Einflüsse all dieser Habitatfaktoren auf die Populationsdichten von Insekten sind weitestgehend unbekannt (Connor et al. 2000). In Kapitel 3 werden auch die Auswirkungen auf die Populationsdichten von Tagfaltern untersucht.

Arten-Areal-Beziehungen beschreiben die positive Beziehung zwischen Inselgröße (Habitatgröße) und Artenzahl. Zwei ökologische Hypothesen erklären Arten-ArealBeziehungen. Die Areal per se- oder Gleichgewichts-Hypothese geht von der Annahme aus, dass nur die Flächengröße, unabhängig von der Heterogenität der Flächen, die Zunahme der Artenzahl bestimmt und ein Gleichgewicht zwischen Immigration und Extinktion existiert. Die Habitatheterogenitäts-Hypothese dagegen erklärt die Artenzunahme durch zunehmende Flächenheterogenität größerer Flächen (Rosenzweig 1995, Holt et al. 1999). In Kapitel 4 wird für Blütenpflanzen auf Kalkmagerrasen untersucht, welche der beiden Hypothesen wahrscheinlicher ist.

Populationsgenetische Untersuchungen zur Auswirkung der Habitatfragmentierung auf Organismen beschränken sich meist auf die Effekte der Populationsgröße bzw. der Habitatgröße und vernachlässigen hierbei oft die Isolation von Habitaten (siehe Young et al. 1996, Amos \& Harwood 1998). In Kapitel 5 werden die Auswirkungen von Populationsgröße, Habitatgröße, Futterpflanzenvorkommen und Isolation auf die genetische Struktur und genetische Diversitität untersucht.

\section{FRAGESTELLUNGEN}

In der vorliegenden Arbeit sollen die Auswirkungen von Habitatfragmentierung und Landschaftsstruktur der Umgebung auf die Artenvielfalt und Abundanz von Tagfaltern und Pflanzen, sowie auf einen spezialisierten Tagfalter, Polyommatus coridon, (mit populationsgenetischen Methoden), untersucht werden. Hierbei sollen zunächst die 
Auswirkungen der Habitatfragmentierung auf Immigrations-, Extinktions- und Turnoverereignisse (zeitliche Dynamik) von Tagfalterarten analysiert werden (Kapitel 2). Daraufhin werden die zusätzlichen Einflüsse der Landschaftsstruktur auf Artenzahl und auf Populationsdichten von Tagfaltern untersucht (Kapitel 3). Die Folgen der Habitatfragmentierung und der Landschaftsstruktur werden auch für Blütenpflanzenarten und Blütenpflanzenartendichte untersucht (Kapitel 4). Schließlich werden die Auswirkungen der Fragmentierung auf die Populationsgenetik des Tagfalter Polyommatus coridon analysiert (Kapitel 5).

Im Einzelnen wurden folgende Fragestellungen bearbeitet:

\section{Zeitliche Dynamik (Kapitel 2)}

- Nehmen Immigrationsraten mit zunehmender Habitatgröße und abnehmender Isolation $\mathrm{zu}$ ?

- Nehmen Extinktions- und Turnoverraten mit zunehmender Habitatgröße und abnehmender Isolation ab?

- Haben Habitatspezialisten höhere Extinktions- und Turnoverraten als Generalisten und haben Generalisten höhere Immigrationsraten?

- Sterben Habitatspezialisten bei abnehmender Habitatgröße schneller aus als Generalisten?

\section{Habitatgröße, Isolation und Landschaftsstruktur (Kapitel 3 und 4)}

- Nimmt die Artenzahl mit zunehmender Habitatgröße, besserer Konnektivität und zunehmender Landschaftsdiversität der Umgebung zu?

- Reagieren Habitatspezialisten stärker auf Habitatgröße und Isolation, während Generalisten stärker auf Landschaftsstruktur reagieren?

- Wie reagieren die Populationsdichten von Tagfalter-Arten auf Habitatgröße, Isolation und Landschaftsstruktur?

- Ist die Pflanzenartendichte (= Artenzahl mit gleichem Probeaufwand auf allen Flächen) ebenfalls von Habitatgröße, Isolation und Landschaftsstruktur abhängig? 


\section{Populationsgenetik von Polyommatus coridon (Kapitel 5)}

- Zeigen Populationen von P. coridon am Nordrand der Verbreitung gegenüber der Kernregion eine reduzierte genetische Variabilität?

- Zeigen P. coridon Populationen eine signifikante genetische Strukturierung in der Untersuchungsregion?

- Lässt sich eine isolation by distance Struktur zwischen den Subpopulationen nachweisen?

- Unterscheiden sich P. coridon Populationen von zwei durch ein Flusstal getrennte Unterregionen genetisch?

- Beeinflussen die Populationsgröße, die Habitatgröße, die Distanz bis zur nächsten $P$. coridon Population und die Größe des Futterpflanzenvorkommens die genetische Diversität?

\section{ORGANISMEN UND HABITAT}

\section{Tagfalter und Blütenpflanzen}

In der vorliegenden Untersuchung wurden Tagfalter und Samenpflanzen (= Blütenpflanzen) auf Kalkmagerrasen erfasst. Zu den Tagfaltern (Lepidoptera: Hesperioidea und Papilionoidea) wurden auch die tagaktiven Widderchen (Lepidoptera: Zygaenidae) gezählt, zu den Samenpflanzen (Spermatophyta) zusätzlich die Art Equisetum arvense. Tagfalter und Blütenpflanzen gehören zu den am besten untersuchten Organismengruppen Europas und haben große Bedeutung für den Naturschutz (Beinlich \& Plachter 1995, Van Swaay 2002, WallisDeVries et al. 2002). Auf Grund der guten autökologischen Kenntnisse über die einzelnen Arten lassen sich beide Artengruppen in Habitatspezialisten für Kalkmagerrasen und Habitatgeneralisten einteilen (Kapitel 2 - 4).

Bei der Tagfalterart, Polyommatus coridon (Poda, 1761), wurden die Auswirkungen der Habitatfragmentierung auf die Populationsgenetik untersucht (Kapitel 5). P. coridon (Sillbergrüner Bläuling), gehört zu der Familie der Bläulinge (Lycaenidae) und ist ein univoltiner Tagfalter, der in der Untersuchungsregion in Südniedersachsen als Raupe monophag an Hippocrepis comosa L.

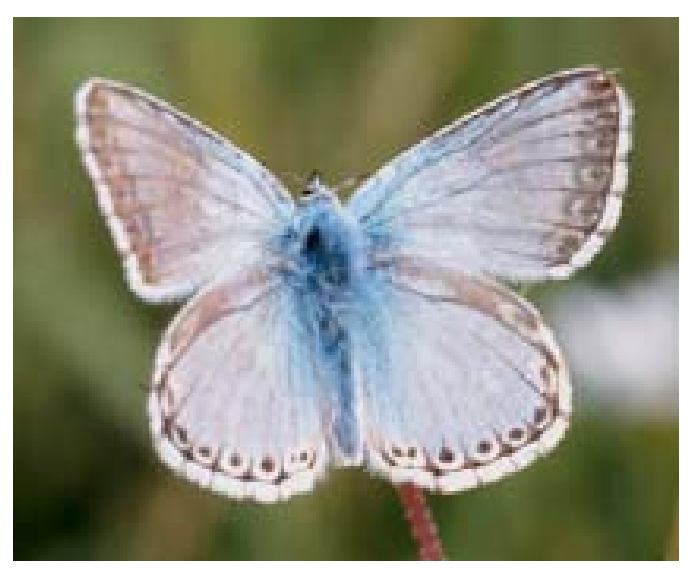

Fig. 1 Polyommatus coridon (Männchen) (Hufeisenklee) frisst (Ebert \& Rennwald 1991, Asher et al. 2001). Die Tagfalterart ist über 
weite Bereiche Mittel- und Südeuropas verbreitet (Kudrna 2002) und gilt als Kalkmagerrasenspezialist (Van Swaay 2002). In Südniedersachsen erreichen P. coridon und auch seine Larval-Futterpflanze H. comosa ihre nördliche Verbreitungsgrenze (Garve 1994, Kudrna 2002). Beide Arten gelten in Niedersachsen als gefährdet (Jedicke 1997). Die Populationsdichten von $P$. coridon sind im Vergleich zu anderen Tagfaltern sehr hoch (Ebert \& Rennwald 1991, Bink 1992, Weidemann 1995). Die Art wird zudem als standorttreu mit geringer Ausbreitungsfähigkeit eingestuft (Bink 1992, Weidemann 1995, Asher et al. 2001, Cowley et al. 2001).

\section{Kalkmagerrasen}

Kalkmagerrasen sind in Nordwest-Europa meist halbnatürliche Habitate (WallisDeVries et al. 2002) und gehören in Niedersachsen zu der Pflanzenassoziation Gentiano-Koelerietum (Klasse FestucoBrometea). Sie entstanden in der Regel durch extensive Beweidung, zum Teil auch durch Mahd und benötigen regelmäßige Pflegemaßnahmen, um einer zu starken

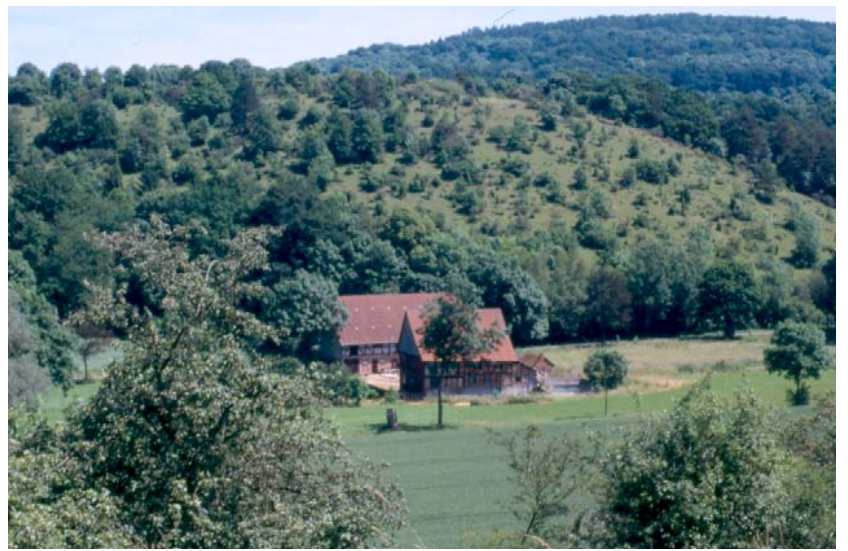

Fig. 2 Kalkmagerrasen "Mühlenberg"

Sukzession vorzubeugen. Durch die Intensivierung der Landwirtschaft sind sie in den letzten Jahrzehnten stark zurückgegangen (WallisDeVries et al. 2002) und gelten in Deutschland als gefährdet (Riecken et al. 1994). Da sie zu den artenreichsten Habitaten Mitteleuropas für Insekten (insbesondere Tagfalter) und Pflanzen gehören (Van Swaay 2002, WallisDeVries et al. 2002), haben der Naturschutz und die Naturschutzforschung großes Interesse an diesem Habitattyp (siehe Beinlich \& Plachter 1995 und den Sonderband von Biological Conservation vom Jahr 2002, Band 104).

\section{ERGEBNISSE}

Die Habitatgröße war der wichtigste Faktor für die Artenvielfalt eines Habitats, während die Habitatisolation in dieser Untersuchungsregion nur eine geringe Rolle für die Artenvielfalt spielte. Isolation wirkte sich aber negativ auf den Genfluss von P. coridon aus. Die Landschaftsstruktur der Umgebung zeigte nur einen signifikanten Einfluss auf die Generalisten unter den Tagfaltern. 
Die Untersuchungen zur zeitlichen Dynamik von Lebensgemeinschaften zeigten, dass die Immigrationsraten von Tagfaltern mit zunehmender Habitatgröße ansteigen, während die Extinktions- und Turnoverraten abnehmen. Die Extinktions- und Turnoverraten der Habitatspezialisten waren im Mittel höher als die der Generalisten und wurden stärker vom Habitatverlust beeinflusst. Die Immigrationsraten waren bei den Generalisten im Mittel höher. Auf den kleineren Untersuchungsflächen war die Bilanz zwischen einwandernden und aussterbenden Arten bei den Habitatspezialisten negativ, das heißt, dass in einem Zeitraum von vier Jahren zwischen 1996 und 2000 auf diesen Flächen die Artenzahl der Habitatspezialisten zurückgegangen ist. Die Habitatisolation hatte keinen signifikanten Einfluss auf Immigrations-, Extinktions- oder Turnoverraten (Kapitel 2).

Bei den Untersuchungen im Jahr 2000 zeigte sich, dass die Größe der Habitatflächen den höchsten Erklärungswert für die Anzahl der Tagfalterarten hatte. Die Größe eines Habitats war auch mit der Artenzahl und Deckung der Blütenpflanzen korreliert, die Habitatsqualitätsfaktoren für Tagfalter darstellen. Eine Trennung des Einflusses von Habitatqualität und Heterogenität von Areal per se- Effekten war deshalb nicht möglich. Die Habitatisolation spielte erneut keine Rolle für die Artenzahl, während mit zunehmender Landschaftsdiversität um die Habitate die Artenzahl, v.a. der Generalisten positiv beeinflusst wurde. Dieser Landschaftseffekt war jedoch skalierungsabhängig und nur für den kleinsten Radius von $250 \mathrm{~m}$ um das Habitat signifikant. Insgesamt reagierten Habitatspezialisten sensibler auf die Habitatgröße (steilere Steigung), Generalisten reagierten stärker auf die Landschaftsstruktur. Dies zeigte sich auch bei der Auswertung der Einzelarten. Die Populationsdichte der Tagfaltergemeinschaften war positiv mit der Habitatgröße korreliert, Isolation und Landschaftsstruktur spielten jedoch keine modifizierende Rolle (Kapitel 3).

Die Artenzahl der Blütenpflanzen auf Kalkmagerrasen nahm ähnlich wie die der Tagfalter mit der Habitatgröße zu. Die Steigung war hierbei jedoch bei Spezialisten nicht höher als bei Generalisten. Für die Anzahl der Pflanzenarten spielten Habitatisolation und Landschaftsstruktur der Umgebung keine Rolle. Analysen mit der gleichen Braun-Blanquet Probengröße auf allen Flächen (= Artendichte) ergaben keinen signifikanten Zusammenhang mit den drei Faktoren Habitatgröße, Isolation und Landschaftsstruktur. Der fehlende Zusammenhang mit der Habitatgröße spricht gegen eine Annahme der Areal per seHypothese (Kapitel 4).

Die Untersuchung der Populationsgenetik von 17 Populationen des Tagfalters Polyommatus coridon am Nordrand seines Verbreitungsgebietes ergab eine generelle Abnahme der genetischen Variabilität gegenüber Populationen aus dem Kernbereich der 
Verbreitung. Die Populationen in der Untersuchungsregion unterschieden sich signifikant voneinander, es existierte jedoch keine isolation by distance Struktur. Populationen der beiden Unterregionen westlich und östlich des Flusses Leine waren genetisch getrennt, es besteht also eine Barriere für den Genfluss. Weder die Populationsgröße des Tagfalters, noch die damit stark korrelierte Habitatgröße oder die Größe der Futterpflanzenpopulation ergaben einen signifikanten Einfluss auf die genetische Diversität. Ansteigende Habitatisolation, als Distanz zur nächsten $P$. coridon Population gemessen, reduzierte jedoch die erwartete Heterozygotie (Kapitel 5).

\section{SCHLUSSFOLGERUNGEN}

Die Untersuchungen zeigen, dass die Habitatgröße der Kalkmagerrasen in der Untersuchungsregion um Göttingen die Artenvielfalt entscheidend beeinflusst, während die Isolation der Habitate für die Artengemeinschaft der Blütenpflanzen und Tagfalter kaum eine Rolle spielt. Der herausragende Effekt der Habitatgröße ist v.a. für die meist gefährdeten Habitatspezialisten entscheidend. Zumindest die Artenzahlen spezialisierter Tagfalter nehmen auf den kleinen Habitatflächen weiter ab. Als Schutzmaßnahme gegen ein Aussterben dieser Arten ist die Erhaltung der größten Kalkmagerrasen unumgänglich. Darüber hinaus sollte aber auch die fortschreitende Verkleinerung der kleinen Habitate verhindert werden, um diese Habitate wenigstens für einzelne Arten noch attraktiv zu halten.

Da die Habitatisolation nur einen geringen Einfluss auf die Artenvielfalt und die Populationsdichten zeigte, sind zum Schutz der Tagfalter- und Pflanzenarten zur Zeit keine zusätzlichen Maßnahmen zum Biotopverbund wie z. B. Trittsteinbiotope notwendig. Die Ausbreitungsfähigkeit der meisten Arten scheint für die Untersuchungsregion somit ausreichend zu sein. Für einzelne Arten kann der Grad der Isolation jedoch einen kritischen Schwellenwert überschritten haben. So ist der Genfluss zwischen den isolierten Habitaten von P. coridon reduziert. Hierbei spielt zwar auch die natürliche Isolation der Populationen auf verinselten Kalkkappen eine Rolle, eine zunehmende Isolation führte hier aber zu verringerter genetischer Diversität. Diese könnte als Folge von Inzuchtdepression zu einer verminderten Populationsfitness führen.

Die Landschaftsstruktur der Umgebung hatte einen signifikanten Einfluss auf die Artenzahl der Tagfaltergeneralisten. Sie stieg mit zunehmender Landschaftsdiversität um die untersuchten Habitate an. Für den Schutz von seltenen, meist spezialisierten Arten spielt die Landschaftsstruktur wohl nur eine untergeordnete Rolle. Landschaftselemente wie z. B. das Leine-Flusstal, mit intensiver Agrarlandschaft und zahlreichen Siedlungen, können auch als 
Dispersionsbarrieren für einen regelmäßigen Genfluss angesehen werden.

Dispersionsfördernde Landschaftselemente könnten hier zu einer besseren Konnektivität zwischen den Habitaten führen.

Hypothesen der Inselbiogeographie konnten teilweise bestätigt werden. Arten-ArealBeziehungen waren generell deutlich, und auch die zeitliche Dynamik zeigte zunehmende Immigrations- und abnehmende Extinktions- und Turnoverraten mit zunehmender Arealgröße. Die höhere trophische Ebene der Tagfalter ist dabei stärker gefährdet als die niedrigere trophische Ebene der Pflanzen. Habitatspezialisten sind zudem stärker gefährdet als Generalisten. Arten-Areal-Beziehungen werden durch zwei Hypothesen erklärt, die Areal per $s e$ - und die Habitatheterogenitäts-Hypothese. Die enge Korrelation zwischen Habitatgröße und Habitatqualität für Tagfalter lässt keine Aussage zu. Die fehlende Korrelation zwischen Artendichte der Blütenpflanzen und Habitatgröße stützt jedoch die HabitatheterogenitätsHypothese.

Die Dispersionsfähigkeit von Arten bzw. Artengruppen bestimmt den Einfluss der Habitatisolation. Da für die untersuchten Tagfalter und Pflanzen keine Auswirkungen der Isolation nachgewiesen werden konnten, waren sie offenbar in der Lage, die Distanzen zwischen den Habitaten zu überwinden. Die Isolation mag jedoch auf die genetische Diversität von spezialisierten Einzelarten einen stärkeren Einfluss haben als auf die Artendiversität.

\section{LITERATUR}

Amos W., Harwood J. (1998) Factors affecting levels of genetic diversity in natural populations. Philosophical Transactions of the Royal Society of London Biological Sciences 353, 177-186.

Asher J., Warren M., Fox R., Harding P., Jeffcoate G., Jeffcoate S. (2001) The millennium atlas of butterflies in Britain and Ireland. Oxford University Press, Oxford, United Kingdom.

Beinlich B., Plachter H. (1995) Ein Naturschutzkonzept für Kalkmagerrasen der Mittleren Schwäbischen Alb (Baden-Württemberg): Schutz, Nutzung und Entwicklung. Beihefte zu den Veröffentlichungen für Naturschutz und Landschaftspflege in Baden-Württemberg 83,1-520.

Bink F.A. (1992) Ecologische Atlas van de Dagvlinders van Noordwest-Europa. Schuyt, Haarem, The Netherlands.

Begon M., Harper J.L., Townsend C.R. (1996) Ecology. Blackwell Science Ltd. Oxford, UK.

Bender D.J., Contreras T.A., Fahrig L. (1998) Habitat loss and population decline: a meta-analysis of the patch size effect. Ecology 79, 517-533.

Bourn N.A.D., Thomas J.A. (2002) The challenge of conserving grassland insects at the margins of their range in Europe. Biological Conservation 104, 285-292. 
Brändle M., Öhlschläger S., Brandl R. (2002) Range sizes in butterflies: correlation across scales. Evolutionary Ecology Research 4, 993-1004.

Bunce R.G.H., Howard D.C. (1990) Species dispersal in agricultural habitats. Belhaven Press, London, UK.

Connor E.F., Courtney A.C., Yoder J.M. (2000) Individuals-area relationships: the relationship between animal population density and area. Ecology 81, 734-748.

Cowley M.J.R., Thomas C.D., Roy D.B., Wilson R.J., Leon-Cortes J.L., Gutierrez D., Bulmann C.R., Quinn R.M., Moss D., Gaston K.J. (2001) Density-distribution relationships in British butterflies. I. The effect of mobility and spatial scale. Journal of Animal Ecology 70, 410-425.

Davies K.F., Margules C.R., Lawrence J.F. (2000) Which traits of species predict population declines in experimental forest fragments? Ecology 81,1450-1461.

De Vries H.H., den Boer P.J., van Dijk T.S. (1996) Ground beetle species in heathland fragments in relation to survival, dispersal, and habitat preference. Oecologia 107, 332-342.

Ebert G., Rennwald E. (1991) Die Schmetterlinge Baden-Württembergs. Band 1, Tagfalter I., Band 2, Tagfalter II. Eugen Ulmer Verlag, Stuttgart, Germany.

Fischer M., Stöcklin J. (1997) Local extinctions of plants in remnants of extensively used calcareous grasslands 1950-1985. Conservation Biology 11, 727-737.

Garve E. (1994) Atlas der gefährdeten Farn- und Blütenpflanzen in Niedersachsen und Bremen. Kartierung 1982 - 1992. Naturschutz und Landschaftspflege in Niedersachsen 30, 1-895.

Gaston K.J. (1994) Rarity. Chapman and Hall, London, UK.

Hanski I. (1999) Metapopulation ecology. Oxford University Press, New York, USA.

Hanski I., Gilpin M.E. (1997) Metapopulation biology: ecology, genetics, and evolution. Academic Press, San Diego, USA.

Hanski I., Singer M.C. (2001) Extinction-colonization dynamics and host-plant choice in butterfly metapopulations. The American Naturalist 158, 341-353.

Hanski I., Simberloff D. (1997) The metapopulation approach, its history, conceptual domain, and application to conservation. Metapopulation biology: ecology, genetics, and evolution. (eds Hanski I., Gilpin M.E.), pp. 5-26. Academic Press, San Diego, USA.

Harrison S., Bruna E. (1999) Habitat fragmentation and large-scale conservation: what do we know for sure? Ecography 22, 225-232.

Holt R.D., Lawton J.H., Polis G.A., Martinez N.D. (1999) Trophic rank and species-area relationship. Ecology 80, 1495-1504.

Jedicke E. (1994) Biotopverbund - Grundlagen und Maßnahmen einer neuen Naturschutzstrategie. Ulmer Verlag, Stuttgart, Germany.

Jedicke E. (1997) Die Roten Listen: gefährdete Pflanzen, Tiere, Pflanzengesellschaften und Biotope in Bund und Ländern. Ulmer Verlag, Stuttgart, Germany. 
Jonsen I.D., Fahrig L. (1997) Response of generalist and specialist insect herbivores to landscape spatial structure. Landscape Ecology 12, 185-197.

Kudrna O. (2002) The distribution atlas of European butterflies. Distribution maps of all species. Oedippus 20, 1-343.

Kruess A., Tscharntke T. (1994) Habitat fragmentation, species loss, and biological control. Science 264, 1581-1584.

Lawton J.H. (1995) Population dynamic principles. Extinction rates (eds Lawton J.H., May R.M.), pp. 147-163. Oxford University Press, Oxford, UK.

Levins R. (1969) Some demographic and genetic consequences of environmental heterogeneity for biological control. Bulletin of the Entomological Society of America 15, 237-240.

Maes D., Van Dyck H. (2001) Butterfly diversity loss in Flanders (north Belgium): Europe's worst case scenario? Biological Conservation 99, 263-276.

MacArthur R.H., Wilson E.O. (1963) An equilibrium theory of insular zoography. Evolution 17, 373387.

MacArthur R.H., Wilson E.O. (1967) The theory of island biogeography. Princeton University Press, Princeton, New Jersey, USA.

Manne L.L., Pimm S.L., Diamond J.M., Reed T.M. (1998) The form of the curves: a direct evaluation of MacArthur \& Wilson's classic theory. Journal of Animal Ecology 67, 784-794.

Mattern H., Wolf R., Mauk J. (1980) Heiden im Regierungsbezirk Stuttgart -Zwischenbilanz im Jahre 1980-. Veröffentlichungen für Naturschutz und Landschaftspflege Baden-Württemberg 51/52, 153-165.

Mattern H., Mauk J., Kübler R. (1992) Die Entwicklung der Heiden im Regierungsbezirk Stuttgart während des letzten Jahrzehnts (1980/1990). Veröffentlichungen für Naturschutz und Landschaftspflege Baden-Württemberg 67, 127-136.

Pimm S.L. (1991) The balance of nature? Ecological issues in the conservation of species and communities. The University of Chicago Press, Chicago, Illinois, USA.

Plachter H. (1991) Naturschutz. UTB 1563, Fischer Verlag, Stuttgart.

Riecken U., Ries U., Ssymank A. (1994) Rote Liste der gefährdeten Biotoptypen der Bundesrepublik Deutschland. Kilda-Verlag, Greven, Germany.

Reich M., Grimm V. (1996) Das Metapopulationskonzept in Ökologie und Naturschutz: Eine kritische Bestandsaufnahme. Zeitschrift für Ökologie und Naturschutz 5, 123-139.

Rosenzweig M.L. (1995) Species diversity in space and time. Cambridge University Press, Cambridge, UK.

Settele J., Feldmann R., Reinhardt R. (1999) Die Tagfalter Deutschlands. Eugen Ulmer Verlag. Stuttgart. 452 S, Germany.

Steffan-Dewenter I., Tscharntke T. (2000) Butterfly community structure in fragmented habitats. Ecology Letters 3, 449-456. 
Thomas C.D., Thomas J.A., Warren M.S. (1992) Distribution of occupied and vacant butterfly habitats in fragmented landscapes. Oecologia, 92, 563-567.

Tscharntke T., Kruess A. (1999) Habitat fragmentation and biological control. Theoretical approaches to biological control. (eds. Hawkins B.A., Cornell H.V.), pp. 190-205. Cambridge University Press, Cambridge, UK.

Tscharntke T., Steffan-Dewenter I., Kruess A., Thies C. (2002a) Characteristics of insect populations on habitat fragments: A mini review. Ecological Research 17, 229-239.

Tscharntke T., Steffan-Dewenter I., Kruess A., Thies C. (2002b) The contribution of small habitat fragments to the conservation of insect communities of grassland-cropland landscape mosaics. Ecological Applications 12, 354-363.

Vandermeer J., Carvajal R. (2001) Metapopulation dynamics and quality of the matrix. The American Naturalist 158, 211-220.

Van Swaay C.A.M. (2002) The importance of calcareous grasslands for butterflies in Europe. Biological Conservation 104, 315-318.

WallisDeVries M.F., Poschlod P., Willems J.H. (2002) Challenges for the conservation of calcareous grasslands in northwestern Europe: integrating the requirements of flora and fauna. Biological Conservation 104, 265-273.

Warren M.S., Hill J.K., Thomas J.A., Asher J., Fox R., Huntley B., Roy D.B., Telfer M.G., Jeffcoate S., Harding P., Jeffcoate G., Willis S.G., Greatorex-Davis J.N., Moss D., Thomas C.D. (2001) Rapid responses of British butterflies to opposing forces of climate and habitat change. Nature 414, 65-69.

Weidemann H.J. (1995) Tagfalter: beobachten und bestimmen. Naturbuch Verlag, Augsburg, Germany.

Wiens J.A. (1997) Metapopulation dynamics and landscape ecology. Metapopulation biology: ecology, genetics, and evolution (eds Hanski I., Gilpin M.E.) pp. 43-62. Academic Press, San Diego, USA.

Whittaker R.J. (1998) Island biogeography. Ecology, Evolution, and Conservation. Oxford University Press, Oxford, UK.

Young A., Boyle T., Brown T. (1996) The population genetic consequences of habitat fragmentation for plants. Trends in Ecology and Evolution 11, 413-418.

Zabel J., Tscharntke T. (1998) Does fragmentation of Urtica habitats affect phytophagous and predatory insects differentially? Oecologia 116, 419-425. 


\title{
Local species immigration, extinction, and turnover of butterflies in relation to habitat area and habitat isolation
}

\begin{abstract}
Temporal dynamics of insect communities in terrestrial habitat fragments have been rarely studied. Here it was tested whether immigration, extinction, and turnover of butterfly species change with area and isolation of 31 calcareous grasslands. The area ranged from 0.03 to 5.14 ha, the isolation index from 2,100 to 86,000 (edge-to-edge distance 55 $1,894 \mathrm{~m})$. In both study years $(1996,2000)$, the total number of individuals $(16,466,15,101)$ and species $(60,54)$ sampled across all sites were similar and number of species increased with area in both years indicating an equilibrium. Rates of extinction (38\% for habitat specialists vs. $20 \%$ for generalists) and turnover (51\% vs. $35 \%$ ) were higher, and rates of immigration (11\% vs. $30 \%$ ) were lower for habitat specialists than for generalists. Extinction and turnover rates decreased with increasing fragment size for both specialist ( $n=25$ species) and generalist $(n=36)$ butterflies, but specialists showed a significantly steeper decrease with increasing fragment size than generalists. Immigration rates increased with area. As a result, species number of habitat specialists declined on small habitats but not on large habitats between 1996 and 2000. No significant impact of habitat isolation on the butterfly community was found. The data suggest that large habitat fragments are of special importance for the conservation of the specialized, most endangered butterfly species. Habitat isolation appears to be less important, as butterflies can cope with the habitat mosaic in our study region.
\end{abstract}

KEYWORDS habitat fragmentation, species-area relationship, specialists, generalists, grasslands

\section{INTRODUCTION}

Habitat fragmentation is one of the major causes for local extinction (Begon et al. 1996), but fragmentation does not affect all species equally (Pimm 1991, Lawton 1995). Rare species (Pimm 1991, Gaston 1994, Lawton 1995), food specialists (Zabel \& Tscharntke 1998, Steffan-Dewenter \& Tscharntke 2000), species with low dispersal abilities (Bunce \& Howard 1990, Lawton 1995, DeVries et al. 1996, Bender et al. 1998), and species with low population densities or high population variability (Pimm 1991, Kruess \& Tscharntke 1994, Lawton 
1995, Zabel \& Tscharntke 1998) are predicted to suffer more from decreasing habitat area than other species. Habitat specialists are typically characterized by a combination of the above-mentioned life history traits (Lawton 1995, Warren et al. 2001, Brändle et al. 2002). Accordingly, habitat specialists have been predicted to be particularly affected by habitat loss and isolation (Thomas et al. 1992, Warren et al. 2002), while generalists, typically characterized by high dispersal abilities and broad food range, may profit from the surrounding landscape (Jonsen \& Fahrig 1997). Although effects of habitat area and isolation on species richness and community structure are well studied (e.g. Wilcox et al. 1986, Baz \& Garcia-Boyero 1995, Steffan-Dewenter \& Tscharntke 2000), extremely few studies have tested the causes of temporal changes in community structure by analysing species immigration, extinction, and turnover (Manne et al. 1998).

Two major theories explain the patterns of immigration, extinction, and turnover. The theory of island biogeography predicts a balance of immigration and extinction of species, with increasing species extinction and turnover and decreasing immigration on small isolated compared to large connected islands (MacArthur \& Wilson 1963, 1967, Rosenzweig 1995, Whittaker 1998). The metapopulation theory is based on the concept of colonization and extinction of local populations coupled by dispersal (Hanski \& Simberloff 1997). Contrary to the theory of island biogeography the concept of metapopulations is based on populations, not on communities. Nevertheless the term metacommunity was introduced recently for communities that are made up of metapopulation dynamics (Gilpin \& Hanski 1991, Holt 1997). Conclusions of both theories are fairly consistent (Hanski \& Simberloff 1997, Whittaker 1998).

Immigration, extinction, and turnover also have important implications for conservation of species and habitats, because they allow not only to consider the status quo, but also to predict future trends. Several studies show metapopulation dynamics of individual insect species (e.g. Hanski \& Singer 2001), but on a community level studies are rare and most have been done on real islands in a more theoretical context (e.g. Toft \& Schoener 1983, Rey 1985). A few recent studies focus on species immigration, extinction, and turnover of plants and birds with different ecological traits in terrestrial habitats. Fischer and Stöcklin (1997) found that local extinction of plant species on calcareous grasslands was higher for habitat specialists, species with a short life cycle, and species with small populations. The importance of ecological traits of birds (habitat specifity, body size, migration ability) in fragmented habitats was recently studied, too (Schmiegelow et al. 1997, Boulinier et al. 2001, Crooks et 
al. 2001). As far as we know, local species immigration, extinction, and turnover have never been calculated for specialist and generalist insect communities on fragmented terrestrial habitats.

Here, we studied temporal dynamics of butterfly communities in relation to habitat area and isolation of calcareous grasslands. The study region in Germany is a human-dominated landscape typically characterized by intensive agricultural land use, affecting on average little more than half of the area, and by sharply contrasted habitat mosaics. In this highly fragmented agricultural landscape, biodiversity conservation is an important issue in landscape management (Tscharntke et al. 2002). Calcareous grasslands rank as the most species-rich habitat for butterflies in Germany and all over Europe (van Swaay 2002), and are considered as severely endangered in Germany (Riecken et al. 1994). In Germany and other European countries the decrease of calcareous grasslands has been extremely high in many regions during the last decades (WallisdeVries et al. 2002). Many butterfly species on calcareous grasslands live as metapopulations in these highly fragmented habitats embedded in a mostly hostile landscape matrix (Thomas \& Hanski 1997). Habitat area and isolation of the remaining calcareous grasslands are therefore considered as a major threat for butterflies (van Swaay 2002). In general, butterfly diversity loss is high in Central and Northern Europe with e.g. $42 \%$ in Suffolk, UK in the last 150 years (Bourn \& Thomas 2002) and 30\% in Flanders, Belgium in the last 100 years (Maes \& Van Dyck 2001). Warren et al. (2002) even fear a further decline of habitat specialists because of habitat destruction and degradation, while generalists might increase with climate changes.

Here immigration, extinction, and turnover of butterfly communities comparing habitat specialists and generalists was analysed. The following predictions were tested comparing two censuses four years apart:

(1) Butterfly species richness increases with habitat area and decreases with habitat isolation in both census years.

(2) The number of immigrating butterfly species is higher and the number going extinct is lower with increasing habitat area and decreasing habitat isolation.

(3) Species turnover of butterfly assemblages decreases with increasing habitat area and decreasing habitat isolation.

(4) More habitat specialist than generalist butterflies will go extinct as habitat area declines and habitat isolation increase. 
(4) More habitat specialist than generalist butterflies will go extinct as habitat area declines and habitat isolation increase.

\section{MATERIALS AND METHODS}

\section{Study region and study sites}

A total of 31 calcareous grasslands around the city of Goettingen in Lower Saxony (Germany) were studied in 1996 (see Steffan-Dewenter \& Tscharntke 2000), and again in 2000 (Fig. 1). Semi-natural calcareous grasslands cover only $0.26 \%$ of the area in the study region and can be sharply delimited from the surrounding landscape. The landscape in the study region is structurally rich with a mosaic of diverse habitat types. Most dominant are arable land (42\%) and different forest habitats (37\%).

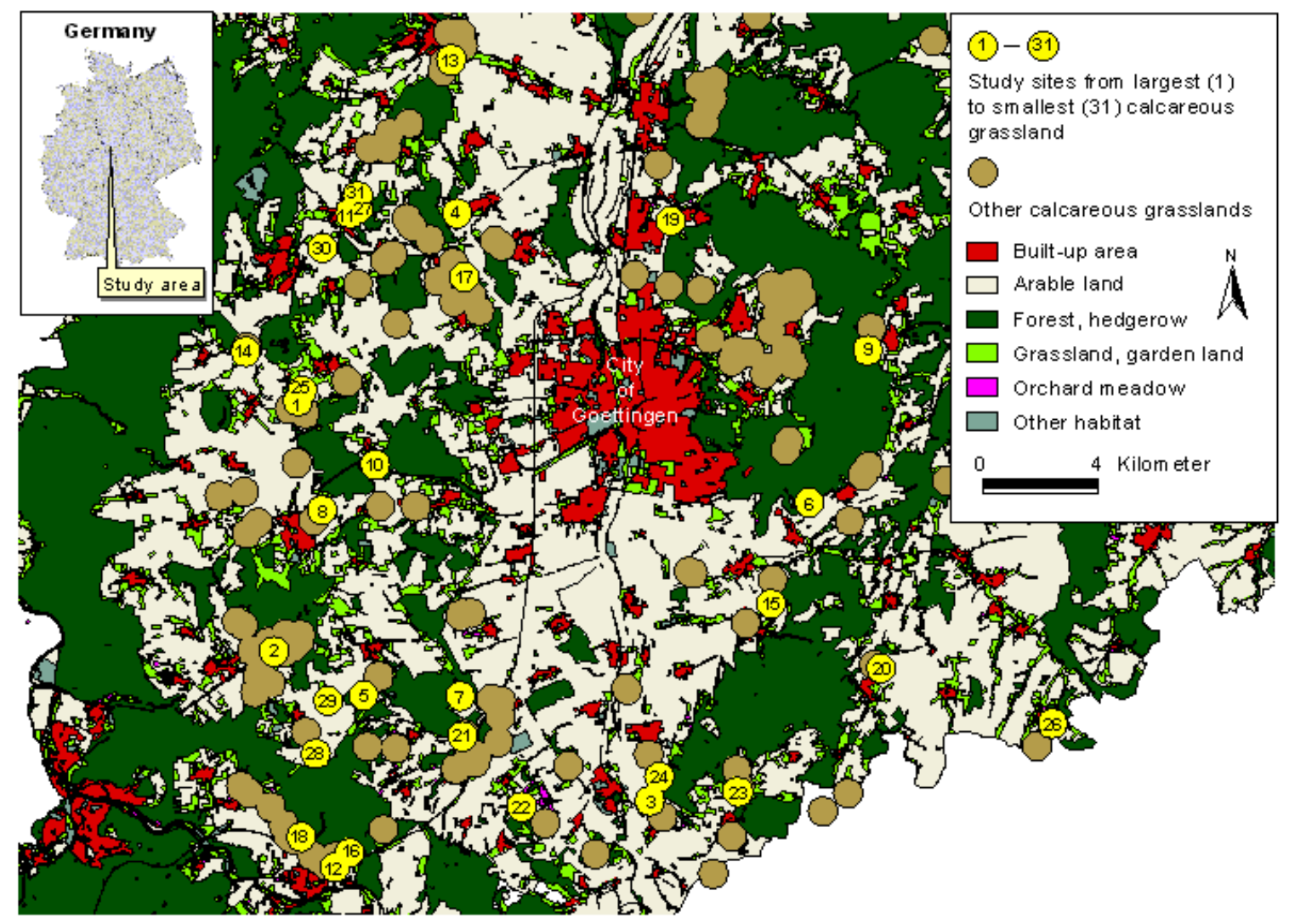

Figure 1 Location of the 31 calcareous grasslands (study sites), shown with a $500 \mathrm{~m}$ radius, around the centre, and all further calcareous grasslands around the city of Göttingen (in the centre of the map).

The 31 study sites were chosen to cover the full gradient of habitat area and isolation in the study region and were neither grazed nor mown during the sampling periods in spring and summer of 1996 and 2000. Low impact management to stop succession and to remove woody bushes were carried out mainly from late summer to winter between the two study years. 
These management activities were divers with non-intensive grazing, mowing or punctually removing of bushes generally only in parts of the grasslands. The influence on butterflies is assumed to be low for mown or grazed grasslands (Dolek \& Geyer 1997) and for short time succession up to a few years (Balmer \& Erhardt 2000).

The area of the 31 study sites was measured with a differential GPS GEOmeter 12L (GEOsat GmbH 1998) and ranged from $300-51,400 \mathrm{~m}^{2}$ (Appendix 1). Habitat isolation (I) of each study site $(i)$ was measured from edge-to-edge with the software "ArcView GIS 3.2 for Windows" (ESRI 1995) on the basis of all known calcareous grasslands in a radius of 8 $\mathrm{km}$ around the 31 study sites using the following formula:

$I=\Sigma e^{-d i j} A_{j}$

where $A_{j}$ is the size (in $\mathrm{m}^{2}$ ) of neighbouring calcareous grasslands and dij the distance (in $\mathrm{km}$ ) from the neighbouring grassland $j$ to the study site $i$. The formula is based on Hanski et al. 1994, and also used by Steffan-Dewenter and Tscharntke (2000). Larger values of $I$ indicate lower isolation than smaller values. Habitat patches at distances larger than $3 \mathrm{~km}$ contribute only marginally to the value of the isolation index. We also tested the distance from the study site to the nearest calcareous grassland as the most simple indicator of isolation (Appendix 1). Isolation index and isolation distance (both always $\log _{10}$ transformed) were correlated (Pearson: $r=-0.445, P=0.012$ ) and gave very similar always non-significant results. Therefore only results from the isolation index are shown in the text.

\section{Butterflies}

Butterflies (Lepidoptera: Hesperioidea and Papilionoidea) and burnets (Lepidoptera: Zygaenidae) were sampled in 1996 (4 June - 7 September) and 2000 (26 April - 24 August) by visual counts along randomised transect walks. The number of species was recorded within a $5 \mathrm{~m}$ corridor when weather conditions were suitable for butterfly activity (for further details see Pollard 1977, Erhardt 1985, Steffan-Dewenter \& Tscharntke 2000). All study sites were sampled five times per study year in a randomised sequence every 3 - 4 weeks within the sampling periods by one person in 1996 and another person in 2000. Transect time per walk varied from 20 - $60 \mathrm{~min}$ in 2000 , depending on the size of the grassland. Transect time was 20 min per transect walk for 11 small grasslands $\left(314-1,326 \mathrm{~m}^{2}\right), 40 \mathrm{~min}$ for 12 intermediate grasslands $\left(1,914-7,887 \mathrm{~m}^{2}\right)$, and $60 \mathrm{~min}$ for 8 large grasslands $(11,528-$ $51,395 \mathrm{~m}^{2}$ ). Similar sampling schedules were used in 1996 (Steffan-Dewenter \& Tscharntke 2000). Data from the five transect walks per year were pooled, resulting in very similar total 
numbers of individuals in both study years (see results). Butterfly counts were conducted in 5 min intervals to calculate accumulation curves. Species identification and nomenclature followed Zub (1996) for burnets and Settele et al. (1999) for butterflies. In the following, butterflies always include burnets.

Because of different weather conditions in 1996 and 2000 there are differences in the sampling periods of both study years. Especially spring species might have been affected, but flight periods of all these species reach mid June (Ebert \& Rennwald 1991) and could be recorded in both years. Nevertheless we marked spring species following Ebert and Rennwald (1991) in the Appendix 2 and calculated all results without them again. The differences with or without spring species were small and generally confirm our results as shown here for three important results. Changes with vs. without spring species: extinction rates-area relationship for specialists $\left(r^{2}=0.457, P<0.0001\right.$ vs. $\left.r^{2}=0.447, P<0.0001\right)$ and for generalists $\left(r^{2}=\right.$ $0.266, P=0.003$ vs. $r^{2}=0.195, P=0.013$ ), see figure $6 \mathrm{~B}$; changes of species numbers of specialists in small habitats between 1996 and 2000 (paired $t$-test: $t=2.39, P=0.038$ vs. $t=$ $3.77, P=0.004)$, see paragraph six of the result section.

We defined butterfly species as specialists $(n=25)$ for calcareous grassland when they were found in Lower Saxony mainly on calcareous grasslands (based on unpublished data from the known distribution of butterflies of Lower Saxony, personal communication Hans Joger "Niedersächsisches Landesamt für Ökologie", Hildesheim). Most of these species (16 species) were also recorded in Zub (1996) and Settele et al. (1999) as calcareous grassland specialists or with strong preferences for this habitat type. However, some habitat specialists are not mentioned in literature as they inhabit additional habitats in other regions of Germany or Europe, but they are restricted to calcareous grasslands in Lower Saxony, because of larval food plant limitation or climatic necessities. Defined generalist butterflies $(n=36)$ were ubiquitous species (12 species) or species with preferences for other habitats ( 24 species) like forests and other grassland types (following Zub 1996 and Settele et al. 1999).

\section{Local species immigration, extinction, and turnover}

There are different ways to calculate immigration, extinction, and turnover (Thornton et al. 1990, Whittaker 1998). We defined immigration as the number of successful local immigration events $(I)$ when species were not detected in a given fragment in 1996, but were present in 2000. We defined extinction as the number of local extinction events $(E)$ when species were found in 1996, but not in 2000. Turnover was calculated as the sum of 
immigration and extinction events divided by two $(T=(I+E) / 2)$. These calculations followed MacArthur and Wilson (1967).

As this measure of immigration, extinction, and turnover depends on the number of species (Robinson \& Quinn 1988, Crooks et al. 2001), many authors use the proportion of (i) immigrated species to the mainland pool species number $(P)$ minus the number of species of the first census $\left(S_{1}\right)$ with $\left(I /\left(P-S_{1}\right)\right)$ for immigration rates (Crooks et al. 2001, see also Manne et al. 1998), (ii) extinct species to the species pool of the first census $\left(E / S_{1}\right)$ for extinction rates (Fischer \& Stöcklin 1997, Crooks et al. 2001), and (iii) the sum of immigrated and extinct species in relation to the species pool of the first $\left(S_{1}\right)$ and second $\left(S_{2}\right)$ census $\left((I+E) /\left(S_{1}\right.\right.$ $\left.+S_{2}\right)$ ) for turnover rates (Diamond 1969, Toft \& Schoener 1983, Schoener \& Spiller 1987, Robinson \& Quinn 1988, Hinsley et al. 1995). We calculated the immigration rates as $I /(P$ $S_{1996}$ ), where the mainland pool $(P)$ is defined as the 61 butterfly species found in total in either survey 1996 or 2000 on all grasslands, and $\left(S_{1996}\right)$ as the species number in 1996. Extinction rates were calculated as $\left(E / S_{1996}\right)$, and turnover rates as $\left.(I+E) /\left(S_{1996}+I\right)\right)$. Turnover calculations with $\left((I+E) /\left(S_{1996}+S_{2000}\right)\right)$ showed almost identical results, but data were not normally distributed. We call absolute immigration, extinction, and turnover in species numbers "events", and relative immigration, extinction, and turnover "rates". To analyze deviation from equilibrium we calculated the difference between the number of immigration and extinction events per habitat $(I-E)$.

\section{Statistical analyses}

Statistical analyses were performed using the software "Statgraphics Plus for Windows 3.0" (Statgraphics 1995). Distributions of all data were normal or close to normal. Most percent data were between $30-70 \%$, so arcsine-square root transformation was not necessary (Sokal $\&$ Rohlf 1995). We calculated simple regressions $\left(P_{\mathrm{R}}\right)$ for relations of area or isolation to species number, immigration, extinction, turnover, and immigration minus extinction events $(I-E)$. The significance of differences between slopes $\left(P_{\mathrm{S}}\right)$ of two regression lines was tested using the advanced regression module of Statgraphics Plus for Windows 3.0, when both regression lines were significant. To compare the means of species numbers of $1996 \mathrm{vs.} 2000$, and immigration, extinction, and turnover for specialists vs. generalists as well as immigration vs. extinction, we used paired $t$-tests $\left(P_{\mathrm{T}}\right)$. The independent variables habitat area and habitat isolation index were always $\log _{10}$ transformed and were not correlated with each other (Pearson: $r=-0.011, P=0.951$ ). To calculate smoothed sample size vs. species numbers 
accumulation curves we randomized data 100 times with the programme EstimateS Version 5 (Colwell 1997). Means are given and shown with standard errors of pooled data from five walks with five-minute sample intervals for each habitat. Arithmetic means \pm standard errors are given in the text.

\section{RESULTS}

In total 61 butterfly species, including seven species of burnets were identified on 31 calcareous grasslands (Appendix 2). In 1996, a total of 16,466 butterfly individuals comprising 60 species were identified. In 2000, we found 15,101 individuals and 54 species. Most species $(n=53)$ were found in both years.

\section{Species-area and species-isolation relationships}

Species-area relationships were calculated separately for 1996 and 2000. In both years highly significant species-area relationships were found (Fig. 2). In 1996, we recorded 14 to 36 species per habitat fragment, in 200011 to 42 species. We could not find any significant difference in slopes of the regression lines, or in butterfly species numbers between 1996 and 2000 (Fig. 2). Also slopes of specialist $\left(F=2.57, P_{\mathrm{S}}=0.114\right)$ and generalist $\left(F=0.59, P_{\mathrm{S}}=\right.$ $0.445)$ butterflies did not significantly differ between the two years as well as species numbers of specialist $\left(t=1.26, P_{\mathrm{T}}=0.217\right)$ and generalist $\left(t=-1.43, P_{\mathrm{T}}=0.163\right)$ butterflies. We could not find significant relations between species numbers and habitat isolation in both study years (1996: $\left.F=0.82, r^{2}=0.028, P_{\mathrm{R}}=0.371 ; 2000: F=0.17, r^{2}=0.006, P_{\mathrm{R}}=0.680\right)$.

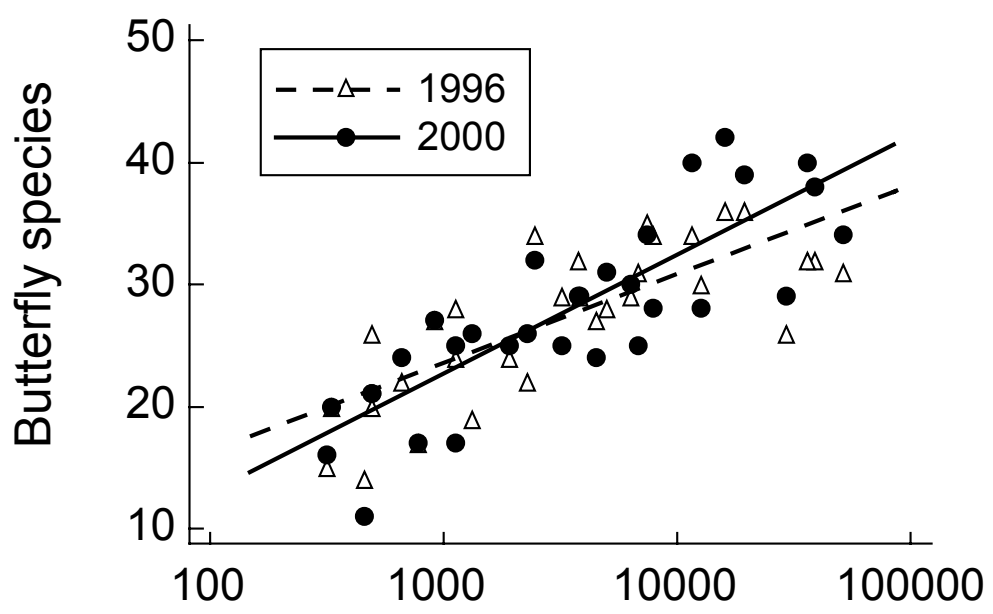

Figure 2 Relationship between the number of butterfly species and grassland area ( $n=31$ fragments) in 1996 and 2000. 1996: $\mathrm{y}=1.69+$ $7.23 \log _{10} \mathrm{x}, F=40.37, r^{2}=0.582$, $P_{\mathrm{R}}<0.0001 ; 2000: \mathrm{y}=-6.28+9.58$ $\log _{10} \mathrm{x}, F=62.48, r^{2}=0.683, P_{\mathrm{R}}<$ 0.0001. Comparison of regressions: Slopes: $F=2.00, P_{\mathrm{S}}=0.163$. Paired $t$-test: $t=-0.42, P_{\mathrm{T}}=0.678$.

Habitat area $\left(\mathrm{m}^{2}\right)$ 
Accumulation curves of butterfly species numbers vs. sample size asymptote in 2000 for small, intermediate, and large grasslands (Fig. 3), indicating sufficient sample size for all study sites. Accumulation curves for the same grasslands in 1996 are shown in SteffanDewenter and Tscharntke (2000).

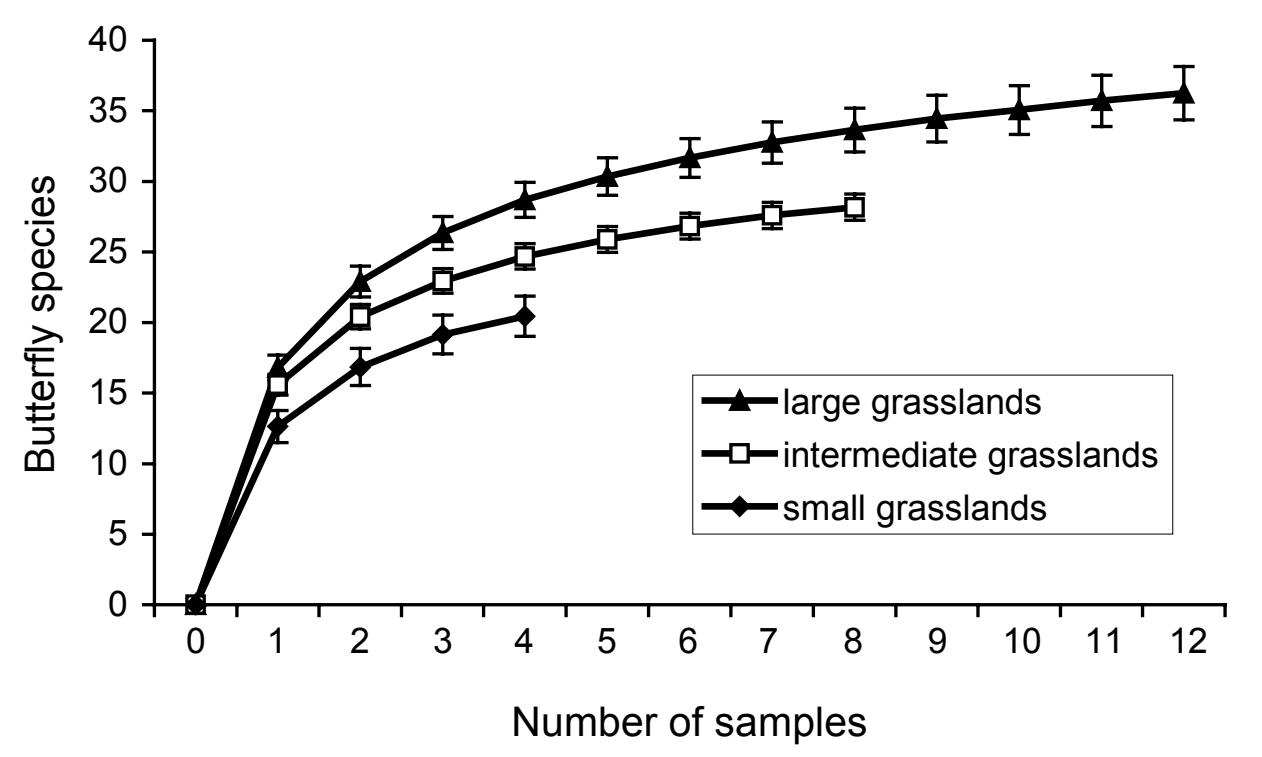

Figure 3 Species accumulation curves for butterfly species in the year 2000 with number of samples: large grasslands $(n=8)$, intermediate grasslands $(n=12)$, and small grasslands $(n=11)$. Each sample is a pooled 25 min interval (five transect minutes of all five transect walks). Shown are arithmetic means with standard errors. Data were smoothed with 100 times randomisation with the program EstimateS, Version 5 (Colwell 1997).

\section{Immigration, extinction, and turnover events}

For all butterfly species the number of immigration events marginally significantly increased with habitat area, as predicted in our hypothesis, whereas extinction and turnover events did not correlate with habitat area (Table 1). The number of immigration events of specialist species $(n=25)$ was positively correlated with habitat area, but not for generalist $(n=36)$ butterflies. The number of local extinction events did not correlate with habitat area for specialists or generalists, while the number of turnover events of species was positively correlated with habitat area for specialists, but not for generalists (Table 1). 
Table 1: Number of immigration $(I)$, and extinction $(E)$ events, and total species turnover $(T)$ of butterfly species (between 1996 and 2000) versus grassland area in $\mathrm{m}^{2}(n=31$ fragments); all butterflies (61 species), specialists $(25$ species) and generalists (36 species).

\begin{tabular}{llllcc} 
Ecological groups & Regression line & $F$ & $r^{2}$ & $P$ & $\begin{array}{c}\text { Mean number Standard } \\
\text { of species }\end{array}$ \\
\hline
\end{tabular}

\begin{tabular}{|c|c|c|c|c|c|c|c|c|}
\hline \multicolumn{9}{|l|}{ Species immigration: } \\
\hline All butterfly species & $y=1.73+1.34 \log _{10} x$ & 2.95 & 0.092 & 0.096 & 6.45 & 0.52 & 0 & 11 \\
\hline Specialists & $y=-2.60+1.23 \log _{10} x$ & 12.00 & 0.293 & 0.002 & 1.74 & 0.27 & 0 & 6 \\
\hline Generalists & $y=4.32+0.11 \log _{10} x$ & 0.03 & 0.001 & 0.866 & 4.71 & 0.40 & 0 & 9 \\
\hline \multicolumn{9}{|l|}{ Species extinction: } \\
\hline All butterfly species & $y=9.70-1.01 \log _{10} x$ & 1.89 & 0.061 & 0.180 & 6.13 & 0.48 & 2 & 13 \\
\hline Specialists & $y=3.02-0.22 \log _{10} x$ & 0.32 & 0.011 & 0.579 & 2.26 & 0.25 & 0 & 7 \\
\hline Generalists & $y=6.67-0.79 \log _{10} x$ & 2.22 & 0.071 & 0.147 & 3.87 & 0.35 & 0 & 9 \\
\hline \multicolumn{9}{|l|}{ Species turnover: } \\
\hline All butterfly species & $y=5.71+0.16 \log _{10} x$ & 0.11 & 0.004 & 0.747 & 6.29 & 0.32 & 2 & 9 \\
\hline Specialists & $y=0.21+0.51 \log _{10} x$ & 5.07 & 0.149 & 0.032 & 2.00 & 0.15 & 0.5 & 4 \\
\hline Generalists & $y=5.50-0.34 \log _{10} x$ & 0.85 & 0.028 & 0.365 & 4.29 & 0.24 & 1.5 & 7.5 \\
\hline
\end{tabular}

Neither specialists $\left(t=-1.26, P_{\mathrm{T}}=0.217\right)$ nor generalists $\left(t=1.43, P_{\mathrm{T}}=0.163\right)$, nor all butterflies $\left(t=0.42, P_{\mathrm{T}}=0.678\right)$ showed a significant difference between the number of immigration and extinction events resulting in equilibrium of all species over all habitats. However, most of the habitats were not in equilibrium, as small sites had more extinction than immigration events, and large sites had more immigration than extinction events calculated as $(I-E)$ for all butterflies $\left(\mathrm{y}=-7.97+2.35 \log _{10} \mathrm{x}, F=4.28, r^{2}=0.129, P_{\mathrm{R}}=0.048\right)$ and specialists, but not for generalists (Fig 4).

Paired $t$-tests of species numbers 1996 vs. 2000 separately for small $(n=11)$, intermediate $(n=12)$, and large habitats $(n=8)$ revealed a significant increase in species numbers for all butterflies in large habitats $\left(t=-3.77, P_{\mathrm{T}}=0.007\right)$, but no effect on intermediate $\left(t=1.42, P_{\mathrm{T}}=0.184\right)$ and small habitats $\left(t=0.46, P_{\mathrm{T}}=0.652\right)$. Separate analysis for specialists revealed a significant decrease of specialists in small habitats $\left(t=2.39, P_{\mathrm{T}}=\right.$ $0.038)$, but no effect on intermediate $\left(t=1.02, P_{\mathrm{T}}=0.331\right)$ and large habitats $\left(t=-1.37, P_{\mathrm{T}}=\right.$ $0.214)$. Species numbers of generalists increased in large habitats $\left(t=-2.86, P_{\mathrm{T}}=0.024\right)$, but 
no effect was found on intermediate $\left(t=0.92, P_{\mathrm{T}}=0.375\right)$ and small habitats $\left(t=-0.80, P_{\mathrm{T}}=\right.$ 0.443).

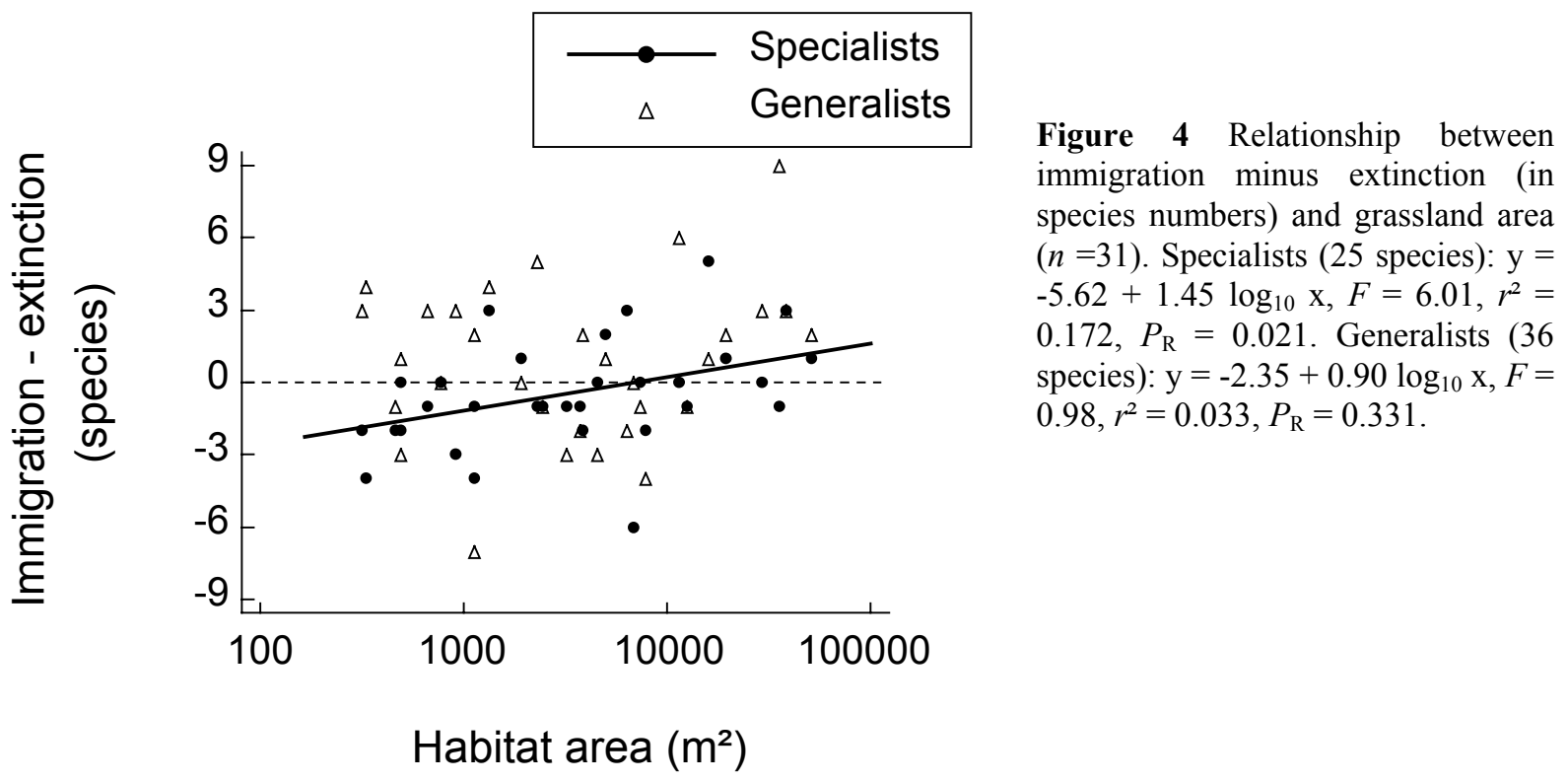

Habitat isolation neither showed a significant relation to the number of immigration events (all butterflies: $F=0.78, r^{2}=0.026, P_{\mathrm{R}}=0.385$; specialists: $F=0.75, r^{2}=0.025, P_{\mathrm{R}}=0.395$; generalists: $F=0.30, r^{2}=0.010, P_{\mathrm{R}}=0.585$ ), extinction events (all butterflies: $F=0.00, r^{2}<$ 0.001, $P_{\mathrm{R}}=0.967$; specialists: $F=0.01, r^{2}<0.001, P_{\mathrm{R}}=0.909$; generalists: $F=0.00, r^{2}<$ $0.001, P_{\mathrm{R}}=0.982$ ) or turnover events (all butterflies: $F=0.56, r^{2}=0.019, P_{\mathrm{R}}=0.460$; specialists: $F=0.71, r^{2}=0.024, P_{\mathrm{R}}=0.407$; generalists: $F=0.20, r^{2}=0.007, P_{\mathrm{R}}=0.656$ ), nor to $I-E$ (all butterflies: $F=0.32, r^{2}=0.011, P_{\mathrm{R}}=0.579$; specialists: $F=0.24, r^{2}=0.008, P_{\mathrm{R}}=$ 0.629; generalists: $F=0.16, r^{2}=0.005, P_{\mathrm{R}}=0.697$ ).

\section{Immigration, extinction, and turnover rates}

Immigration rates were on average $19.94 \pm 1.93 \%$, and increased significantly with increasing habitat area (Fig 5A). Extinction rates were on average $23.70 \pm 2.09 \%$ and decreased significantly with increasing habitat area (Fig 5B). Average turnover rates between 1996 and 2000 were $38.27 \pm 2.05 \%$ and were negatively related to habitat area (Fig 5C).

Average immigration rates between 1996 and 2000 for specialists were $10.78 \pm 1.84 \%$ and for generalists $29.88 \pm 2.51 \%$. Immigration rates of specialists and generalists were positively correlated to habitat area (Fig 6A). Immigration rates of generalists were 
significantly higher than these of specialists, but no differences in slopes were found (Fig 6A). Average extinction rates between 1996 and 2000 for specialists were $38.10 \pm 5.05 \%$ and for generalists $19.80 \pm 1.82 \%$. Extinction rates of both specialists and generalists were negatively correlated to habitat area (Fig 6B). Extinction rates of specialists were significantly higher than those of generalists and had a steeper slope (Fig 6B). Average turnover rates between 1996 and 2000 for specialists were $50.86 \pm 4.20 \%$ and for generalists $34.97 \pm 1.94$ $\%$. Turnover rates of specialists and generalists were negatively related to habitat area (Fig 6C). Turnover rates for specialists were significantly higher than for generalists and showed a steeper slope (Fig 6C).
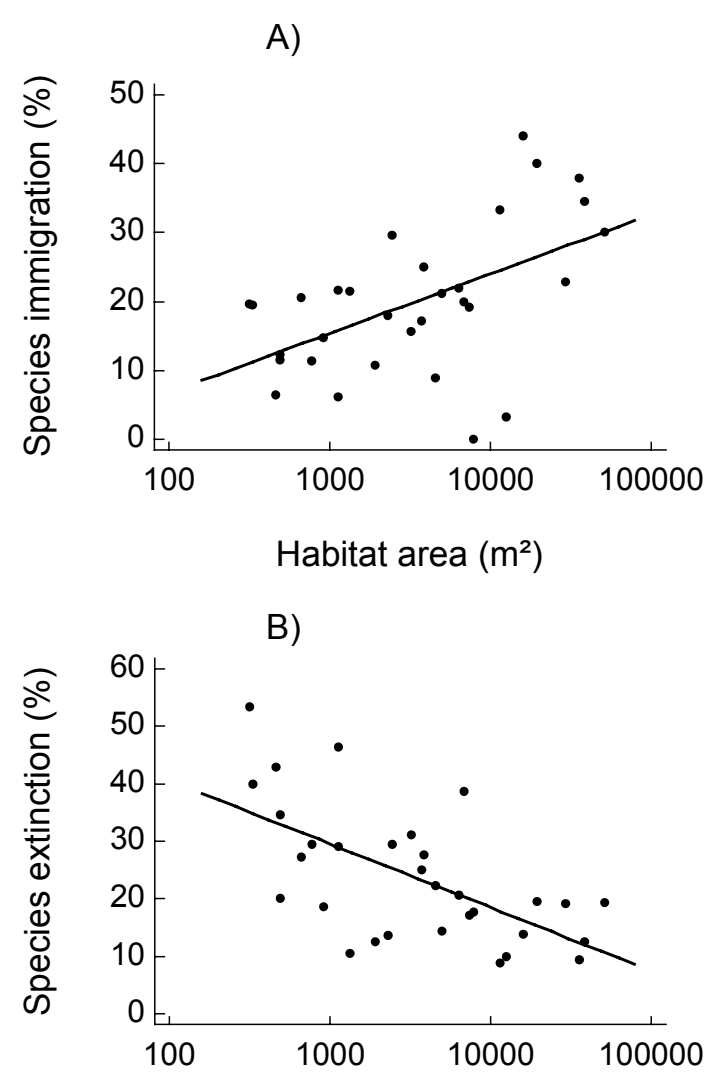

Habitat area $\left(\mathrm{m}^{2}\right)$

C)

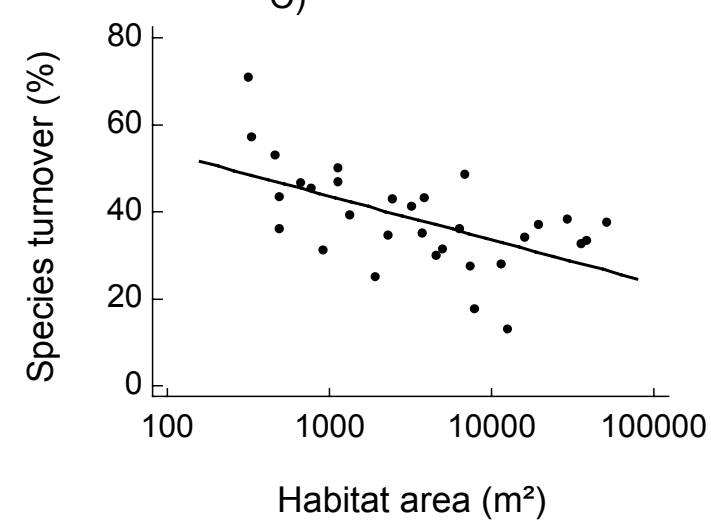

Figure 5 Relationship between species immigration $(\%)$, extinction $(\%)$, and turnover $(\%)$ and grassland area $(n=31)$ between 1996 and 2000 for all butterfly species.

A) Species immigration: $\mathrm{y}=-10.52+8.63 \log _{10}$ $\mathrm{x}, F=11.00, r^{2}=0.275, P_{\mathrm{R}}=0.003$.

B) Species extinction: $\mathrm{y}=62.69-11.05 \log _{10} \mathrm{x}, F$ $=18.08, r^{2}=0.384, P_{\mathrm{R}}=0.0002$.

C) Species turnover: $\mathrm{y}=73.59-10.01 \log _{10} \mathrm{x}, F$ $=14.17, r^{2}=0.328, P_{\mathrm{R}}=0.008$. 


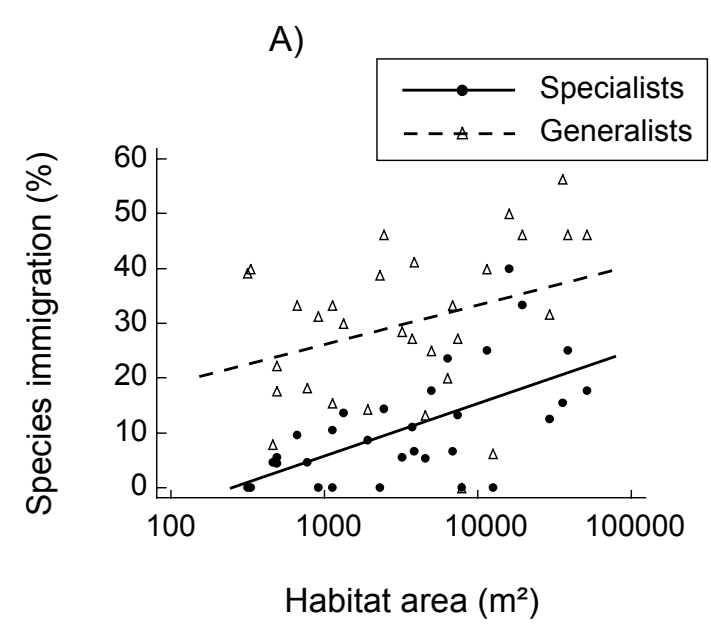

B)

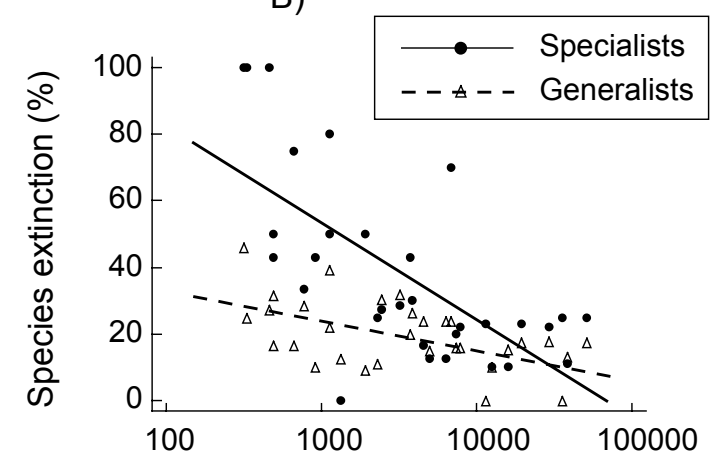

Habitat area $\left(\mathrm{m}^{2}\right)$

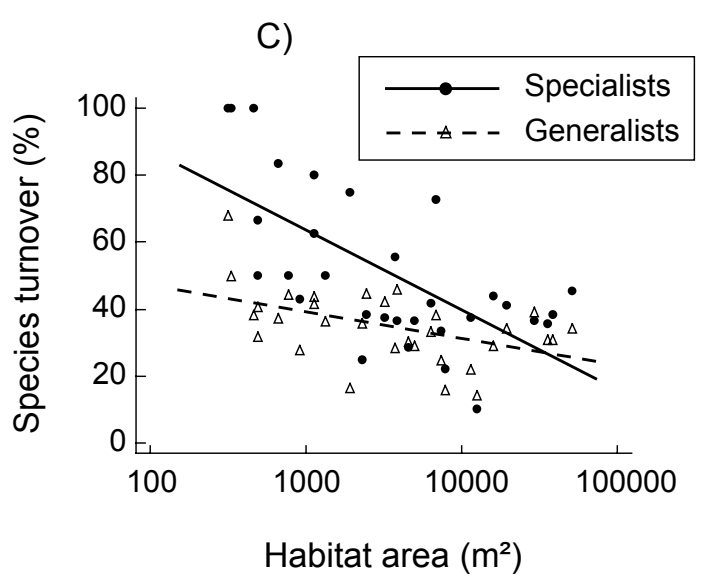

Figure 6 Relationship between species immigration (\%), extinction (\%), and turnover (\%) and grassland area $(n=31)$ between 1996 and 2000 for specialist and generalist butterflies.

A) Species immigration of specialists $(25$ species): $\mathrm{y}=-22.75+9.50 \log _{10} \mathrm{x}, F=16.90, r^{2}=$ $0.368, P_{\mathrm{R}}=0.0003$. Species immigration of generalists ( 36 species): $\mathrm{y}=4.36+7.23 \log _{10} \mathrm{x}, F$ $=3.75, r^{2}=0.114, P_{\mathrm{R}}=0.063$. Comparison of regressions: Slopes: $F=0.27, P_{\mathrm{S}}=0.607$. Paired $t$-test: $t=-8.72, P_{\mathrm{T}}<0.0001$.

B) Species extinction of specialists ( 25 species): $\mathrm{y}$ $=140.96-29.15 \log _{10} \mathrm{x}, F=24.41, r^{2}=0.457, P_{\mathrm{R}}$ $<0.0001$. Species extinction of generalists $(36$ species): $\mathrm{y}=48.15-8.03 \log _{10} \mathrm{x}, F=10.54, r^{2}=$ $0.266, P_{\mathrm{R}}=0.003$. Comparison of regressions: Slopes: $F=10.89, P_{\mathrm{S}}=0.002$. Paired $t$-test: $t=$ $4.17, P_{\mathrm{T}}=0.0002$.

C) Species turnover of specialists (25 species): y $=134.16-23.61 \log _{10} \mathrm{x}, F=22.18, r^{2}=0.433, P_{\mathrm{R}}$ $=0.0001$. Species turnover of generalists $(36$ species): $\mathrm{y}=63.38-8.05 \log _{10} \mathrm{x}, F=8.94, r^{2}=$ $0.236, P_{\mathrm{R}}=0.006$. Comparison of regressions: Slopes: $F=7.47, P_{\mathrm{S}}=0.008$. Paired $t$-test: $t=$ $4.50, P_{\mathrm{T}}=0.0001$.

Habitat isolation showed no significant relation to rates of immigration (all butterflies: $F=$ $0.28, r^{2}=0.009, P_{\mathrm{R}}=0.604$; specialists: $F=0.32, r^{2}=0.011, P_{\mathrm{R}}=0.578$; generalists: $F=$ 0.16, $r^{2}=0,005, P_{\mathrm{R}}=0.694$ ), extinction (all butterflies: $F=0.40, r^{2}=0.014, P_{\mathrm{R}}=0.533$; specialists: $F=0.02, r^{2}<0.001, P_{\mathrm{R}}=0.887$; generalists: $\left.F=0.36, r^{2}=0.012, P_{\mathrm{R}}=0.553\right)$ or turnover (all butterflies: $F=1.43, r^{2}=0.047, P_{\mathrm{R}}=0.241$; specialists: $F=0.50, r^{2}=0.017, P_{\mathrm{R}}$ $=0.484$; generalists: $\left.F=1.12, r^{2}=0.037, P_{\mathrm{R}}=0.299\right)$. 


\section{DISCUSSION}

In this study we tested the importance of habitat area and habitat isolation for immigration, extinction, and turnover of butterfly species on calcareous grasslands. The results support general predictions of the theory of island biogeography and uncover possible future trends in species richness and community structure, which have important implications for conservation management.

\section{Biogeography and theory}

The decreasing immigration rates, and increasing extinction and turnover rates with increasing habitat area that we found are in support of theory (MacArthur \& Wilson 1963, 1967). Generally, habitat specialists supported the theory better than generalists because of stronger effects (steeper slopes). Increasing immigration rates (Crooks et al. 2001), decreasing extinction rates (Boulinier et al. 2001, Crooks et al. 2001) and turnover rates (Hinsley et al. 1995, Schmiegelow et al. 1997, Boulinier et al. 2001, Mason 2001) were also found for bird communities. However predictions for immigration, extinction and turnover were originally made for changes in absolute species numbers (events) and not rates (MacArthur \& Wilson 1963, 1967). We found positive relations between immigration events and habitat area only for specialists thereby confirming the theory, but we failed to confirm predictions for extinction and turnover events. While Toft and Schoener (1983) could confirm the theory at least for immigration and extinction events of spider communities on real islands, many authors did not find decreasing turnover events with increasing habitat area (Toft \& Schoener 1983, Robinson \& Quinn 1988, Hinsley et al. 1995, Mason 2001).

Neither number of events nor rates of immigration, extinction and turnover showed significant trends with habitat isolation in our study, while Toft and Schoener (1983) found more extinction events and less immigration events on isolated islands, confirming the theory (MacArthur \& Wilson 1963, 1967). Turnover rates for birds were found to be higher in isolated fragments (Schmiegelow et al. 1997), whereas Crooks et al. (2001) found correlations of immigration and extinction rates only with habitat area and age, but like us not with isolation. The fairly good connected grasslands in our study region, and the strong dispersal abilities of butterflies might act against strong isolation effects and an improvement of theory.

We are aware of the difficulties to test predictions of island biogeography on terrestrial habitat patches for mobile species. Cryptoturnover, where species might become extinct and reimmigrate within the four-year time period is possible, but should affect all habitat 
fragments equally. Pseudoturnover may occur when censuses are incomplete and information on breeding status are inadequate (Whittaker 1998). However, in this study sample size species number accumulation curves asymptote in both years 1996 (Steffan-Dewenter \& Tscharntke 2000) and 2000 (see results), suggesting an appropriate sample size in all fragments. At least habitat specialists spend most of their life on calcareous grasslands (even on small patches), and only few generalist butterflies may have been recorded because of flower visitation only. Immigration, extinction and turnover are dependent on population size of each species, like reported from Toft and Schoener (1983), Schoener and Spiller (1987) and Crooks et al. (2001) for extinction. Rescue effects or source-sink dynamics may also affect extinction dynamics. The survey 1996 began later than 2000, resulting in the more frequent detection of some spring species in 2000. This may have enhanced the percentage for species turnover, but there is no reason to expect area-dependent changes. However, separate calculations without spring species show very similar results. In conclusion there might be some side effects for the comparison of the two study years, but area- or isolation-dependent patterns and the differences between specialists and generalists are not affected by these possible sampling errors.

\section{Conclusions for conservation}

We found higher extinction and turnover rates, but lower immigration rates for specialists than generalists. This is in support of previous studies, where extinction rates were higher for habitat specialist compared to generalist plants (Fischer \& Stöcklin 1997) and birds (Boulinier et al. 2001). Boulinier et al. (2001) also found higher turnover rates for specialists vs. generalists. As these results indicate a higher risk of local extinction for habitat specialists than generalists, conservation efforts should focus on specialists.

In both study years the total number of individuals and species sampled across all sites were similar, but species richness of specialists decreased in the smallest habitats, while that of generalists increased in the large habitats. The non-equilibrium for specialists in small habitats might have been caused by falling below minimum habitat size for species survival. Extinction debt of species in these habitats might even lead to further future extinctions. Habitat specialist butterflies are known to suffer more from habitat loss than generalists (Warren et al. 2001), as they have no possibility to survive in adjacent vegetation. In our study species numbers of generalists increased significantly in the largest habitats from 1996 
to 2000. Reasons for that remain speculative, but may be related to the general increase of generalists due to climate change as shown for butterflies in UK (Warren et al. 2001).

A species-area relationship for butterflies was found, as shown before by Wilcox et al. (1986) for mountains, Baz and Garcia-Boyero (1995) for forest fragments and SteffanDewenter and Tscharntke (2000) for the same calcareous grasslands in 1996. Immigration, extinction, and turnover are also mainly affected by habitat area pointing out the overriding importance of large habitats. Contrary to predictions, we did not find any effect of isolation on immigration, extinction, turnover or species richness on the butterfly community. However, Thomas et al. (2001) consider habitat isolation and habitat quality as major factors for the occurrence and conservation of three butterfly species, but not habitat area. In a similar study from Thomas et al. (1992), four butterfly species were affected by habitat isolation, and two of them also by habitat area. The difference to our results may be explained (i) by the greater range of habitat isolation in their study region (UK) compared to the relatively low isolation in our region (see Appendix 1), (ii) by the selection of the most susceptible species in their studies compared to effects on the whole butterfly community in our study. We are not aware of any study showing negative effects of isolation on species richness of butterfly communities (Wilcox et al. 1986, Baz \& Garcia-Boyero 1995, SteffanDewenter \& Tscharntke 2000). Thus, population studies for certain species cannot be generalized for the whole community. In our region, the butterflies appeared to be mobile enough to cope with the degree of habitat connectivity. Therefore management plans should focus on the remaining grasslands, not necessarily on creation of stepping stone habitats. However, the quality of the matrix adjacent to the target habitats may be also important for dispersal and may cause landscape-specific differences in the effects of habitat fragmentation (Wiens 1997, Vandermeer \& Carvajal 2001).

In any case, destruction of calcareous grasslands and fragmentation of the remaining grassland area during the last century resulted in many small habitats with reduced species richness. For conservation management it is important to take into account that the number of habitat specialists decrease in small habitat fragments. As many studies on changing patterns in biodiversity do not take into account temporal changes they may underestimate the role of the very large calcareous grasslands, as only large habitats will guarantee reduced extinction and increased immigration rates of the specialized, most endangered species. 
ACKNOWLEDGEMENTS We greatly thank Raphael K. Didham, Robert Ewers, Markus Fischer, Fred Gould, Robert D. Holt, Alexandra-Maria Klein, Andreas Kruess, Martin Schmidt, and David A. Spiller for very helpful comments on the manuscript. We also thank Reinhard Altmüller, Hans Joger, Thomas Meineke and Bertram Preuschoff for their expert advice. Financial support came from the German Science Foundation (Deutsche Forschungsgemeinschaft).

\section{REFERENCES}

Balmer, O., Erhardt A. (2000) Consequences of succession on extensively grazed grasslands for Central European butterfly communities: rethinking conservation practices. Conservation Biology 14, 746-757.

Baz, A., Garcia-Boyero, A. (1995) The effects of forest fragmentation on butterfly communities in central Spain. Journal of Biogeography 22, 129-140.

Begon, M., Harper, J.L., Townsend, C.R. (1996) Ecology. Blackwell Science Ltd. Oxford, UK.

Bender, D.J., Contreras, T.A., Fahrig, L. (1998) Habitat loss and population decline: a meta-analysis of the patch size effect. Ecology 79, 517-533.

Boulinier, T., Nichols, J.D., Hines, J.E., Sauer, J.R., Flather, C.H., Pollock, K.H. (2001) Forest fragmentation and bird community dynamics: inference at regional scales. Ecology 82, 11591169.

Bourn, N.A.D., Thomas, J.A. (2002) The challenge of conserving grassland insects at the margins of their range in Europe. Biological Conservation 104, 285-292.

Brändle, M., Öhlschläger, S., Brandl R (2002) Range sizes in butterflies: correlation across scales. Evolutionary Ecology Research 4, 993-1004

Bunce, R.G.H., Howard, D.C. (1990) Species dispersal in agricultural habitats. Belhaven Press, London, UK.

Colwell, R.K. (1997) EstimateS: Statistical estimation of species richness and shared species from samples. Version 5. User's Guide and application published at: http://viceroy.eeb.uconn.edu/estimates.

Crooks, K.R., Suarez, A.V., Bolger, D.T., Soule, M.E. (2001) Extinction and colonization of birds on habitat islands. Conservation Biology 15, 159-172.

De Vries, H.H., den Boer, P.J., van Dijk, T.S. (1996) Ground beetle species in heathland fragments in relation to survival, dispersal, and habitat preference. Oecologia 107, 332-342.

Diamond, J.M. (1969) Avifaunal equilibria and species turnover rates on the channel islands of California. Proceedings of the National Academy of Science, US 64, 57-63.

Dolek, M., Geyer, A. (1997) Influence of management on butterflies of rare grassland ecosystems in Germany. Journal of Insect Conservation 1, 125-130. 
Ebert, G., Rennwald, E. (1991) Die Schmetterlinge Baden-Württembergs. Band 1, Tagfalter I., Band 2, Tagfalter II. Eugen Ulmer Verlag, Stuttgart, Germany.

Erhardt, A. (1985) Wiesen und Brachland als Lebensraum für Schmetterlinge. Eine Fallstudie im Tavetsch (GR). Birkhäuser Verlag, Basel, Switzerland.

ESRI (1995) ArcView GIS for Windows, Version 3.2. ESRI, Redlands, CA, USA.

Fischer, M., Stöcklin, J. (1997) Local extinctions of plants in remnants of extensively used calcareous grasslands 1950-1985. Conservation Biology 11, 727-737.

Gaston, K.J. (1994) Rarity. Chapman and Hall, London, UK.

GEOsat GmbH (1998) GEOlink Version 1.46. Wuppertal, Germany.

Gilpin, M.E., Hanski, I. (1991) Metapopulation dynamics: empirical and theoretical investigations. Academic Press, London, UK.

Hanski, I., Kuussaari, M., Nieminen, M. (1994) Metapopulation structure and migration in the butterfly Melitaea cinxia. Ecology 75, 747-762.

Hanski, I.,, Simberloff, D. (1997) The metapopulation approach, its history, conceptual domain, and application to conservation. Metapopulation biology: ecology, genetics, and evolution. (eds Hanski I., Gilpin M.E.), pp. 5-26. Academic Press, San Diego, USA.

Hanski, I., Singer, M.C. (2001) Extinction-colonization dynamics and host-plant choice in butterfly metapopulations. The American Naturalist 158, 341-353.

Hinsley, S.A., Bellamy, P.E., Newton, I. (1995) Bird species turnover and stochastic extinction in woodland fragments. Ecography 18, 41-50.

Holt, R.D. (1997) From metapopulation dynamics to community structure. Metapopulation biology: ecology, genetics, and evolution. (eds Hanski I., Gilpin M.E.), pp. 149-164. Academic Press, San Diego, USA.

Jonsen, I.D., Fahrig, L. (1997) Response of generalist and specialist insect herbivores to landscape spatial structure. Landscape Ecology 12, 185-197.

Kruess, A., Tscharntke, T. (1994) Habitat fragmentation, species loss, and biological control. Science 264, 1581-1584.

Lawton, J.H. (1995) Population dynamic principles. Extinction rates (eds Lawton J.H., May R.M.), pp. 147-163. Oxford University Press, Oxford, UK.

Maes, D., Van Dyck, H. (2001) Butterfly diversity loss in Flanders (north Belgium): Europe's worst case scenario? Biological Conservation 99, 263-276.

MacArthur, R.H., Wilson, E.O. (1963) An equilibrium theory of insular zoography. Evolution 17, 373387.

MacArthur, R.H., Wilson, E.O. (1967) The theory of island biogeography. Princeton University Press, Princeton, New Jersey, USA. 
Manne, L.L., Pimm, S.L., Diamond, J.M., Reed, T.M. (1998) The form of the curves: a direct evaluation of MacArthur \& Wilson's classic theory. Journal of Animal Ecology, 67, 784-794.

Mason, C.F. (2001) Woodland area, species turnover and the conservation of bird assemblages in lowland England. Biodiversity and Conservation 10, 495-510.

Pimm, S.L. (1991) The balance of nature? Ecological issues in the conservation of species and communities. The University of Chicago Press, Chicago, Illinois, USA.

Pollard, E. (1977) A method for assessing changes in the abundance of butterflies. Biological Conservation 12, 115-134.

Rey, J.R. (1985) Insular ecology of salt marsh arthropods: species level patterns. Journal of Biogeography 12, 97-107.

Riecken, U., Ries, U., Ssymank, A. (1994) Rote Liste der gefährdeten Biotoptypen der Bundesrepublik Deutschland. Kilda-Verlag, Greven, Germany.

Robinson, G.R., Quinn, J.F. (1988) Extinction, turnover and species diversity in an experimentally fragmented California annual grassland. Oecologia 76, 71-82.

Rosenzweig, M.L. (1995) Species diversity in space and time. Cambridge University Press, Cambridge, UK.

Schmiegelow, F.K.A., Machtans, C.S., Hannon, S.J. (1997) Are boreal birds resilient to forest fragmentation? An experimental study of short-term community responses. Ecology 78, 19141932.

Schoener, T.W., Spiller, D.A. (1987) High population persistence in a system with high turnover. Nature 330, 474-477.

Settele, J., Feldmann, R., Reinhardt, R. (1999) Die Tagfalter Deutschlands. Eugen Ulmer Verlag, Stuttgart, Germany.

Sokal, R.R., Rohlf, F. (1995) Biometry. Freeman, NY, USA.

Statgraphics (1995) Statgraphics plus for Windows, Version 3.0. Manugistics, Inc, Rockville, MD, USA.

Steffan-Dewenter, I., Tscharntke, T. (2000) Butterfly community structure in fragmented habitats. Ecology Letters 3, 449-456.

Thomas, C.D., Hanski, I. (1997) Butterfly metapopulations. Metapopulation biology: ecology, genetics, and evolution (eds Hanski I., Gilpin M.E.), pp. 359-386. Academic Press, San Diego, USA.

Thomas, C.D., Thomas, J.A., Warren, M.S. (1992) Distribution of occupied and vacant butterfly habitats in fragmented landscapes. Oecologia 92, 563-567.

Thomas, J.A., Bourn, N.A.D., Clarke, R.T., Stewart, K.E., Simcox, D.J., Pearman, G.S., Curtis, R., Goodger, B. (2001) The quality and isolation of habitat patches both determine where 
butterflies persist in fragmented landscapes. Proceedings of the Royal Society of London Biological Sciences 268, 1791-1796.

Thornton, I.W.B., Zahn, R.A., Stephenson, D.G. (1990) Colonization of the Krakatau Island by land birds, and the approach to an equilibrium number of species. Philosophical Transactions of the Royal Society of London Biological Sciences 327, 55-93.

Toft, C.A., Schoener, T.W. (1983) Abundance and diversity of orb spiders on 106 Bahamian islands: biogeography at an intermediate trophic level. Oikos 41, 411-426.

Tscharntke, T., Steffan-Dewenter, I., Kruess, A., Thies, C. (2002) The contribution of small habitat fragments to the conservation of insect communities of grassland-cropland landscape mosaics. Ecological Applications 12, 354-363.

Vandermeer, J., Carvajal, R. (2001) Metapopulation dynamics and quality of the matrix. The American Naturalist 158, 211-220.

Van Swaay, C.A.M. (2002) The importance of calcareous grasslands for butterflies in Europe. Biological Conservation 104, 315-318.

WallisDeVries, M.F., Poschlod, P., Willems, J.H. (2002) Challenges for the conservation of calcareous grasslands in northwestern Europe: integrating the requirements of flora and fauna. Biological Conservation 104, 265-273.

Warren, M.S., Hill, J.K., Thomas, J.A., Asher, J., Fox, R., Huntley, B., Roy, D.B., Telfer, M.G., Jeffcoate, S., Harding, P., Jeffcoate, G., Willis, S.G., Greatorex-Davis, J.N., Moss, D., Thomas C.D. (2001) Rapid responses of British butterflies to opposing forces of climate and habitat change. Nature 414, 65-69.

Whittaker, R.J. (1998) Island biogeography. Ecology, Evolution, and Conservation. Oxford University Press, Oxford, UK.

Wiens, J.A. (1997) Metapopulation dynamics and landscape ecology. Metapopulation biology: ecology, genetics, and evolution (eds Hanski I., Gilpin M.E.), pp. 43-62. Academic Press, San Diego, USA.

Wilcox, B.A., Murphy, D.D., Ehrlich, P.R., Austin, G.T. (1986) Insular biogeography of the montane butterfly faunas in the Great Basin: comparison with birds and mammals. Oecologia 69, 188194.

Zabel, J., Tscharntke, T. (1998). Does fragmentation of Urtica habitats affect phytophagous and predatory insects differentially? Oecologia 116, 419-425.

Zub, P. (1996) Die Widderchen Hessens. Mitteilungen des Internationalen Entomologischen Vereins, Supplementband IV, 1-122.

\section{APPENDIX}


Appendix 1 Habitat area, isolation, species and individual numbers of all studied 31 calcareous grasslands of 1996 and 2000.

\begin{tabular}{|c|c|c|c|c|c|c|c|c|c|c|c|}
\hline Study site & $\begin{array}{c}\text { Habitat } \\
\text { area } \\
\text { in } \mathrm{m}^{2}\end{array}$ & $\begin{array}{c}\text { Isolation } \\
\text { distance in } \\
\mathrm{m}\end{array}$ & $\begin{array}{l}\text { Isolation-in } \\
\text { dex }\end{array}$ & $\begin{array}{c}\text { Species } \\
1996\end{array}$ & $\begin{array}{c}\text { Specialist } \\
\text { species } \\
1996\end{array}$ & $\begin{array}{c}\text { Generalist } \\
\text { species } \\
1996\end{array}$ & $\begin{array}{c}\text { Total } \\
\text { number of } \\
\text { individuals } \\
1996 \\
\end{array}$ & $\begin{array}{c}\text { Species } \\
2000\end{array}$ & $\begin{array}{c}\text { Specialist } \\
\text { species } \\
2000\end{array}$ & $\begin{array}{c}\text { Generalist } \\
\text { species } \\
2000\end{array}$ & $\begin{array}{c}\text { Total } \\
\text { number of } \\
\text { individuals } \\
2000 \\
\end{array}$ \\
\hline 1 & 51,395 & 61 & 43,895 & 31 & 8 & 23 & 854 & 34 & 9 & 25 & 880 \\
\hline 2 & 38,776 & 55 & 85,978 & 32 & 9 & 23 & 1,114 & 38 & 12 & 26 & 866 \\
\hline 3 & 35,856 & 337 & 13,505 & 32 & 12 & 20 & 477 & 40 & 11 & 29 & 667 \\
\hline 4 & 29,400 & 1,143 & 25,911 & 26 & 9 & 17 & 1,492 & 29 & 9 & 20 & 1,308 \\
\hline 5 & 19,440 & 663 & 18,430 & 36 & 13 & 23 & 1,219 & 39 & 14 & 25 & 642 \\
\hline 6 & 16,000 & 1,300 & 5,017 & 36 & 10 & 26 & 1,277 & 42 & 15 & 27 & 1,440 \\
\hline 7 & 12,600 & 774 & 14,259 & 30 & 10 & 20 & 731 & 28 & 9 & 19 & 593 \\
\hline 8 & 11,528 & 394 & 16,704 & 34 & 13 & 21 & 919 & 40 & 13 & 27 & 1,012 \\
\hline 9 & 7,887 & 543 & 4,973 & 34 & 9 & 25 & 622 & 28 & 7 & 21 & 649 \\
\hline 10 & 7,420 & 1,274 & 14,643 & 35 & 10 & 25 & 596 & 34 & 10 & 24 & 354 \\
\hline 11 & 6,862 & 214 & 16,587 & 31 & 10 & 21 & 536 & 25 & 4 & 21 & 371 \\
\hline 12 & 6,338 & 122 & 27,966 & 29 & 8 & 21 & 570 & 30 & 11 & 19 & 431 \\
\hline 13 & 4,964 & 80 & 11,137 & 28 & 8 & 20 & 502 & 31 & 10 & 21 & 559 \\
\hline 14 & 4,526 & 122 & 17,346 & 27 & 6 & 21 & 352 & 24 & 6 & 18 & 826 \\
\hline 15 & 3,843 & 488 & 9,545 & 29 & 10 & 19 & 750 & 29 & 8 & 21 & 467 \\
\hline 16 & 3,760 & 410 & 24,642 & 32 & 7 & 25 & 414 & 29 & 6 & 23 & 351 \\
\hline 17 & 3,207 & 487 & 28,532 & 29 & 7 & 22 & 986 & 25 & 6 & 19 & 598 \\
\hline 18 & 2,444 & 170 & 18,383 & 34 & 11 & 23 & 393 & 32 & 10 & 22 & 765 \\
\hline 19 & 2,287 & 1,894 & 2,051 & 22 & 4 & 18 & 360 & 26 & 3 & 23 & 367 \\
\hline 20 & 1,914 & 130 & 6,804 & 24 & 2 & 22 & 116 & 25 & 3 & 22 & 303 \\
\hline 21 & 1,326 & 451 & 25,324 & 19 & 3 & 16 & 181 & 26 & 6 & 20 & 233 \\
\hline 22 & 1,133 & 775 & 6,005 & 28 & 5 & 23 & 387 & 17 & 1 & 16 & 111 \\
\hline 23 & 1,123 & 60 & 17,704 & 24 & 6 & 18 & 163 & 25 & 5 & 20 & 131 \\
\hline 24 & 920 & 550 & 40,713 & 27 & 7 & 20 & 284 & 27 & 4 & 23 & 218 \\
\hline 25 & 775 & 123 & 78,740 & 17 & 3 & 14 & 211 & 17 & 3 & 14 & 269 \\
\hline 26 & 661 & 576 & 31,985 & 22 & 4 & 18 & 205 & 24 & 3 & 21 & 144 \\
\hline 27 & 493 & 214 & 25,753 & 26 & 7 & 19 & 173 & 21 & 5 & 16 & 127 \\
\hline 28 & 489 & 710 & 14,612 & 20 & 2 & 18 & 181 & 21 & 2 & 19 & 204 \\
\hline 29 & 459 & 1,054 & 30,469 & 14 & 3 & 11 & 148 & 11 & 1 & 10 & 67 \\
\hline 30 & 329 & 1,428 & 15,488 & 20 & 4 & 16 & 159 & 20 & 0 & 20 & 81 \\
\hline 31 & 314 & 325 & 20,480 & 15 & 2 & 13 & 94 & 16 & 0 & 16 & 67 \\
\hline
\end{tabular}


Appendix 2 Butterfly and burnet species list from 1996 and 2000 on 31 calcareous grasslands. NoI: Number of individuals, NoH: Number of habitats (out of 31).

\begin{tabular}{|c|c|c|c|c|c|}
\hline Spring species (S) & Nol (total) & Nol (1996) & NoH (1996) & Nol (2000) & NoH (2000) \\
\hline \multicolumn{6}{|l|}{ Specialists: } \\
\hline & & & & & \\
\hline Polyommatus coridon (Poda, 1761) & 5,073 & 2,261 & 23 & 2,812 & 22 \\
\hline Zygaena carniolica (Scopoli, 1763) & 1,106 & 762 & 26 & 344 & 19 \\
\hline Coenonympha arcania (Linnaeus, 1761) & 472 & 127 & 17 & 345 & 16 \\
\hline Zygaena purpuralis (Brünnich, 1763) & 405 & 122 & 11 & 283 & 13 \\
\hline Zygaena viciae ([Denis \& Schiffermüller], 1775) & 394 & 227 & 22 & 167 & 14 \\
\hline Erynnis tages (Linnaeus, 1758) & 371 & 56 & 18 & 315 & 24 \\
\hline Thymelicus acteon (Rottemburg, 1775) & 280 & 147 & 26 & 133 & 18 \\
\hline Cupido minimus (Fuessly, 1775) & 272 & 23 & 8 & 249 & 8 \\
\hline Polyommatus agestis ([Denis \& Schiffermüller], 1775) & 212 & 97 & 19 & 115 & 17 \\
\hline Melitaea aurelia Nickerl, 1850 & 95 & 41 & 6 & 54 & 9 \\
\hline Colias alfacarensis Ribbe, 1905 & 69 & 46 & 7 & 23 & 5 \\
\hline Erebia medusa ([Denis \& Schiffermüller], 1775) & 69 & 27 & 4 & 42 & 5 \\
\hline Spialia sertorius (Hoffmannsegg, 1804) & 48 & 18 & 6 & 30 & 6 \\
\hline Hesperia comma (Linnaeus, 1758) & 44 & 14 & 4 & 30 & 4 \\
\hline Argynnis aglaja (Linnaeus, 1758) & 43 & 6 & 4 & 37 & 7 \\
\hline Zygaena lonicerae (Scheven, 1777) & 42 & 32 & 6 & 10 & 3 \\
\hline Boloria euphrosyne (Linnaeus, 1758) & 40 & 22 & 1 & 18 & 3 \\
\hline Zygaena hippocrepidis (Hübner, [1799]) & 22 & 1 & 1 & 21 & 4 \\
\hline Euphydryas aurinia (Rottemburg, 1775) & 20 & 19 & 1 & 1 & 1 \\
\hline Leptidea reali Reissinger, 1989 & 17 & 4 & 3 & 13 & 8 \\
\hline Argynnis adippe ([Denis \& Schiffermüller], 1775) & 5 & 5 & 3 & - & - \\
\hline Satyrium w-album (Knoch, 1782) & 3 & 3 & 3 & - & - \\
\hline Satyrium pruni (Linnaeus, 1758) & 1 & 1 & 1 & - & - \\
\hline Glaucopsyche arion (Linnaeus, 1758) & 1 & 1 & 1 & - & - \\
\hline Adscita sp. & 1 & 1 & 1 & - & - \\
\hline Sum & 9,105 & 4,063 & 222 & 5,042 & 206 \\
\hline \multicolumn{6}{|l|}{ Generalists: } \\
\hline Maniola jurtina (Linnaeus, 1758) & 6,180 & 2,713 & 31 & 3,467 & 30 \\
\hline Melanargia galathea (Linnaeus, 1758) & 2,976 & 2,615 & 31 & 361 & 28 \\
\hline Polyommatus icarus (Rottemburg, 1775) & 1,713 & 487 & 27 & 1,226 & 30 \\
\hline Aphantopus hyperantus (Linnaeus, 1758) & 1,516 & 1,229 & 31 & 287 & 30 \\
\hline Zygaena filipendulae (Linnaeus, 1758) & 1,385 & 1,007 & 30 & 378 & 27 \\
\hline Pieris rapae (Linnaeus, 1758) & 1,326 & 695 & 31 & 631 & 31 \\
\hline Coenonympha pamphilus (Linnaeus, 1758) & 1,299 & 405 & 27 & 894 & 31 \\
\hline Pieris napi (Linnaeus, 1758) & 1,186 & 765 & 31 & 421 & 31 \\
\hline Nymphalis io (Linnaeus, 1758) & 522 & 279 & 29 & 243 & 30 \\
\hline Vanessa cardui (Linnaeus, 1758) & 510 & 495 & 30 & 15 & 8 \\
\hline Nymphalis urticae (Linnaeus, 1758) & 462 & 227 & 27 & 235 & 27 \\
\hline Argynnis paphia (Linnaeus, 1758) & 461 & 258 & 28 & 203 & 22 \\
\hline Thymelicus sylvestris (Poda, 1761) & 458 & 403 & 29 & 55 & $\overline{17}$ \\
\hline Pyrgus malvae (Linnaeus, 1758) & 372 & 46 & 18 & 326 & 26 \\
\hline Callophrys rubi (Linnaeus, 1758) & 334 & 80 & 17 & 254 & 20 \\
\hline Ochlodes sylvanus (Esper, [1778]) & 325 & 186 & 27 & 139 & 27 \\
\hline Pieris brassicae (Linnaeus, 1758) & 250 & 86 & 24 & 164 & 27 \\
\hline Gonepteryx rhamni (Linnaeus, 1758) & 229 & 92 & 23 & 137 & 27 \\
\hline Araschnia levana (Linnaeus, 1758) & 194 & 62 & 24 & 132 & 29 \\
\hline Carterocephalus palaemon (Pallas, 1771) & 130 & 40 & 18 & 90 & 22 \\
\hline Issoria lathonia (Linnaeus, 1758) & 123 & 118 & 22 & 5 & 3 \\
\hline Anthocharis cardamines (Linnaeus, 1758) & 113 & 9 & 8 & 104 & 25 \\
\hline Pararge aegeria (Linnaeus, 1758) & 102 & 10 & 5 & 92 & 26 \\
\hline Hamearis lucina (Linnaeus, 1758) & 75 & 13 & 7 & 62 & 17 \\
\hline Plebeius argus (Linnaeus, 1758) & 53 & 13 & 2 & 40 & 5 \\
\hline Lycaena phlaeas (Linnaeus, 1761) & 39 & 20 & 12 & 19 & 7 \\
\hline Thymelicus lineola (Ochsenheimer, 1808) & 35 & 17 & 8 & 18 & 6 \\
\hline Lasiommata megera (Linnaeus, 1767) & 23 & 8 & 6 & 15 & 7 \\
\hline Papilio machaon Linnaeus, 1758 & 14 & 2 & 2 & 12 & 8 \\
\hline Nymphalis c-album (Linnaeus, 1758) & 13 & 2 & 2 & 11 & 8 \\
\hline Celastrina argiolus (Linnaeus, 1758) & 13 & - & - & 13 & 8 \\
\hline Vanessa atalanta (Linnaeus, 1758) & 10 & 10 & 8 & - & - \\
\hline Limenitis camilla (Linnaeus, 1764) & 7 & 3 & 2 & 4 & 3 \\
\hline Erebia aethiops (Esper, [1777]) & 6 & 6 & 2 & - & - \\
\hline Thecla betulae (Linnaeus, 1758) & 5 & 1 & 1 & 4 & 2 \\
\hline Lycaena tityrus (Poda, 1761) & 3 & 1 & 1 & 2 & 2 \\
\hline Sum & 22,462 & 12,403 & 621 & 10,059 & 647 \\
\hline
\end{tabular}




\title{
How does landscape context contribute to effects of habitat fragmentation on diversity and population density of butterflies?
}

\begin{abstract}
Studies on habitat fragmentation of insect communities mostly ignore the impact of the surrounding landscape matrix and treat all species equally. In our study on habitat fragmentation and the importance of landscape context, we expected that habitat specialists are more affected by area and isolation, and habitat generalists more by landscape context.
\end{abstract}

The study was conducted in the vicinity of the city of Göttingen in Germany in the year 2000. We analyzed butterfly communities by transect counts on 32 calcareous grasslands differing in size (0.03 - 5.14 ha), isolation index $(2,100$ - 86,000 / edge-to-edge distance 55 1,894 m), and landscape diversity (Shannon Wiener: 0.09 - 1.56), which is correlated with percent grassland in the landscape.

A total of 15,185 butterfly specimens belonging to 54 species are recorded. In multiple regression analysis, the number of habitat specialist $(n=20)$ and habitat generalist $(n=34)$ butterfly species increased with habitat area, but $z$-values (slopes) of the species-area relations for specialists $(z=0.399)$ were significantly steeper than for generalists $(z=0.096)$. Generalists, but not specialists, increased marginally significantly with landscape diversity. Effects of landscape diversity were scale-dependent and significant only at the smallest scale (landscape context within a $250 \mathrm{~m}$ radius around the habitat). Habitat isolation was not related to specialist and generalist species numbers. In multiple regression analysis the density of specialists increased significantly with habitat area, whereas generalist density increased only marginally. Habitat isolation and landscape diversity did not show any effects.

Habitat area was the most important predictor of butterfly community structure and influenced habitat specialists more than habitat generalists. In contrast to expectations, habitat isolation had no effect as the most butterflies could cope with the degree of isolation in our study region. Landscape diversity appeared to be important for generalist butterflies only.

KEYWORDS habitat area, habitat isolation, habitat quality, specialists, generalists, conservation, burnets, species-area relationships 


\section{INTRODUCTION}

Most species live in habitat islands of fragmented landscapes (Wiens 1997, Hanski 1999). Habitat area (Connor et al. 2000, Zschokke et al. 2000), habitat isolation (Hanski et al. 1994, Kruess \& Tscharntke 1994, Steffan-Dewenter \& Tscharntke 1999, Ricketts et al. 2001, Thomas et al. 2001), and habitat quality including effects of management and age (Feber et al. 1996, Gonzalez 2000, Swengel \& Swengel 2001, Thomas et al. 2001) are known to affect species richness and population densities. Unlike oceanic islands, where the marine environment is a clear isolation barrier, the matrix of the surrounding landscape may contribute to the survival of populations in terrestrial habitat islands (Marino \& Landis 1996, Jonsen \& Fahrig 1997, Thies \& Tscharntke 1999, Weibull et al. 2000, Steffan-Dewenter et al. 2002).

Species-area relationships have been shown for many taxonomic groups (Rosenzweig 1995), including butterflies (Wilcox et al. 1986, Baz \& Garcia-Boyero 1995, Robertson et al. 1995, Wettstein \& Schmid 1999, Steffan-Dewenter \& Tscharntke 2000, Zschokke et al. 2000). However, comparative studies on species groups differing in ecological traits are rare (Harrison \& Bruna 1999). Population density studies for insects are also not common, and show that densities can decrease or increase with increasing habitat area (Connor et al. 2000, Matter 2000, Steffan-Dewenter \& Tscharntke 2000).

Most studies on fragmentation of terrestrial habitats ignore the potential influence of the surrounding landscape on species richness and population density, and focus on area and isolation only (Wiens 1997, Hanski 1999, Vandermeer \& Carvajal 2001, Tscharntke et al. 2002). However, many grassland butterflies exist as metapopulations in fragmented habitats and may profit from adjacent vegetation depending on the matrices of the surrounding landscapes (Thomas \& Hanski 1997). Habitat specialists have been predicted to be particularly affected by habitat fragmentation (Thomas et al. 1992, Warren et al. 2001), whereas generalists should be more strongly affected by the surrounding landscape diversity (Jonsen \& Fahrig 1997). Landscape analyses have found negative effects for species richness with increasing habitat isolation (Wettstein \& Schmid 1999, Ricketts et al. 2001) and variable effects with landscape context as different species may respond at different spatial scales (e.g. Jonsen \& Fahrig 1997, Weibull et al. 2000, Steffan-Dewenter et al. 2001, 2002).

In the temperate zone, butterfly species richness is known to be high on grasslands (Oates 1995, Pfaff \& Wolters 1999). Calcareous grasslands rank as the most species-rich habitat for butterflies in Europe (Van Swaay 2002). In this study we tested whether habitat area, habitat isolation, habitat quality or landscape context affect species richness and 
population density of specialist and generalist butterflies and burnets on calcareous grasslands. The following predictions were tested:

(1) Species richness increases with increasing habitat area, decreasing habitat isolation, and increasing habitat quality.

(2) Species richness increases with increasing habitat diversity of the surrounding landscape.

(3) Total butterfly and burnet densities and densities of single species depend on habitat area, habitat isolation, habitat quality, and are affected by landscape context.

(4) Habitat specialists are more sensitive to habitat area and isolation, whereas generalists are more sensitive to landscape context.

\section{MATERIALS AND METHODS}

\section{Study region and study sites}

A total of 32 calcareous grasslands in the vicinity of the city of Göttingen in Lower Saxony (Germany) were studied (Fig. 1). The study sites were chosen to cover the full gradient of habitat area and isolation in the study region. Calcareous grasslands cover only $0.26 \%$ of the area in the study region and are sharply delimited from the surrounding landscape matrix. The natural fragmentation of the semi-natural calcareous grasslands increased extremely, due to intensification of agricultural development during the last decades in Germany (WallisdeVries et al. 2002). In Lower Saxony the total area of calcareous grasslands is much lower and probably more fragmented than in Southern Germany (WallisdeVries et al. 2002). Compared to Northern Europe our study region might be still less fragmented. The study sites were neither grazed nor mown during the sampling period in the year 2000 and belong to the plant association Gentiano-Koelerietum. Our study region includes a total of 285 calcareous grasslands with an area of $5.01 \mathrm{~km}^{2}$ (unpublished data following official maps from the "Niedersächsisches Landesamt für Ökologie", "Untere Naturschutzbehörden Stadt und Landkreis Göttingen, Landkreis Northeim und Landkreis Heiligenstadt", "Regierungspräsidium Kassel").

\section{Butterflies}

Butterflies (Lepidoptera: Hesperioidea and Papilionoidea) and burnets (Lepidoptera: Zygaenidae) were sampled in 2000 (26 April - 24 August) by visual counts along five randomized transect walks through each of the 32 study sites. In the following, butterflies always include burnets. The number of species and individuals were recorded within a $5 \mathrm{~m}$ corridor when weather conditions were suitable for butterfly activity (see Pollard 1977, 
Erhardt 1985). All study sites were sampled in a randomized sequence every 3 - 4 weeks within the total sampling time. During each of the five sampling periods all 32 study sites were sampled within six to eleven days, to minimize phenology effects. To achieve adequate sample sizes, transect time varied from 20 - 60 minutes, depending on the size of the grassland. Transect time for 12 small grasslands $\left(314-1,326 \mathrm{~m}^{2}\right)$ was 20 minutes per transect walk, for 12 intermediate grasslands $\left(1,914-7,887 \mathrm{~m}^{2}\right) 40$ minutes, and for 8 large grasslands $\left(11,528-51,395 \mathrm{~m}^{2}\right) 60$ minutes. Counts were conducted in 5 minute intervals to calculate species accumulation curves (following Colwell 1997, see below). Transect distance was measured during each transect walk with an electronic step counter allowing calculations of butterfly densities per 100 square meters for all 32 study sites. Species numbers and population densities from the five transect walks were pooled for each study site over the sampling period.

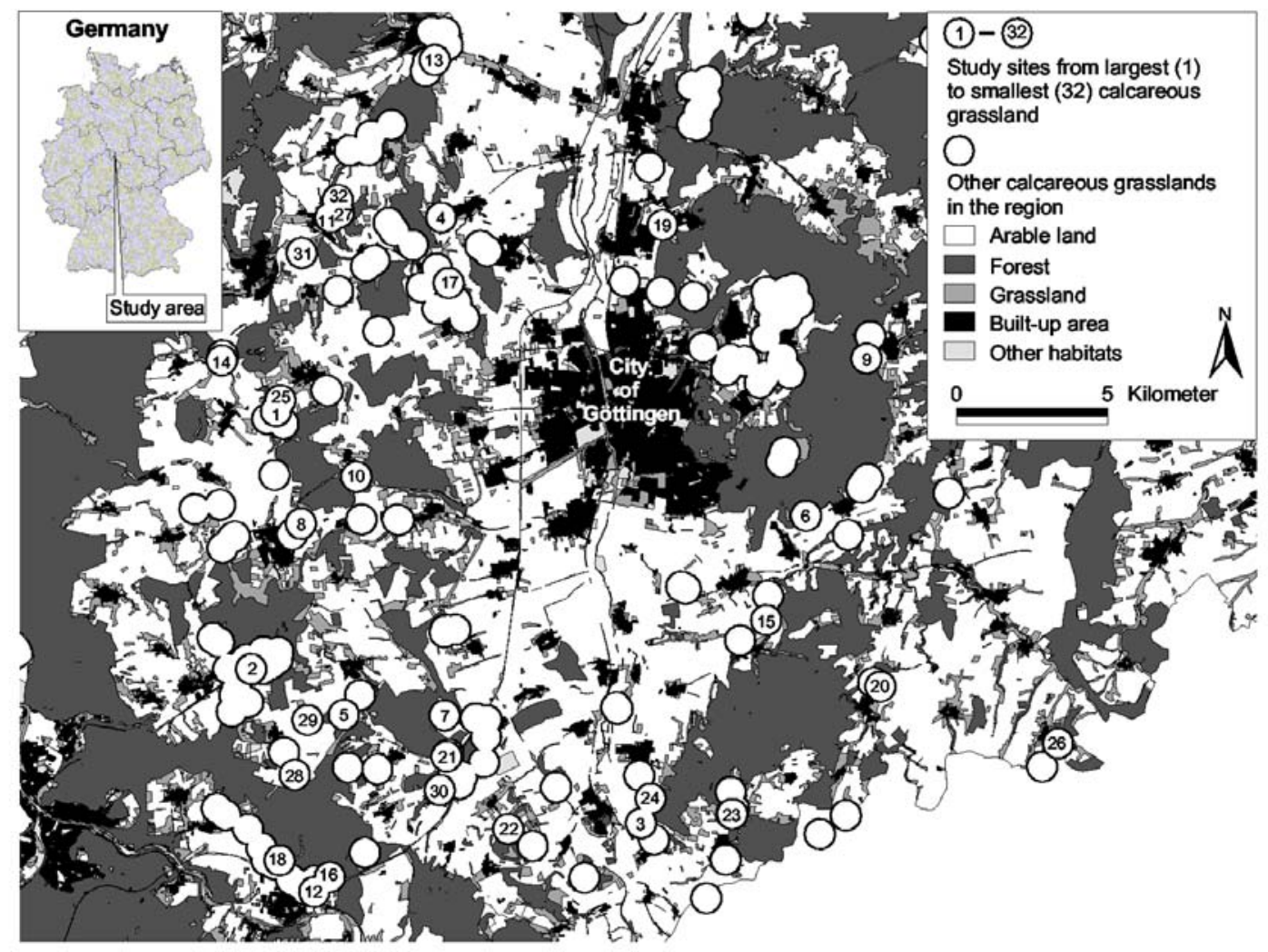

Figure 1 Location of the 32 calcareous grasslands studied, and all further calcareous grasslands around the city of Göttingen (the city is in the centre of the map). Each grassland is marked by a circle (with $500 \mathrm{~m}$ radius), and the study sites are numerated from the largest (1) to the smallest (32).

We defined butterfly species as habitat specialists $(n=20)$ for calcareous grassland when they are found in Lower Saxony almost exclusively on calcareous grasslands (based on unpublished data from the known distribution of butterflies of Lower Saxony, personal 
communication Hans Joger "Niedersächsisches Landesamt für Ökologie", Hildesheim). Most of these species were also recorded in Zub (1996) and Settele et al. (1999) as calcareous grassland specialists or with strong preferences for this habitat type. However, some of these specialists can inhabit additional habitats in other regions of Germany or Europe, but are restricted in Lower Saxony to calcareous grasslands, because of larval food plant limitation or climatic tolerances. We defined butterflies as habitat generalists $(n=34)$ when they are ubiquitous species or species with preferences for other habitat types, following Zub (1996) and Settele et al. (1999). Similarly Warren et al. (2001) classified British butterflies in two groups as wider-countryside or habitat specialist species.

\section{Habitat area, isolation, quality, and the landscape context}

\section{Habitat area}

The area of the 32 calcareous grasslands was measured in the year 2000 with a differential GPS GEOmeter 12L (GEOsat GmbH 1998) and ranged from $314-51,395 \mathrm{~m}^{2}$. The area of former grassland, which was completely covered by shrubs, was excluded in this measurement.

\section{Habitat isolation}

To calculate the isolation of grasslands we checked the 285 officially mapped calcareous grasslands in the region. Of these 222 of them were still grasslands, whereas 63 were covered by shrubs and trees due to lack of management, and were excluded for isolation calculations in this study. Estimation of habitat area from the official maps with exclusion of the area covered by shrubs was closely correlated to our GPS measurements $(n=32, r=0.936, p<$ $0.0001)$ for the 32 study sites. Habitat isolation $(I)$ of each study site $(i)$ was measured from edge-to-edge and took all known calcareous grasslands in a radius of $8 \mathrm{~km}$ around our study sites into account, using the following formula:

$I=\Sigma \exp \left(-a * d_{i j}\right) * A_{j}^{b}$

where $A_{j}$ is the size (in $\mathrm{m}^{2}$ ) of neighboring calcareous grasslands and $d_{i j}$ the distance (in $\mathrm{km}$ ) from the neighboring grassland $j$ to the study site $i$. The parameter $a$ determines the effect of distance on isolation, the parameter $b$ the scaling of immigration. The formula is based on Hanski et al. (2000), and was used in a simpler form with $a=1$ and $b=1$ by Hanski et al. (1994) and Steffan-Dewenter and Tscharntke (2000). Larger values of the isolation index I indicate lower isolation (and better connectivity) than smaller values. We tested $d_{i j}$ multiplied 
with the factors $a=1$ and $a=3$, and $A_{j}$ with the exponents of $b=1, b=0.2$ and $b=0.5$ (plus all combinations) to take into account the possibility of different dispersal distances and immigration rates of butterflies (see Moilanen \& Nieminen 2002). The resulting habitat isolation indices were similar to each other, and closely correlated $(r>0.6)$. We also tested the distance to the nearest calcareous grassland, following Thomas et al. (1992, 2001). Isolation index $(a=1, b=1)$ and distance were correlated $(r=-0.44, p=0.012)$ and gave very similar results with respect to the butterfly communities. $\log _{10}$-transformed indices and distances were tested for specialist, generalist and total butterfly species richness and density and gave always non-significant results. Therefore we only show results of the isolation index with $a=1$ and $b=1$.

\section{Landscape context}

Landscape context was analysed using modified digital thematic maps (ATKIS ${ }^{2}$-DLM 25/1 Landesvermessung \& Geobasisinformationen Niedersachsen 1991 - 1996, and ATKIS®DLM 25/2 Hessisches Landesvermessungsamt 1996). In total, the study region covers an area of about $1,944 \mathrm{~km}^{2}$. We pooled the mainly semi-natural land-use types, grassland $(12.14 \%)$, garden land $(0.31 \%)$, hedgerows $(0.30 \%)$, calcareous grasslands $(0.26 \%)$, orchard meadows $(0.20 \%)$ and fen $(0.05 \%)$, and defined them as "grasslands" (13.26\%), because these habitats were assumed to be the most suitable nectar habitats for adult butterflies. The remaining landuse types contain arable land (42.15\%), forest (36.80\%), built-up area (6.24\%), other habitats $(1.48 \%)$ and plantations $(0.06 \%)$ (see Steffan-Dewenter et al. 2001, 2002). The proportion of the defined grassland habitats showed no significant relationships and was correlated with landscape diversity (see results).

We used the Shannon-Wiener index to calculate landscape diversity following Thies and Tscharntke (1999) and Steffan-Dewenter et al. (2002) as:

$H s=-\Sigma p_{i} * \ln p_{i}$

where $p_{i}$ is the proportion of each of the mentioned eleven land use types (Krebs 1989). Landscape context was quantified for each of the 32 grassland fragments using a nested set of circles around the center of the study sites from $0.25 \mathrm{~km}$ to $3.00 \mathrm{~km}$ in $0.25 \mathrm{~km}$ steps. Due to a few missing ATKIS values we could test the landscape context for a radius of 0.25 and 0.50 $\mathrm{km}$ for all 32 study sites, whereas $0.75-2.00 \mathrm{~km}$ scales were tested for only $31,2.25 \mathrm{~km}$ for 30 , and $2.50-3.00 \mathrm{~km}$ for 29 sites. For each landscape analysis, habitat area of the study site was excluded to reduce the habitat area effect. 


\section{Habitat quality}

Habitat quality was quantified after each transect walk (i) by estimating the proportion of area covered by blooming plants within the transect area to quantify nectar resources and (ii) by identifying all blooming plant species inside the transect area as indicator of larval food plant availability. The number of blooming plant species per study site was highly correlated to the number of all vascular plant species per study site $(n=31, r=0.922, p<0.0001)$ (unpublished data, J. Krauss).

\section{Statistical analyses}

The statistical analyses were performed using the software "Statgraphics Plus for Windows 3.0" (Statgraphics 1995). All data were tested if they satisfy the assumption of normality. We calculated simple and multiple regressions, Pearson and Spearman rank correlations, multiple logistic regressions and comparison of regression lines (Sokal \& Rohlf 1995). We chose stepwise backward elimination for multiple regressions. The independent variables habitat area and isolation were always $\log _{10}$ transformed, cover of blooming plant species was arcsine-square root transformed, whereas the proportion of grassland habitats in the surrounding landscape was normally distributed. Species numbers in regressions were also $\log _{10}$ transformed to calculate slopes of $z$-values to compare them with other studies. Arithmetic means of not transformed values \pm one standard error are given in the text.

We calculated the species richness estimator ACE (Abundance-based Coverage Estimator of species richness, computed by EstimateS, Version 5, Colwell 1997) to indicate the percentage of sampled in relation to estimated species richness per habitat, showing the saturation of species richness. To avoid effects of season dependent species turnover we pooled the first 5 minutes of all five transect walks per habitat to a first 25 minute interval (first step), the next 5 minutes of the transects were pooled to a second 25 minute interval (second step) and so on. Small habitats with $20 \mathrm{~min}$ transect walks have therefore 4 steps, intermediate habitats 8 steps and large habitats 12 steps to calculate the estimated species richness.

\section{RESULTS}

In total we recorded 48 butterfly species and six species of burnets, comprising a total of 15,185 individuals on all 32 calcareous grasslands. Only Pieris rapae (L.) and P. napi (L.) could be found on all calcareous grassland fragments (Appendix). The most abundant species 
were the satyrid Maniola jurtina (L.) (22.9 \% of all individuals), and the lycaenids Polyommatus coridon (Poda) (18.5 \%) and Polyommatus icarus (Rottemburg) (8.1\%).

The comparison of sampled with estimated species, which were calculated with the species richness estimator ACE, showed that $90.24 \pm 1.18 \%$ (minimum $74.73 \%$, maximum $98.91 \%$ ) of the species were found in each study site. No correlation between this proportion and the independent factors habitat area (Spearman rank correlation $n=32: r=0.212, p=$ $0.237)$, isolation $(r=0.023, p=0.899)$, number $(r=0.168, p=0.351)$ and cover $(r=0.129, p$ $=0.471)$ of blooming plant species, landscape diversity $(r=0.076, p=0.671)$, and the percentage of grasslands in the surrounding landscape $(r=0.132, p=0.463)$ were found. Smoothed sample size - butterfly species number accumulation curves asymptote (unpublished data, J. Krauss). These results justify the usage of sampled species numbers instead of estimated species numbers.

Table 1 Pearson correlation coefficients $(r)$ are shown for the relations between the independent variables of the 32 calcareous grasslands. Habitat area and habitat isolation are $\log _{10}$ transformed, cover of blooming plant species is arcsine-square root transformed. Significance levels are: $* * * p<0.001, * * p<0.01, * p<0.05,(*) p<$ 0.1, n.s. $=$ not significant.

\begin{tabular}{|c|c|c|c|c|c|}
\hline & $\begin{array}{l}\text { Habitat } \\
\text { isolation }\end{array}$ & $\begin{array}{l}\text { Landscape } \\
\text { diversity } \\
\text { (Radius: } \\
\text { 250m) }\end{array}$ & $\begin{array}{l}\text { Grassland } \\
\text { habitats } \\
\text { (Radius: } \\
\text { 250m) }\end{array}$ & $\begin{array}{l}\text { Number of } \\
\text { blooming } \\
\text { plant species }\end{array}$ & $\begin{array}{l}\text { Cover of } \\
\text { blooming plant } \\
\text { species }\end{array}$ \\
\hline Habitat area & -0.2 n.s. & $0.32(*)$ & $0.40 *$ & $0.69 * * *$ & $0.46 * *$ \\
\hline Habitat isolation & - & -0.01 n.s. & 0.15 n.s. & $-0.30(*)$ & -0.28 n.s. \\
\hline $\begin{array}{l}\text { Landscape diversity } \\
\text { (Radius: } 250 \mathrm{~m} \text { ) }\end{array}$ & - & - & $0.64 * * *$ & 0.17 n.s. & 0.09 n.s. \\
\hline $\begin{array}{l}\text { Grassland habitats } \\
\text { (Radius: } 250 \mathrm{~m} \text { ) }\end{array}$ & - & - & - & 0.20 n.s. & 0.01 n.s. \\
\hline $\begin{array}{l}\text { Number of blooming } \\
\text { plant species }\end{array}$ & - & - & - & - & $0.39 *$ \\
\hline
\end{tabular}

Habitat area (0.03 - 5.14 ha) was not correlated with habitat isolation (index: 2,100 - 86,000), and only marginally with landscape diversity (at a $250 \mathrm{~m}$ scale; Shannon Wiener: 0.09 - 1.56) (Table 1). Distance to the nearest calcareous grassland differed from 55 to $1,894 \mathrm{~m}$. The proportion of grassland habitats $(0.42-58.37 \%)$ was correlated to landscape diversity and the 
two characteristics of habitat quality, the number (average: 11.2 - 24.8 species) and cover $(2.10-14.09 \%)$ of blooming plant species were highly correlated with habitat area (Table 1). For further analysis we excluded (i) the proportion of grassland habitats and (ii) the two habitat quality characteristics.

\section{Species richness of butterflies}

The species-area relationship for all butterflies was highly significant. Species richness of both the specialists and generalists increased significantly with increasing habitat area (Fig. 2, Table 2).

Table 2 Simple regressions between the number of species and the density of all butterflies (54 species), specialists (20 species) and generalists (34 species) and the three independent factors habitat area, habitat isolation, and landscape diversity of the 32 calcareous grasslands. Habitat area and habitat isolation are $\log _{10}$ transformed.

\begin{tabular}{l|l|l|l|l|l|l|l|l|l}
$\begin{array}{l}\text { Species } \\
\text { numbers }\end{array}$ & \multicolumn{3}{l}{ Habitat area } & \multicolumn{3}{l}{ Habitat isolation } & \multicolumn{3}{l}{$\begin{array}{l}\text { Landscape diversity } \\
\text { (Radius: 250m) }\end{array}$} \\
\hline & $F$ & $r$ & $p$ & $F$ & $r$ & $p$ & $F$ & $r$ & $p$ \\
all species & 69.96 & 0.836 & $<0.0001$ & 0.24 & -0.089 & 0.626 & 7.05 & 0.436 & 0.013 \\
specialists & 69.34 & 0.835 & $<0.0001$ & 0.01 & 0.020 & 0.939 & 4.23 & 0.352 & 0.049 \\
generalists & 29.36 & 0.703 & $<0.0001$ & 1.02 & -0.181 & 0.320 & 7.76 & 0.453 & 0.009
\end{tabular}

\begin{tabular}{l|l|l|l|l|l|l|l|l|l} 
Densities & \multicolumn{3}{l}{ Habitat area } & \multicolumn{3}{l}{ Habitat isolation } & \multicolumn{3}{l}{$\begin{array}{l}\text { Landscape diversity } \\
\text { (Radius: 250m) }\end{array}$} \\
\hline & $F$ & $r$ & $p$ & $F$ & $r$ & $p$ & $F$ & $r$ & $p$ \\
all species & 7.82 & 0.455 & 0.009 & 0.12 & -0.063 & 0.731 & 0.86 & 0.167 & 0.361 \\
specialists & 8.65 & 0.473 & 0.006 & 0.00 & -0.002 & 0.992 & 1.81 & 0.239 & 0.188 \\
generalists & 2.99 & 0.301 & 0.094 & 0.36 & -0.109 & 0.552 & 0.05 & 0.042 & 0.820
\end{tabular}

Comparison of these regressions showed no differences in slopes $(F=0.88, p=0.353)$. In contrast, the $z$-value (slope of $\log$-log regressions) for all butterfly species was $z=0.164$, and significantly higher for habitat specialists $(z=0.399)$ than for generalists $(z=0.096$; comparison of slopes: $F=31.53, p<0.0001)$. The presence of 14 specialist $(70 \%)$ and 10 generalist (29\%) butterfly species was determined by habitat area (Appendix). 


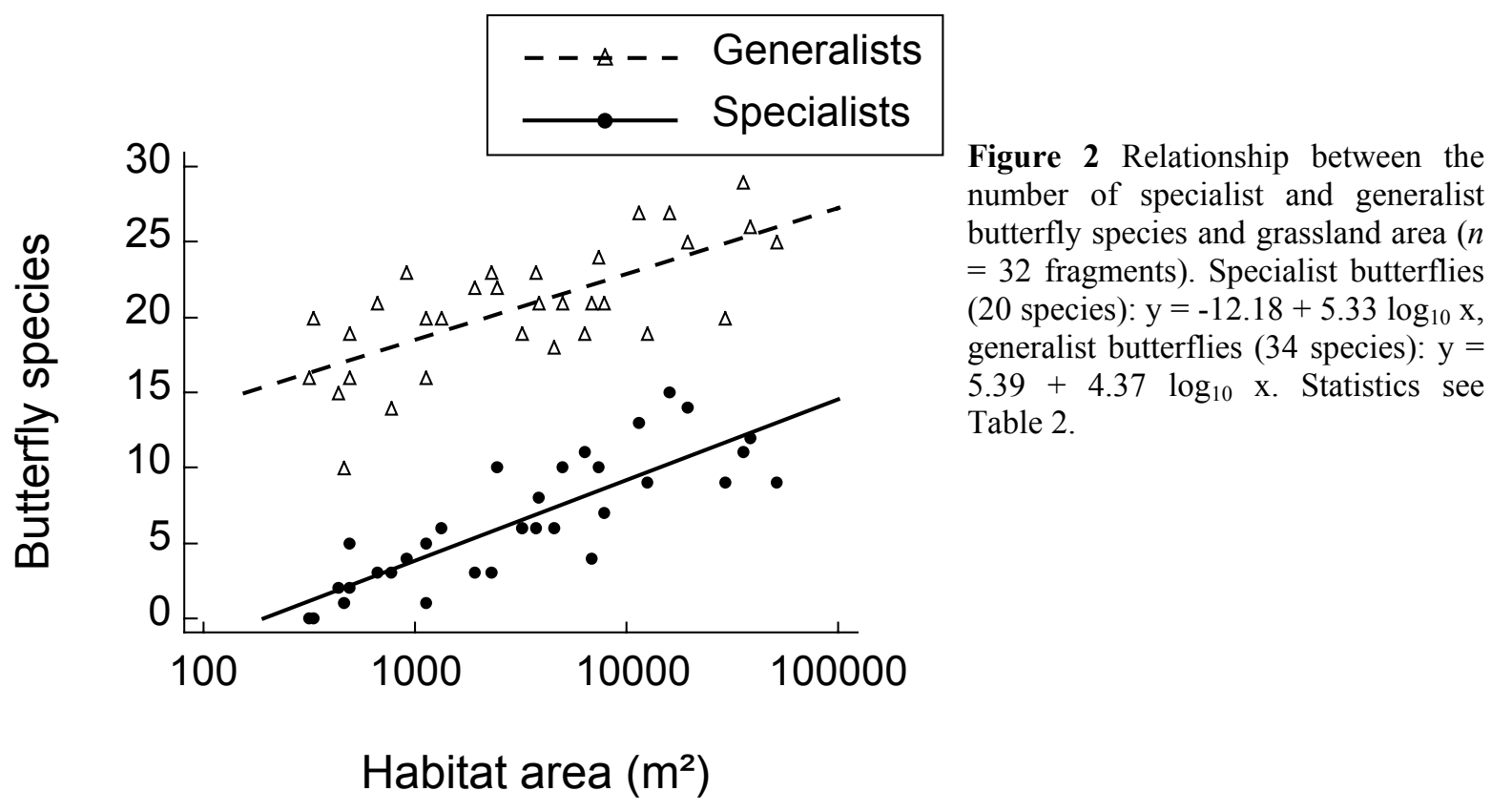

Neither number of species of all butterflies nor that of only the specialists or generalists showed a significant relation to the habitat isolation index (Fig. 3, Table 2). Also all other isolation calculations did not show any significant effect of habitat isolation (results not shown). Only the presence of the two specialist species Polyommatus coridon and Zygaena carniolica (Scopoli) appeared to increase with increasing habitat connectivity (Appendix).

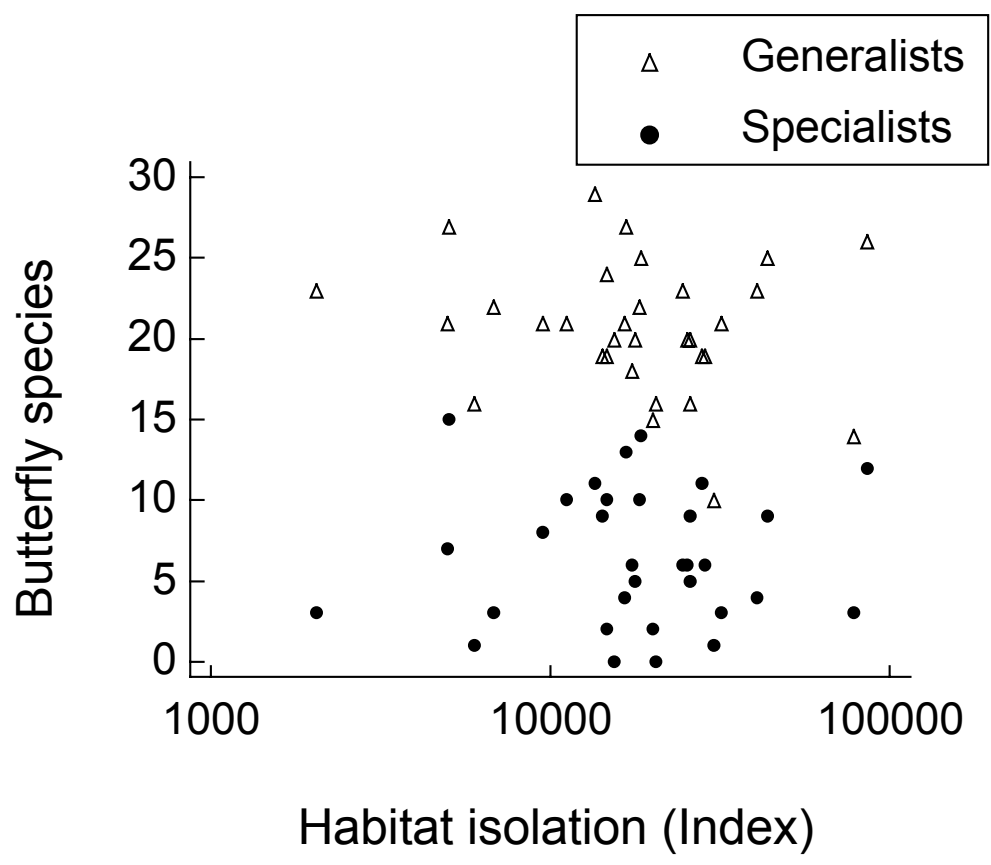

Figure 3 Relationship between the number of specialist and generalist butterfly species and habitat isolation ( $n=32$ fragments). Specialist butterflies (20 species), generalist butterflies (34 species). Statistics see Table 2. 
Species number of all butterflies, specialists, and generalists increased significantly with increasing diversity of the surrounding landscape, using a $250 \mathrm{~m}$ radius of the landscape sector for the calculation (Fig. 4, Table 2). Comparison of regressions between specialists and generalists showed no differences in slopes $(F=0.15, p=0.702)$. The presence of two specialist and five generalist butterfly species could be explained by increasing landscape diversity (Appendix).

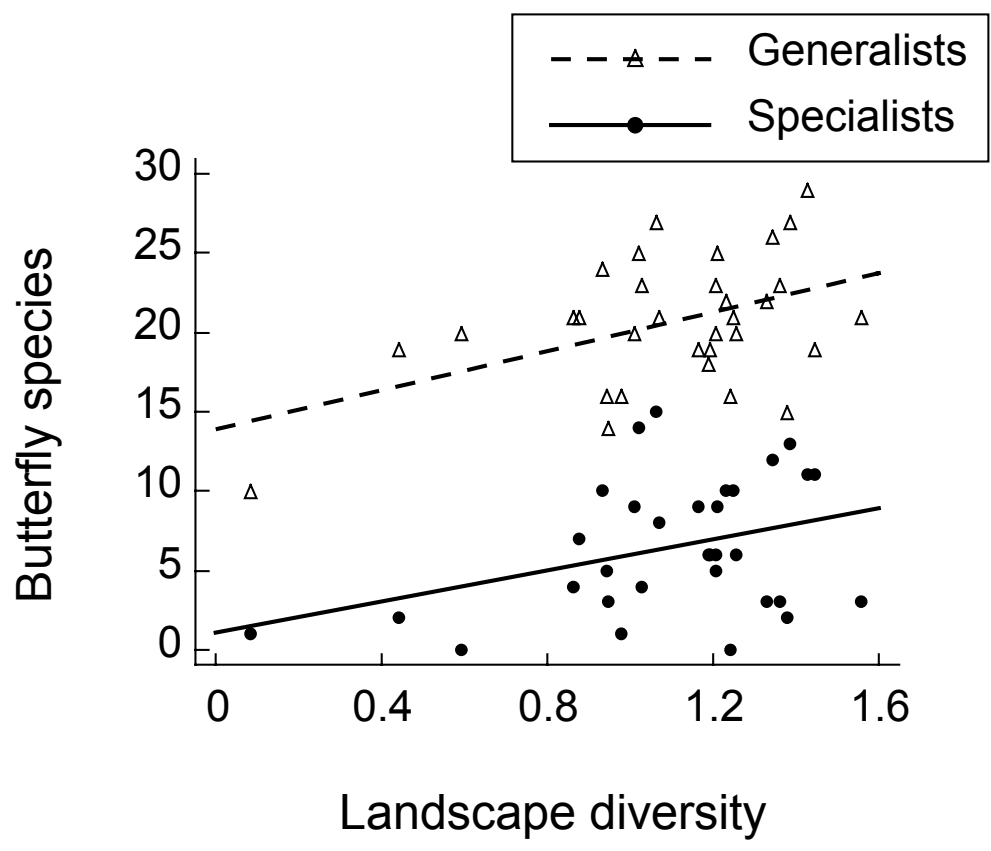

Figure 4 Relationship between the number of specialist and generalist butterfly species and landscape diversity, calculated as ShannonWiener Index at the $250 \mathrm{~m}$ landscape scale ( $n=32$ fragments). Specialist butterflies (20 species): y $=1.11+4.89 \mathrm{x}$, generalist butterflies ( 34 species): $\mathrm{y}=13.93+$ 6.14 x. Statistics see Table 2.

In multiple regression models, habitat area was the only explaining factor for the species number of all butterflies $(70.0 \%)$, the specialists $(69.8 \%)$, and generalists $(49.5 \%$; see the simple regressions, Table 2$)$. When we included also marginally significant factors $(p<0.1)$ in the multiple regression model, landscape diversity explained a further $3.1 \%$ for all butterfly species, and $5.8 \%$ for generalists. None of the isolation measurements had a negative effect for species richness in multiple regressions (results not shown).

We analyzed the effects of landscape context at 12 nested spatial scales. Landscape diversity and proportion of grassland habitats correlated best with the number of butterfly species at the smallest scale of $250 \mathrm{~m}$ for both the specialists and generalists (Fig. 5). Generalist butterflies showed higher correlations with landscape diversity than specialist butterflies (Fig. 5). In contrast, the proportion of grassland habitats showed no significant relationships, neither for specialists (250 m: $r=0.22, p=0.129)$ nor generalists $(250 \mathrm{~m}: r=$ $0.28, p=0.117)$. 


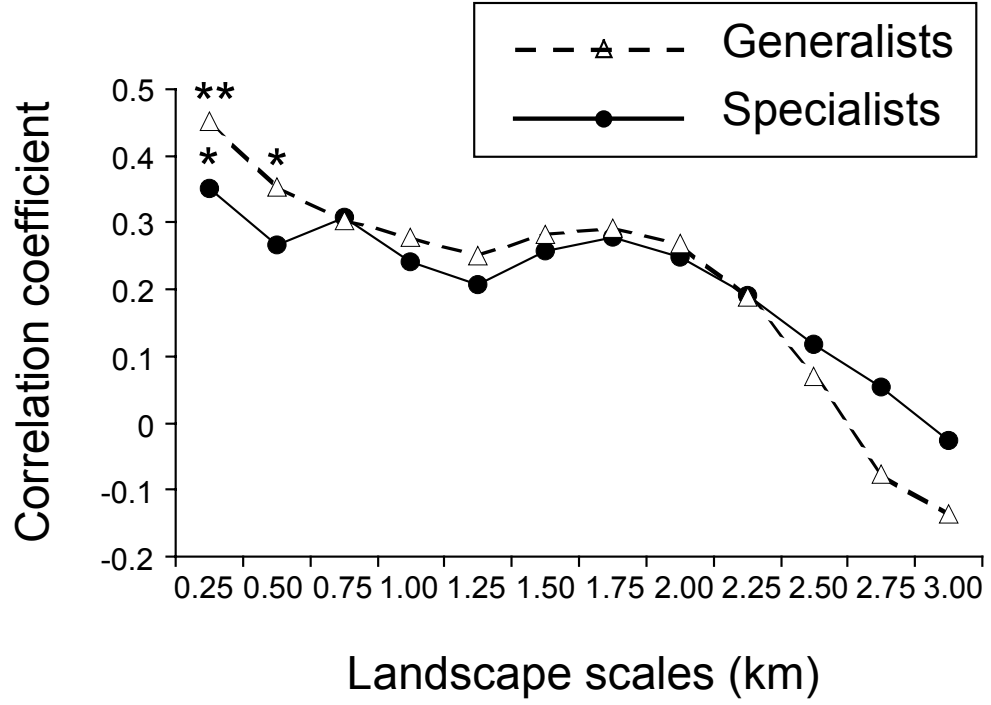

Figure 5 Pearson correlation coefficients between number of 20 specialist and 34 generalist butterfly species and landscape diversity (Shannon-Wiener-Index).

Landscape diversity is calculated for different spatial scales ranging from a radius of 0.25 to $3.00 \mathrm{~km}$. ** $p<0.01, * p<0.05$.

\section{Density of butterflies}

The density of all butterflies and of the specialists increased significantly with increasing habitat area, whereas generalist density increased only marginally significantly with habitat area (Fig. 6, Table 2). Eleven of 20 specialist species (55\%) showed significantly increasing population densities with increasing habitat area, while only seven out of 34 generalists (21 \%) showed this trend. Density of Pieris napi was significantly negatively correlated with increasing habitat area (Appendix). Butterfly densities on calcareous grasslands did not correlate with the habitat isolation index, neither for all butterflies, nor specialists or generalists (Table 2). Also all other isolation calculations showed no significant effects of habitat isolation (results not shown). Except for Plebeius argus (L.), which showed decreasing densities with decreasing isolation, none of the other 53 butterfly species showed any significant relation to habitat isolation (Appendix). No correlations between densities of all butterflies, specialists or generalists with landscape diversity were found (Table 2). Only the density of Spialia sertorius (Hoffmannsegg) increased significantly with increasing landscape diversity (Appendix).

In multiple regression models, habitat area was the only factor related to the density of all butterflies (explaining $20.7 \%$ of the variation) and specialists $(22.4 \%$ ), while generalists showed only a marginally significant relationship (9.1\%) (see simple regressions Table 2). Correlations with habitat isolation and landscape diversity were not even marginally significant. Also all other isolation calculations had no significant effects on species density (results not shown). 


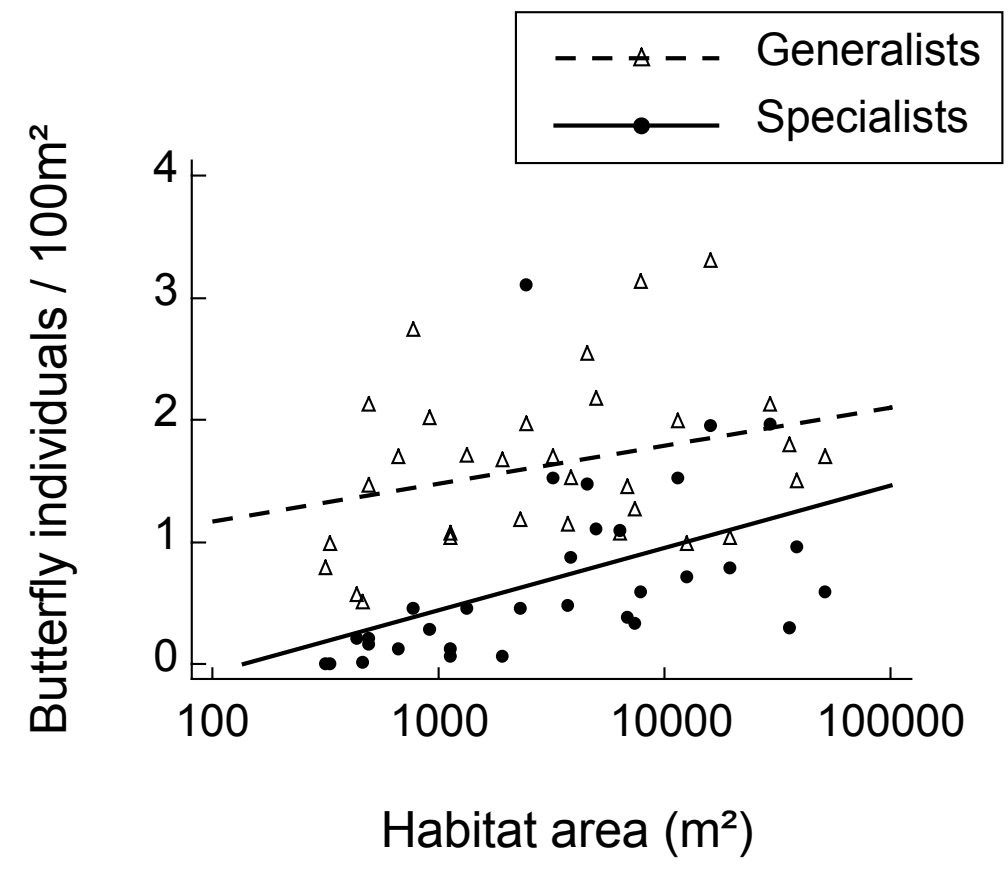

Figure 6 Relationship between the total population density of specialist and generalist butterflies and grassland area ( $n=32$ fragments). Specialist butterflies (20 species): y $=-1.09+0.51 \log _{10} \mathrm{x}$, generalist butterflies ( 34 species): $\mathrm{y}=0.55+$ $0.31 \log _{10} \mathrm{x}$. Statistics see Table 2 .

With an inclusion of cover of blooming plant species in the multiple model this factor remains for generalist density as the only explaining factor $(16.5 \%, p=0.021)$, while specialist and total density were not correlated (results not shown).

\section{DISCUSSION}

\section{Species richness of butterflies}

\section{Habitat area}

Species numbers increased significantly with increasing habitat area for both habitat specialist and habitat generalist butterflies, confirming the general validity of species-area relationships, as previously shown in similar studies of butterfly communities (Wilcox et al. 1986, Baz \& Garcia-Boyero 1995, Robertson et al. 1995, Wettstein \& Schmid 1999, Steffan-Dewenter \& Tscharntke 2000, Zschokke et al. 2000). Range of habitat area in our study was $0.03-5.14$ ha, but species-area relationships for butterflies can be found from very small scales $\left(0.25 \mathrm{~m}^{2}\right.$ to $20.25 \mathrm{~m}^{2}$, Zschokke et al. 2000) to large scales (from $100 \mathrm{~km}^{2}-3,000 \mathrm{~km}^{2}$, Wilcox et al. 1986). Not all species depend on habitat area equally as shown by Thomas et al. (1992, 2001). Habitat area influenced species richness of specialists more than that of generalists, indicating that generalists additionally use other habitat types in the surrounding landscape matrix, whereas specialists completely depend on calcareous grasslands. The $z$-value for specialists was 0.40 and thereby, higher than expected from published values for oceanic islands or 
isolated mainland habitats $(z=0.25-0.33)$, while the $z$-value for generalists was only 0.09 and even lower than those known for non-isolated mainland habitats $(z=0.13-0.18)$ (Rosenzweig 1995). This result is in support of the findings of Steffan-Dewenter and Tscharntke (2000) that monophagous habitat specialists have the highest $z$-values in a butterfly community.

\section{Habitat isolation}

In contrast to our predictions, habitat isolation did not have a consistent negative effect on butterfly species richness. This result is in support of published studies which could also not show effects of habitat isolation on butterfly species richness (Wilcox et al. 1986, Baz \& Garcia-Boyero 1995, Steffan-Dewenter \& Tscharntke 2000), but Ricketts et al. (2001) found fewer moth species in habitats with distances of $>3.5 \mathrm{~km}$ from a tropical forest reserve compared to distances $<1.0 \mathrm{~km}$. Wettstein and Schmid (1999) found more wetland indicator butterfly species when large additional wetland areas occurred nearby. In our study, only two specialist butterfly species responded negatively to habitat isolation, while Thomas et al. (1992, 2001) found that isolation affected the occurrence of all studied six butterfly species. This difference may be due to the greater range of habitat isolation in their study and the relatively low isolation in our study $(<2 \mathrm{~km})$. In addition, single species with low dispersal abilities, may suffer from even comparatively low isolation distances. Habitat isolation of calcareous grasslands as found in our study appeared to be typical for many regions in Central Europe, but the regions of Northern Europe might be more fragmented therefore causing clear isolation effects. Further, patterns found in one region may not hold for other regions due to a wealth of geographical factors changing with region (Tscharntke et al. 2001). Evidence of habitat isolation (or connectivity) may also depend on the indices used (Moilanen \& Nieminen 2002). We tested two isolation indices, the distance to the nearest grassland and an index (including a comparison of different values for the parameters $a$ and $b$ ) based on the proportion of calcareous grassland area around the habitat. None of these calculations gave evidence for any negative influence of isolation on species numbers of specialist or generalist butterflies. Summarizing, habitat connectivity of calcareous grasslands appeared to be sufficient for the butterfly communities of our German study region, although isolation has been reported to greatly affect some butterfly species in Great Britain. 


\section{Landscape context}

Effects of landscape context on species-area relationships are mostly unknown (Wiens 1997, Hanski 1999, Vandermeer \& Carvajal 2001, Tscharntke et al. 2002). In our study, landscape diversity marginally influenced species number of generalists, but not of specialists, so generalists appeared to be more affected than specialists. Landscape context influence was most important at a small spatial scale in that landscape diversity within a $250 \mathrm{~m}$ radius turned out to predict species richness best. Our findings are in support of the results of Weibull et al. (2000) for butterflies and Steffan-Dewenter et al. (2002) for bees, where smallest spatial scales predicted species richness best. In metapopulation models, based on habitat area and isolation, no improvement was achieved by adding landscape context and habitat quality (Moilanen \& Hanski 1998), whereas the models of Vandermeer and Carvajal (2001) showed that matrix quality can be of major importance for metapopulations. The weak landscape effects documented for calcareous grasslands in our study region might be explained with the relatively complex landscapes that surrounded our calcareous grasslands. Although landscape context played a minor role for butterfly species richness we found evidence for the expected tendency that generalists were more affected than specialists.

\section{Habitat quality}

Habitat quality for requirements of larvae has been predicted to be the main factor for presence or absence of butterfly species (Thomas et al. 2001). In our study we did not discriminate between the factor habitat area and the factor habitat quality, which we characterized with the number of blooming plant species and the cover of blooming plants, due to correlations between these variables. Higher habitat heterogeneity, measured as richness of blooming plants, increased with habitat area and butterfly species richness, which supports the habitat heterogeneity hypothesis (Stevens 1986, Rosenzweig 1995).

\section{Density of butterflies}

Most population density studies have been conducted for mammals and birds (Bowers \& Matter 1997, Connor et al. 2000, Matter 2000, Gaston \& Matter 2002). Empirical studies for insects are rare, especially for insect communities (Connor et al. 2000, Steffan-Dewenter \& Tscharntke 2000).

In our study, population densities increased with increasing habitat area for all butterfly and specialist butterfly species, but only marginally for generalists. Steffan-Dewenter and Tscharntke (2000) found a similar result in that specialists were more affected by habitat area 
than other species. In our study, population densities of most specialist and some generalist species increased with increasing habitat area including the three most abundant species Maniola jurtina, Polyommatus coridon, and Polyommatus icarus. This is in support of the meta-analysis of Connor et al. (2000), who assume an average increase of population densities with increasing habitat area. However, Thomas et al. (2001) found no correlations between population densities and habitat area for three butterfly species, whereas Thomas et al. (1992) found in a four-species study increasing densities for Plebeius argus and Hesperia comma (L.). Decreasing population densities with area have been recorded for Melitaea cinxia (L.) (Hanski et al. 1994). These inconsistent results may be due to the numerous difficulties in calculating relations between population density and habitat area, like the problems of including or excluding empty habitat patches and the difference between patch (PIARs) or generalized (GIARs) approaches of individual-area relationships (Gaston \& Matter 2002). The range of habitat area and the number of replicates are also important (Bowers \& Matter 1997). Matter (2000) reported for the red milkweed beetle Tetraopes tetraophthalmus (Forster) increasing, decreasing or constant densities with habitat area in different years.

We did not find correlations between population densities for butterfly communities or single species and habitat isolation, thereby confirming Steffan-Dewenter and Tscharntke (2000) and Thomas et al. (2001). However, increasing densities with decreasing isolation were reported for Melitaea cinxia (Hanski et al. 1994).

Similarly, landscape diversity had no consistent effect, and was related to only a few species. We are aware of only one other study testing butterfly densities in a landscape context. Weibull et al. (2000) reported increasing or decreasing abundances for butterflies depending on the spatial scale where landscape diversity was measured.

Summarizing, butterfly population densities were mainly affected by habitat area and not by isolation and landscape context in our study region, but generalizations are difficult due to rare and inconsistent literature data.

\section{CONCLUSIONS}

In conclusion, our data emphasize the importance of habitat area, but only a small impact of landscape diversity and no impact of habitat isolation on the butterfly community could be recorded. Habitat specialist butterflies were more affected by habitat area than habitat generalists, whereas generalists were also affected by landscape diversity. Therefore, protection of large calcareous grasslands would contribute substantially to the conservation of 
endangered habitat specialists. In contrast to expectations landscape context and habitat connectivity appeared to be sufficient for supporting species-rich butterfly communities of calcareous grasslands in our study region.

ACKNOWLEDGEMENTS We thank Konrad Fiedler, Steve Matter, Marko Nieminen, Josef Settele, Thomas Schmitt, Christian H. Schulze and one anonymous referee for helpful discussions and comments on the manuscript. We thank Hans Joger and Thomas Meineke for their butterfly advice and the following regional authorities: Niedersächsisches Landesamt für Ökologie (Reinhard Altmüller), Untere Naturschutzbehörden Stadt Göttingen (Roland Dillenburger), Landkreis Göttingen (Bertram Preuschoff), Landkreis Northeim, Landkreis Heiligenstadt, and Regierungspräsidium Kassel. This work was financially supported by the German Science Foundation (Deutsche Forschungsgemeinschaft).

\section{REFERENCES}

Baz, A., Garcia-Boyero, A. (1995) The effects of forest fragmentation on butterfly communities in central Spain. Journal of Biogeography 22, 129-140.

Bowers, M.A., Matter, S.F. (1997) Landscape ecology of mammals: relationship between density and patch size. Journal of Mammalogy 78, 999-1013.

Colwell, R.K. (1997) EstimateS: Statistical estimation of species richness and shared species from samples, Version 5, User's Guide and application published at: http://viceroy.eeb.uconn.edu/estimates.

Connor, E.F., Courtney, A.C., Yoder, J.M. (2000) Individuals-area relationships: the relationship between animal population density and area. Ecology 81, 734-748.

Erhardt, A. (1985) Wiesen und Brachland als Lebensraum für Schmetterlinge. Eine Fallstudie im Tavetsch (GR). Birkhäuser Verlag, Basel, Switzerland.

Feber, R.E., Smith, H., MacDonald, D.W. (1996) The effects on butterfly abundance of the management of uncropped edges of arable fields. Journal of Applied Ecology 33,1191-1205.

Gaston, K.J., Matter, S.F. (2002) Individuals-area relationships: comment. Ecology 83, 288-293.

GEOsat GmbH (1998) GEOlink, Version 1.46. Wuppertal, Germany.

Gonzalez, A. (2000) Community relaxation in fragmented landscapes: the relation between species richness, area and age. Ecology Letters 3, 441-448.

Hanski, I. (1999) Metapopulation ecology. Oxford University Press, New York, USA.

Hanski, I., Alho, J., Moilanen, A. (2000) Estimating the parameters of survival and migration of individuals in metapopulations. Ecology 81, 239-251. 
Hanski, I., Kuussaari, M., Nieminen, M. (1994) Metapopulation structure and migration in the butterfly Melitaea cinxia. Ecology 75, 747-762.

Harrison, S., Bruna, E. (1999) Habitat fragmentation and large-scale conservation: what do we know for sure? Ecography 22, 225-232.

Jonsen, I.D., Fahrig, L. (1997) Response of generalist and specialist insect herbivores to landscape spatial structure. Landscape Ecology 12, 185-197.

Krebs, C.J. (1989) Ecological Methodology. Harper Collins Publishers, New York, USA.

Kruess, A., Tscharntke, T. (1994) Habitat fragmentation, species loss, and biological control. Science 264, 1581-1584.

Marino, P.C., Landis, D.A. (1996) Effect of landscape structure on parasitoid diversity and parasitism in agroecosystems. Ecological Applications 6, 276-284.

Matter, S.F. (2000) The importance of the relationship between population density and habitat area. Oikos 89, 613-619.

Moilanen, A., Hanski, I. (1998) Metapopulation dynamics: effects of habitat quality and landscape structure. Ecology 79, 2503-2515.

Moilanen, A., Nieminen, M. (2002) Simple connectivity measures in spatial ecology. Ecology 83, $1131-1145$

Oates, M.R. (1995) Butterfly conservation within the management of grassland habitats. Ecology and conservation of butterflies (ed Pullin A.S.) pp. 98-112. Chapman and Hall, Suffolk, United Kingdom.

Pfaff, S., Wolters, V. (1999) The impact of agricultural management on diurnal Lepidopteran communities in a mosaic landscape. EcoSys Beiträge zur Ökosystemforschung 28, 159-167.

Pollard, E. (1977) A method for assessing changes in the abundance of butterflies. Biological Conservation 12, 115-134.

Ricketts, T.H., Daily, G.C., Ehrlich, P.R., Fay, J.P. (2001) Countryside biogeography of moths in a fragmented landscape: biodiversity in native and agricultural habitats. Conservation Biology 15, 378-388.

Robertson, P.A., Clarke, S.A., Warren, M.S. (1995) Woodland management and butterfly diversity. Ecology and conservation of butterflies (ed Pullin A.S.) pp. 113-122. Chapman and Hall, Suffolk, United Kingdom.

Rosenzweig, M.L. (1995) Species diversity in space and time. Cambridge University Press, Cambridge, United Kingdom.

Settele, J., Feldmann, R., Reinhardt, R. (1999) Die Tagfalter Deutschlands. Eugen Ulmer Verlag, Stuttgart, Germany.

Sokal, R.R.,, Rohlf, F. (1995) Biometry. Freeman, New York, USA.

Statgraphics (1995) Statgraphics plus for Windows, Version 3.0. Manugistics, Inc, Rockville, Maryland, USA. 
Steffan-Dewenter, I., Münzenberg, U., Bürger, C., Thies, C., Tscharntke, T. (2002) Scale-dependent effects of landscape context on three pollinator guilds. Ecology 83, 1421-1432.

Steffan-Dewenter, I., Münzenberg, U., Tscharntke, T. (2001) Pollination, seed set and seed predation on a landscape scale. Proceedings of the Royal Society of London Biological Sciences 268, 1685-1690.

Steffan-Dewenter, I., Tscharntke, T. (1999) Effects of habitat isolation on pollinator communities and seed set. Oecologia 121, 432-440.

Steffan-Dewenter, I., Tscharntke, T. (2000) Butterfly community structure in fragmented habitats. Ecology Letters 3, 449-456.

Stevens, G.C. (1986) Dissection of the species-area relationship among wood-boring insects and their host plants. The American Naturalist 128, 35-46.

Swengel, A.B., Swengel, S.R. (2001) Effects of prairie and barrens management on butterfly faunal composition. Biodiversity and Conservation 10, 1757-1785.

Thies, C., Tscharntke, T. (1999) Landscape structure and biological control in agroecosystems. Science 285, 893-895.

Thomas, C.D., Hanski I. (1997) Butterfly metapopulations. Metapopulation biology: ecology, genetics, and evolution (eds Hanski I., Gilpin M.E.) pp. 359-386. Academic Press, San Diego, USA.

Thomas, C.D., Thomas, J.A., Warren, M.S. (1992) Distribution of occupied and vacant butterfly habitats in fragmented landscapes. Oecologia 92, 563-567.

Thomas, J.A., Bourn, N.A.D., Clarke, R.T., Stewart, K.E., Simcox, D.J., Pearman, G.S., Curtis, R., Goodger, B. (2001) The quality and isolation of habitat patches both determine where butterflies persist in fragmented landscapes. Proceedings of the Royal Society of London Biological Sciences 268, 1791-1796.

Tscharntke, T., Steffan-Dewenter, I., Kruess, A., Thies, C. (2002) The contribution of small habitat fragments to the conservation of insect communities of grassland-cropland landscape mosaics. Ecological Applications 12, 354-363.

Tscharntke, T., Vidal, S., Hawkins, B.A. (2001) Parasitoids of grass-feeding chalcid wasps: a comparison of German and British communities. Oecologia 129, 445-451.

Vandermeer, J., Carvajal, R. (2001) Metapopulation dynamics and quality of the matrix. The American Naturalist 158, 211-220.

Van Swaay, C.A.M. (2002) The importance of calcareous grasslands for butterflies in Europe. Biological Conservation 104, 315-318.

WallisDeVries, M.F., Poschlod P., Willems J.H. (2002) Challenges for the conservation of calcareous grasslands in northwestern Europe: integrating the requirements of flora and fauna. Biological Conservation 104, 265-273. 
Warren, M.S., Hill, J.K., Thomas, J.A., Asher, J., Fox, R., Huntley, B., Roy, D.B., Telfer, M.G., Jeffcoate, S., Harding, P., Jeffcoate, G., Willis, S.G., Greatorex-Davis, J.N., Moss, D., Thomas, C.D. (2001) Rapid responses of British butterflies to opposing forces of climate and habitat change. Nature 414, 65-69.

Weibull, A.-C., Bengtsson, J., Nohlgren, E. (2000) Diversity of butterflies in the agricultural landscape: the role of farming system and landscape heterogeneity. Ecography 23, 743-750.

Wettstein, W., Schmid, B. (1999) Conservation of arthropod diversity in montane wetlands: effect of altitude, habitat quality and habitat fragmentation on butterflies and grasshoppers. Journal of Applied Ecology 36, 363-373.

Wiens, J.A. (1997) Metapopulation dynamics and landscape ecology. Metapopulation biology: ecology, genetics, and evolution (eds Hanski I., Gilpin M.E.) pp. 43-62. Academic Press, San Diego, USA.

Wilcox, B.A., Murphy, D.D., Ehrlich, P.R., Austin, G.T. (1986) Insular biogeography of the montane butterfly faunas in the Great Basin: comparison with birds and mammals. Oecologia 69, 188194.

Zschokke, S., Dolt, C., Rusterholz, H.-P., Oggier, P., Braschler, B., Thommen, G.H., Lüdin E., Erhardt A., Baur B. (2000) Short-term responses of plants and invertebrates to experimental smallscale grassland fragmentation. Oecologia 125, 559-572.

Zub, P. (1996) Die Widderchen Hessens. Mitteilungen des Internationalen Entomologischen Vereins. Supplement IV, 1-122. 


\section{APPENDIX}

Appendix: Number of individuals $(\mathrm{NoI})$ of the 54 butterfly species and the number of inhabited habitat fragments $(\mathrm{NoH})$ out of 32 calcareous grasslands (sampled in the year 2000). Multiple logistic regression for presence - absence data and Spearman rank correlations for species density are shown. The three independent habitat factors habitat area $(A)$, habitat isolation $(I)$, and landscape diversity $(L)$ as Shannon-Wiener Index on the $250 \mathrm{~m}$ radius level, were tested. $M(e)$ is the Maximum likelihood estimate, $M(p)$ is the significance level, and M (\%) the percentage of deviance explaining the model, (e) stands for Maximum likelihood estimate, $(r)$ for the Spearman rank correlation coefficient. Significance levels are: $\left.{ }^{* *} p<0.001,{ }^{* *} p<0.01, * p<0.05,{ }^{*}\right) p<0.1$, n.s. $=$ not significant. Note: positive values of $A(e, r)$ mean that the species occurrence is positively related to larger habitats, of $I$ $(e, r)$ that they profit from less isolation (= better connectivity), and $L(e, r)$ that they profit from higher landscape diversity. Only species with occurrence in $>1$ and $<32$ habitats were used for the multiple logistic regressions, and only species with a minimum of 10 individuals for the Spearman rank correlations. Habitat area and habitat isolation are $\log _{10}$ transformed.

\begin{tabular}{|c|c|c|c|c|c|c|c|c|c|c|c|}
\hline \multirow[b]{2}{*}{ Taxon } & \multirow[b]{2}{*}{ Nol } & \multirow[b]{2}{*}{$\mathrm{NoH}$} & \multicolumn{6}{|c|}{ Presence or absence data logistic regression models } & \multicolumn{3}{|c|}{$\begin{array}{l}\text { Population densities } \\
\text { Spearman rank correlations }\end{array}$} \\
\hline & & & $A(e)$ & $I(e)$ & $L(e)$ & $M(e)$ & $M(p)$ & $M(\%)$ & $A(r)$ & $I(r)$ & $L(r)$ \\
\hline \multicolumn{12}{|l|}{ Specialists: } \\
\hline Polyommatus coridon (Poda, 1761) & 2815 & 23 & $3.70^{* \star *}$ & 3.32 * & n.s. & -25.05 & 0.0002 & 40.81 & $0.63^{* \star \star}$ & n.s. & n.s. \\
\hline Coenonympha arcania (Linnaeus, 1761) & 364 & 17 & n.s. & n.s. & $3.73^{*}$ & -4.04 & 0.014 & 13.69 & n.s. & n.s. & $0.31\left(^{*}\right)$ \\
\hline Zygaena carniolica (Scopoli, 1763) & 344 & 19 & $4.92^{\star \star \star}$ & 3.60 * & n.s. & -31.33 & $<0.0001$ & 54.05 & $0.59 * \star \star$ & n.s. & n.s. \\
\hline Erynnis tages (Linnaeus, 1758) & 315 & 24 & $3.97^{\star \star \star}$ & n.s. & n.s. & -11.54 & 0.0001 & 42.61 & $0.50^{\star \star}$ & n.s. & n.s. \\
\hline Zygaena purpuralis (Brünnich, 1763) & 283 & 13 & $1.79^{\star \star}$ & n.s. & n.s. & -6.74 & 0.005 & 18.57 & $0.46^{\star \star}$ & n.s. & n.s. \\
\hline Cupido minimus (Fuessly, 1775) & 249 & 8 & $2.32^{\star \star}$ & n.s. & n.s. & -9.70 & 0.002 & 25.71 & $0.50^{\star \star}$ & n.s. & n.s. \\
\hline Zygaena viciae ([Denis \& Schiffermüller], 1775 & 167 & 14 & $1.44^{\star}$ & n.s. & n.s. & -5.35 & 0.016 & 13.22 & $0.34\left(^{*}\right)$ & n.s. & n.s. \\
\hline Thymelicus acteon (Rottemburg, 1775) & 133 & 18 & $1.18^{*}$ & n.s. & n.s. & -3.83 & 0.045 & 9.17 & n.s. & n.s. & n.s. \\
\hline Polyommatus agestis ([Denis \& Schiffermüller], 1775) & 115 & 17 & $2.47^{\star \star *}$ & n.s. & n.s. & -8.43 & 0.0003 & 29.02 & 0.49 ** & n.s. & n.s. \\
\hline Melitaea aurelia Nickerl, 1850 & 54 & 9 & $2.17^{\star \star}$ & n.s. & n.s. & -8.93 & 0.003 & 23.93 & $0.52^{\star \star}$ & n.s. & n.s. \\
\hline Erebia medusa ([Denis \& Schiffermüller], 1775) & 42 & 5 & n.s. & n.s. & n.s. & -1.69 & n.s. & - & n.s. & n.s. & n.s. \\
\hline Argynnis aglaja (Linnaeus, 1758) & 37 & 7 & $2.74^{* \star}$ & n.s. & n.s. & -11.62 & 0.001 & 31.18 & $0.50^{\star *}$ & n.s. & n.s. \\
\hline Spialia sertorius (Hoffmannsegg, 1804) & 30 & 6 & $4.79^{* \star \star}$ & n.s. & 8.42 * & -30.15 & 0.0002 & 58.41 & $0.56^{* \star}$ & n.s. & $0.37^{*}$ \\
\hline Hesperia comma (Linnaeus, 1758) & 30 & 4 & $1.83^{*}$ & n.s. & n.s. & -8.84 & 0.048 & 16.22 & $0.35\left(^{*}\right)$ & n.s. & n.s. \\
\hline Colias alfacarensis Ribbe, 1905 & 23 & 5 & $2.54^{\star \star}$ & n.s. & n.s. & -11.37 & 0.006 & 26.81 & $0.46^{\star \star}$ & n.s. & n.s. \\
\hline Zygaena hippocrepidis (Hübner, [1799]) & 21 & 4 & $1.72\left(^{*}\right)$ & n.s. & n.s. & -8.42 & 0.059 & 14.80 & $0.32(*)$ & n.s. & n.s. \\
\hline Boloria euphrosyne (Linnaeus, 1758) & 18 & 3 & n.s. & n.s. & n.s. & -2.27 & n.s. & - & n.s. & n.s. & n.s. \\
\hline Leptidea reali Reissinger, 1989 & 13 & 8 & $1.37^{*}$ & n.s. & n.s. & -6.09 & 0.042 & 11.53 & n.s. & n.s. & n.s. \\
\hline Zygaena lonicerae (Scheven, 1777) & 10 & 3 & n.s. & n.s. & n.s. & -2.27 & n.s. & & n.s. & n.s. & n.s. \\
\hline Euphydryas aurinia (Rottemburg, 1775) & 1 & 1 & - & - & - & - & - & - & - & - & - \\
\hline \multicolumn{12}{|l|}{ Generalists: } \\
\hline Maniola jurtina (Linnaeus, 1758) & 3479 & 31 & n.s. & n.s. & $28.67^{\star \star}$ & -7.80 & 0.003 & 99.71 & $0.47^{\star \star}$ & n.s. & n.s. \\
\hline Polyommatus icarus (Rottemburg, 1775) & 1226 & 30 & $14.78^{\star \star \star}$ & n.s. & $-6.30 *$ & -31.21 & 0.002 & 85.80 & 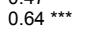 & n.s. & n.s. \\
\hline Coenonympha pamphilus (Linnaeus, 1758) & 894 & 31 & $5.62\left(^{*}\right)$ & n.s. & n.s. & -12.84 & 0.099 & 30.58 & n.s. & n.s. & n.s. \\
\hline Pieris rapae (Linnaeus, 1758) & 636 & 32 & - & - & - & - & - & - & $0.32\left(^{*}\right)$ & n.s. & n.s. \\
\hline Pieris napi (Linnaeus, 1758) & 428 & 32 & - & - & - & - & - & - & $-0.49^{\star \star}$ & n.s. & n.s. \\
\hline Zygaena filipendulae (Linnaeus, 1758) & 378 & 27 & 2.14 * & n.s. & n.s. & -5.22 & 0.023 & 18.64 & n.s. & n.s. & n.s. \\
\hline Melanargia galathea (Linnaeus, 1758) & 361 & 28 & $4.51^{\star \star}$ & n.s. & n.s. & -11.72 & 0.003 & 38.05 & 0.51 ** & n.s. & n.s. \\
\hline Pyrgus malvae (Linnaeus, 1758) & 328 & 27 & 2.60 * & n.s. & n.s. & -6.59 & 0.010 & 23.84 & $0.48^{* *}$ & n.s. & n.s. \\
\hline Aphantopus hyperantus (Linnaeus, 1758) & 292 & 31 & n.s. & n.s. & n.s. & 3.43 & n.s. & & n.s. & n.s. & n.s. \\
\hline Callophrys rubi (Linnaeus, 1758) & 254 & 20 & $2.41^{* \star *}$ & n.s. & n.s. & -7.67 & 0.0007 & 27.33 & $0.30\left(^{\star}\right)$ & n.s. & n.s. \\
\hline Nymphalis io (Linnaeus, 1758) & 247 & 31 & n.s. & -12.86 * & n.s. & 63.36 & 0.019 & 61.50 & n.s. & n.s. & n.s. \\
\hline Nymphalis urticae (Linnaeus, 1758) & 238 & 28 & n.s. & n.s. & n.s. & 1.95 & n.s. & - & n.s. & n.s. & n.s. \\
\hline Argynnis paphia (Linnaeus, 1758) & 208 & 23 & n.s. & n.s. & n.s. & 0.94 & n.s. & - & n.s. & n.s. & n.s. \\
\hline Pieris brassicae (Linnaeus, 1758) & 166 & 28 & n.s. & -5.42 * & 5.79 ** & 20.01 & 0.004 & 45.75 & n.s. & n.s. & $0.34\left(^{*}\right)$ \\
\hline Ochlodes sylvanus (Esper, [1778]) & 140 & 28 & n.s. & -5.41 * & $3.06\left(^{*}\right)$ & 22.62 & 0.016 & 34.56 & n.s. & n.s. & n.s. \\
\hline Gonepteryx rhamni (Linnaeus, 1758) & 140 & 28 & n.s. & n.s. & $3.49^{*}$ & -1.52 & 0.029 & 19.69 & n.s. & n.s. & $\left.0.311^{*}\right)$ \\
\hline Araschnia levana (Linnaeus, 1758) & 132 & 29 & n.s. & n.s. & $2.90\left(^{*}\right)$ & -0.59 & 0.087 & 14.76 & n.s. & n.s. & n.s. \\
\hline Anthocharis cardamines (Linnaeus, 1758) & 110 & 26 & n.s. & n.s. & n.s. & 1.46 & n.s. & - & n.s. & n.s. & n.s. \\
\hline Carterocephalus palaemon (Pallas, 1771) & 95 & 23 & n.s. & n.s. & 2.68 * & -1.93 & 0.048 & 10.31 & n.s. & n.s. & n.s. \\
\hline Pararge aegeria (Linnaeus, 1758) & 92 & 26 & n.s. & n.s. & n.s. & 1.47 & n.s. & - & n.s. & n.s. & n.s. \\
\hline Hamearis lucina (Linnaeus, 1758) & 62 & 17 & $2.13^{\star \star}$ & n.s. & n.s. & -7.26 & 0.001 & 23.80 & 0.41 * & n.s. & n.s. \\
\hline Thymelicus sylvestris (Poda, 1761) & 56 & 18 & n.s. & n.s. & n.s. & 0.25 & n.s. & & n.s. & n.s. & n.s. \\
\hline Plebeius argus (Linnaeus, 1758) & 40 & 5 & $1.85\left(^{\star}\right)$ & -3.19 * & n.s. & 4.65 & 0.036 & 23.96 & $0.30\left(^{*}\right)$ & -0.40 * & n.s. \\
\hline Thymelicus lineola (Ochsenheimer, 1808) & 19 & 7 & n.s. & n.s. & n.s. & -1.27 & n.s. & & n.s. & n.s. & $0.30\left(^{*}\right)$ \\
\hline Lycaena phlaeas (Linnaeus, 1761) & 19 & 7 & $1.18\left(^{*}\right)$ & n.s. & n.s. & -5.56 & 0.088 & 8.68 & $0.33\left({ }^{*}\right)$ & n.s. & n.s. \\
\hline Vanessa cardui (Linnaeus, 1758) & 15 & 8 & $1.74^{*}$ & n.s. & n.s. & -7.49 & 0.013 & 17.03 & $0.37^{\star}$ & n.s. & n.s. \\
\hline Lasiommata megera (Linnaeus, 1767) & 15 & 7 & n.s. & n.s. & n.s. & -1.27 & n.s. & - & n.s. & n.s. & n.s. \\
\hline Celastrina argiolus (Linnaeus, 1758) & 13 & 8 & $2.39^{\star *}$ & n.s. & n.s. & -9.96 & 0.002 & 26.68 & $0.47^{\star *}$ & n.s. & n.s. \\
\hline Papilio machaon Linnaeus, 1758 & 12 & 8 & n.s. & $2.35\left(^{*}\right)$ & n.s. & -11.23 & 0.094 & 7.81 & n.s. & n.s. & n.s. \\
\hline Nymphalis c-album (Linnaeus, 1758) & 11 & 8 & 1.49 * & n.s. & n.s. & -6.54 & 0.029 & 13.28 & $0.31\left(^{*}\right)$ & n.s. & n.s. \\
\hline Issoria lathonia (Linnaeus, 1758) & 5 & 3 & n.s. & $-6.45 *$ & $17.37^{\star \star}$ & 1.74 & 0.003 & 58.07 & - & - & - \\
\hline Thecla betulae (Linnaeus, 1758) & 4 & 2 & n.s. & n.s. & n.s. & -2.71 & n.s. & & - & - & - \\
\hline Limenitis camilla (Linnaeus, 1764) & 4 & 3 & 2.57 * & n.s. & n.s. & -12.24 & 0.027 & 24.61 & - & - & - \\
\hline Lycaena tityrus (Poda, 1761) & 2 & 2 & n.s. & n.s. & n.s. & -2.71 & n.s. & - & - & - & - \\
\hline
\end{tabular}




\title{
Effects of habitat area, isolation, and landscape diversity on plant species richness of calcareous grasslands
}

\begin{abstract}
Calcareous grasslands show high biodiversity and are endangered in Central Europe. We tested the relative importance of habitat area, habitat isolation, and landscape diversity for species richness and species density of vascular plants. Plants were recorded on 31 calcareous grasslands in the vicinity of the city of Göttingen (Germany) and were divided into habitat specialist and generalist species. We expected that habitat specialists are more affected by area and isolation, and habitat generalists more by landscape diversity.
\end{abstract}

In multiple regression analysis, the species number of habitat specialists $(n=66)$ and habitat generalists $(n=242)$ increased with habitat area, while habitat isolation or landscape diversity did not have significant effects. Contrary to predictions, species-area relationships of habitat specialists did not show a higher $z$-value (slope of regression line) than generalists $(z=$ 0.08 vs. $z=0.13$ ). This may have been caused by high habitat heterogeneity in large grasslands offering a microhabitat mosaic for non-specialists and by delayed extinction of long-living plant specialists in small grasslands.

Multiple regression analysis with equal sample size (= species density) on all 31 calcareous grasslands did not result in significant relations between species number and habitat area, habitat isolation or landscape diversity, thereby supporting the habitatheterogeneity, but not the area-per se hypothesis.

In conclusion, habitat area was the only predictor explaining plant species richness for both habitat specialists and generalists with adapted sample sizes. In contrast to expectations habitat isolation and landscape diversity had no effect in our study region.

KEYWORDS conservation, generalists, habitat fragmentation, specialists, species-area relationships, species density

\section{INTRODUCTION}

Great efforts were made to understand which habitat factors determine species richness and population densities (Matthies et al. 1995, Hochberg \& Ives 1999). Habitat area (Dzwonko \& Loster 1989, Zacharias \& Brandes 1990, Rejmanek \& Rosen 1992, Ouborg 1993, Kohn \& 
Walsh 1994, Grashof-Bokdam 1997, Köchy \& Rydin 1997, Honnay et al. 1999, Bruun 2000, 2001), habitat isolation (Dzwonko \& Loster 1989, van Ruremonde \& Kalkhoven 1991, Ouborg 1993, Grashof-Bokdam 1997, Honnay et al. 1999, Bruun 2000, 2001) and recently also landscape context (Kollmann \& Schneider 1999, Metzger 2000, Söderström et al. 2001, De Blois et al. 2002) were predicted and partly shown to influence plant composition of habitats. To our knowledge all three factors have never been simultaneously tested for plant species richness, with the exception of a study from Metzger (2000) in tropical forests. The influence of landscape context in habitat fragmentation studies is often ignored (Wiens 1997, Hanski 1999) although it is essential to understand plant community dynamics (De Blois et al. 2002).

It is important to note that not all species depend on habitat area, isolation and landscape context equally (Tscharntke et al. 2002). (1) Habitat specialists are more affected by habitat loss than generalists (Warren et al. 2001). (2) The surrounding landscape is inhabitable for habitat specialists, but at least partly habitable for generalists supporting the prediction that habitat isolation affects habitat specialists more than generalists (see Jonsen \& Fahrig 1997). (3) High landscape diversity in the surrounding matrix provides more different habitat types for generalists or species with other habitat preferences supporting the prediction that landscape diversity enhances the number of generalists, especially at edges, but hardly specialists (see Jonsen \& Fahrig 1997). Predictions with habitat specialists and generalists have rarely been tested for plant communities. However in related studies, plant species in forests were divided into functional groups. True forest species showed a stronger response to habitat area than other species, but no isolation effect (Honnay et al. 1999), and shade tolerant species were more sensitive to habitat fragmentation than shade intolerant species (Metzger 2000). Numerous functional groups, including specialist grassland species, were positively related to habitat area and inconsistently to isolation (Bruun 2000, 2001).

Most studies focus on the question how species-area relationships are explained. Generally three explanations for the increase of species richness with habitat area are discussed. (1) According to the sampling hypothesis, higher sampling effort results in more individuals and therefore higher species numbers (Connor \& McCoy 1979, Rosenzweig 1995, Holt et al. 1999). The sampling effect is mainly due to nested quadrate samples but may also occur in discrete habitat studies (Holt et al. 1999). (2) The habitat heterogeneity hypothesis predicts higher species numbers because of higher habitat heterogeneity. (3) The area per se or equilibrium hypothesis considers colonization - extinction dynamics to cause increasing species numbers with increasing habitat area independent of habitat diversity or sampling 
effort (Rosenzweig 1995, Holt et al. 1999). To reduce the sampling effect, complete surveys of habitats (Rosenzweig 1995) or equal sample sizes on all habitats (Kelly et al. 1989, Holt et al. 1999) are possible. Habitat area and habitat diversity are often closely correlated (Kohn \& Walsh 1994, Rosenzweig 1995, Köchy \& Rydin 1997). Equal sample sizes should also reduce the habitat diversity effect, making it possible to test separately for area-per se effects (Kelly et al. 1989, Köchy \& Rydin 1997).

Most plant studies on habitat fragmentation were carried out in woodlands (e.g. Dzwonko \& Loster 1989, Ruremonde \& Kalkhoven 1991, Saetersdal 1994, Grashof-Bokdam 1997, Lawesson et al. 1998, Honnay et al. 1999, Metzger 2000), while grasslands are less commonly studied (Rejmanek \& Rosen 1992, Ouborg 1993, Bruun 2000, 2001, Zschokke et al. 2000). Our study was conducted on calcareous grasslands, which belong to the most species-rich plant and insect habitats in Central Europe (Van Swaay 2002). Habitat loss of calcareous grasslands in Germany reaches locally up to $60 \%$ in the last 100 years, driving 1 $\%$ plant species restricted to this habitat type to extinction and $42 \%$ to be threatened in Germany (WallisdeVries et al. 2002). Calcareous grasslands are endangered in Germany and protected by law (Riecken et al. 1994). Interest in conservation is high (Beinlich \& Plachter 1995, WallisDeVries et al. 2002), leading to several studies on plant and insect community structure and extinction risks (e.g. Fischer \& Stöcklin 1997, Bruun 2000, 2001, SteffanDewenter \& Tscharntke 2000, Zschokke et al. 2000, Moog et al. 2002).

In this study we tested the impact of the three parameters habitat area, habitat isolation, and landscape diversity on the species richness of habitat specialist and generalist vascular plants on calcareous grasslands.

We tested the following predictions:

(1) Plant species richness increases with increasing habitat area, decreasing habitat isolation and increasing landscape diversity.

(2) Species richness of habitat specialists is more sensitive to habitat area and isolation, whereas species richness of generalists is more sensitive to landscape diversity.

(3) Species density, i.e. plant species richness per area in samples of equal size on all study sites, is related to habitat area, isolation and landscape diversity.

\section{MATERIALS AND METHODS}

\section{Study region and study sites}

Altogether 31 calcareous grasslands in the vicinity of the city of Göttingen in Lower Saxony (Germany) were studied. The grasslands were located in the Leine-Weser Mountain lands 
(Gauss-Krüger: $R=5,695, H=3,550 / R=5,724, H=3,579)$ and belong to the plant association Gentiano-Koelerietum. Low impact management to stop succession and to remove woody bushes were carried out on the study sites mainly from late summer to winter. The average rainfall in the area around Göttingen is $635 \mathrm{~mm}$ per annum, with an average temperature of $6.8^{\circ} \mathrm{C}$ (Deutscher Wetterdienst 2001). The landscape is structurally rich with a mosaic of diverse habitat types. Calcareous grasslands can be sharply delimited from the surrounding landscape with little or no ambiguity and cover $0.26 \%$ of the study region.

\section{Habitat area, isolation, landscape diversity}

The area of the 31 calcareous grasslands was measured with a differential GPS GEOmeter 12L (GEOsat GmbH 1998) and ranged from 314 to 51,395 $\mathrm{m}^{2}$. Area covered with shrubs was excluded in the measurement.

Habitat isolation was measured as an index ( $I)$ of each study site ( $i$ ) from edge-to-edge on the basis of all known calcareous grasslands in a radius of $8 \mathrm{~km}$ around our study sites using the following formula:

$I=\Sigma \mathrm{e}^{-d i j} A_{j}$

where $A_{j}$ is the size (in $\mathrm{m}^{2}$ ) of neighbouring calcareous grasslands and dij the distance (in $\mathrm{km}$ ) from the neighbouring grassland $j$ to the study site $i$. The formula is based on Hanski et al. (1994). Larger values of $I$ indicate lower isolation than smaller values. Additionally, habitat isolation was measured as distance from edge to edge to the nearest calcareous grassland (55 $-1,894 \mathrm{~m}$ ). This isolation distance and the isolation index were always $\log _{10}$ transformed. Both were correlated $(r=-0.445, n=31, P=0.012)$ and showed similar always nonsignificant results. Therefore we show only the results from the isolation index.

Landscape diversity was analysed using modified digital thematic maps (ATKIS ${ }^{\circledR}$ DLM 25/1 Landesvermessung and Geobasisinformationen Niedersachsen 1991 - 1996, and ATKIS®-DLM 25/2 Hessisches Landesvermessungsamt 1996). Eleven land-use types were defined, including arable land (42.15\% of the study region), forest (36.80\%), grassland $(12.14 \%)$, built-up area $(6.24 \%)$, other habitats $(1.48 \%)$, garden land $(0.31 \%)$, hedgerow $(0.30 \%)$, calcareous grassland $(0.26 \%)$, orchard meadow $(0.20 \%)$, plantation $(0.06 \%)$, and fen $(0.05 \%)$. We used the Shannon-Wiener index to calculate landscape diversity for each of the 31 grassland fragments using a nested set of 12 circles with a radius ranging from $0.25 \mathrm{~km}$ to $3.00 \mathrm{~km}$ in $0.25 \mathrm{~km}$ steps:

$H s=-\Sigma p_{i} * \ln p_{i}$ 
where $p_{i}$ is the proportion of each of the eleven different land-use types (Krebs 1989).

Further we pooled the plant species rich habitat types, grassland, garden land, hedgerow, calcareous grassland, orchard meadow, and fen around the study sites. We related the different plant species richness data with the proportion of these pooled habitat type data set. We did never find any positively significant relation between both, and the pooled habitat types were highly correlated with landscape diversity (250m scale: $r=0.685, P<0.0001)$. Therefore we only show results from landscape diversity.

Due to a few missing ATKIS data we could test the landscape data for a radius of 0.25 and $0.50 \mathrm{~km}$ for all 31 study sites, while $0.75-2.00 \mathrm{~km}$ scales were tested for only $30,2.25$ $\mathrm{km}$ for 29 , and $2.50-3.00 \mathrm{~km}$ for 28 sites. For each landscape analysis, the habitat area of the central study site was excluded.

\section{Plants}

The complete survey of vascular plants (Spermatophyta plus Equisetum arvense L.) for all of the 31 calcareous grasslands was compiled from four independent data sets from 1996, 2000 and 2001 to achieve a total list of plant species per study site. In 1996 and 2000 the vegetation was mapped in May/June and again in August in randomised plots of $25 \mathrm{~m}^{2}$ according to Braun-Blanquet. These plots were the same for both records in 1996, while they changed in 2000. In 1996 one plot was mapped for small $\left(<1,500 \mathrm{~m}^{2}\right)$, two plots for medium $(1,500-$ $\left.5,000 \mathrm{~m}^{2}\right)$, three plots for medium to large $\left(5,000 \mathrm{~m}^{2}-10,000 \mathrm{~m}^{2}\right)$ and four plots for large grasslands $\left(>10,000 \mathrm{~m}^{2}\right)$ (see Steffan-Dewenter \& Tscharntke 2000). In 2000 one plot was mapped on small grasslands $\left(<1,500 \mathrm{~m}^{2}\right)$, two plots on medium grasslands $(1,500-10,000$ $\left.\mathrm{m}^{2}\right)$, and three plots on large grasslands $\left(>10,000 \mathrm{~m}^{2}\right)$. To complete these two Braun-Blanquet surveys we mapped in 2000 five times between April and August the blooming plants of each grassland on randomised transects. Each transect covered from $11.4 \%$ (largest habitat) to $100.0 \%$ (small habitats) of the total habitat area (average: $62.7 \pm 0.4 \%$ ). In a fourth survey in May 2001, again plants were mapped on the 31 grasslands to complete the species list.

We used the total number of species per grassland for statistical analyses. To compare equal sample sizes (species density) we also tested all correlations using only one $25 \mathrm{~m}^{2}$ plot (mapped in spring and summer) of the 2000 data set.

All vascular plant species recorded as species restricted to oligotrophic grasslands in Von Drachenfels (1994) were defined as habitat specialists $(n=66)$ for calcareous grasslands (see Appendix). These species mainly occur on calcareous grasslands in the study region, but might inhabit other habitat types in other regions of Germany and Europe. All other species 
with no habitat preferences or preferences for other habitats were defined as generalist plants (242 species). Species identification and nomenclature follow Bässler et al. (1999).

\section{Statistical analyses}

The statistical analyses of the data were performed using the software "Statgraphics Plus for Windows 3.0" (Statgraphics 1995). All data were tested whether they satisfy the assumption of normality. We calculated simple and multiple regressions, Pearson correlations, and comparisons of regression lines (Sokal \& Rohlf 1995). We chose backward selections for stepwise multiple regressions. The independent variables habitat area and isolation were always $\log _{10}$ transformed. Species numbers in regressions were also $\log _{10}$ transformed to calculate scale-independent slopes ( $z$-values) for comparison with other studies. Arithmetic means \pm one standard error are given in the text.

\section{RESULTS}

Habitat area (0.03 - 5.14 ha, average: $0.90 \pm 0.23$ ha) was not correlated with habitat isolation (index: 2,051 - 85,978, average: $23,019 \pm 3,368)(r=-0.013, P=0.944)$. Also landscape diversity (at a $250 \mathrm{~m}$ scale; Shannon Wiener: 0.09 - 1.56, average: $1.09 \pm 0.05$ ) was not correlated with habitat isolation $(r=-0.015, P=0.936)$, but with habitat area $(r=0.375, P=$ $0.038)$.

Altogether 308 plant species were identified on all 31 calcareous grasslands with pooled data. This was an average of $89.0 \pm 3.7$ species per habitat with a minimum of 56 species and a maximum of 138 species. In Braun-Blanquet plots we found 192 species in 1996 and 234 species in 2000, resulting in a total of 278 species. Additional recordings due to the transect walks in 2000 and the survey in 2001 resulted in a total of 308 species. Nine of 66 (13.6\%) specialist species (see Appendix) and seven out of 242 (2.9\%) habitat generalist species (Achillea millefolium L., Campanula rotundifolia L., Daucus carota L., Leontodon hispidus L., Lotus corniculatus L., Plantago lanceolata L., Plantago media L.) were found on each of the 31 calcareous grasslands.

Species richness increased with increasing habitat area for both habitat specialist and generalist species leading to an increase of all species (Fig. 1, Table 1). The $z$-value (slope of $\log$-log regressions) for specialists (z-value: 0.08) was lower than for generalists (z-value: 0.13 ), but did not differ significantly (comparison of regression lines $F=2.16, P=0.148$ ). The slope for not log-transformed species numbers was even significantly steeper for 
generalists (comparison of regression lines $F=5.34, P=0.024$ ). For all plant species the $z$ value was 0.11. Habitat isolation showed no significant effect on species richness in simple regressions, while landscape diversity at the smallest scale of $250 \mathrm{~m}$ was positively related to specialist species with marginal significance (Table 1). We analyzed the effects of landscape diversity at 12 nested spatial scales. Correlations were highest at the smallest spatial scale of $250 \mathrm{~m}$ for specialist, generalist and all plants (results for other spatial scales are not shown).

In multiple regressions with habitat area, isolation and landscape diversity $(250 \mathrm{~m})$, habitat area was the only significant factor explaining $44.8 \%$ of variation for specialists, $37.2 \%$ for generalists and $46.0 \%$ for all plant species.

Table 1 Simple regressions for the habitat specialists among the plant species (66 species), generalist species (242 species) and all plant species (308 species). Relations between species numbers and species density with the three independent factors habitat area, habitat isolation, and landscape diversity $(n=31)$. Habitat area and habitat isolation are $\log _{10}$ transformed.

\begin{tabular}{l|l|l|l|l|l|l|l|l|l}
$\begin{array}{l}\text { Total species } \\
\text { numbers }\end{array}$ & \multicolumn{3}{|l|}{ Habitat area } & \multicolumn{3}{l|}{ Habitat isolation } & \multicolumn{3}{l}{$\begin{array}{l}\text { Landscape diversity } \\
\text { (Radius: 250m) }\end{array}$} \\
\hline & $F$ & $r$ & $P$ & $F$ & $r$ & $P$ & $F$ & $r$ & $P$ \\
Habitat specialists & 23.49 & 0.669 & $<0.0001$ & 0.39 & -0.116 & 0.536 & 3.81 & 0.341 & 0.061 \\
Habitat generalists & 17.18 & 0.610 & 0.0003 & 0.95 & -0.178 & 0.337 & 0.16 & 0.074 & 0.692 \\
All plants & 24.67 & 0.678 & $<0.0001$ & 1.04 & 0.186 & 0.316 & 0.76 & 0.160 & 0.390
\end{tabular}

\begin{tabular}{|c|c|c|c|c|c|c|c|c|c|}
\hline \multirow[t]{2}{*}{ Species density } & \multicolumn{3}{|c|}{ Habitat area } & \multicolumn{3}{|c|}{ Habitat isolation } & \multicolumn{3}{|c|}{$\begin{array}{l}\text { Landscape diversity } \\
\text { (Radius: } 250 \mathrm{~m} \text { ) }\end{array}$} \\
\hline & $F$ & $r$ & $P$ & $F$ & $r$ & $P$ & $F$ & $r$ & $P$ \\
\hline Habitat specialists & 0.09 & 0.054 & 0.773 & 0.39 & -0.116 & 0.535 & 0.00 & -0.008 & 0.965 \\
\hline Habitat generalists & 0.02 & 0.028 & 0.879 & 0.00 & 0.012 & 0.950 & 0.00 & 0.004 & 0.981 \\
\hline All plants & 0.06 & 0.046 & 0.807 & 0.11 & 0.061 & 0.744 & 0.00 & -0.000 & 0.999 \\
\hline
\end{tabular}

Considering only equal sample size with one plot per grassland, we found altogether 199 plant species. This was an average of $46.5 \pm 1.4$ species per habitat with a minimum of 30 species and a maximum of 63 species. Neither in simple (Table 1) nor in multiple regressions we found evidence for an impact of habitat area, isolation, and landscape diversity on plant 
species density for specialists, generalists or all plants on the studied 31 calcareous grasslands.

A)

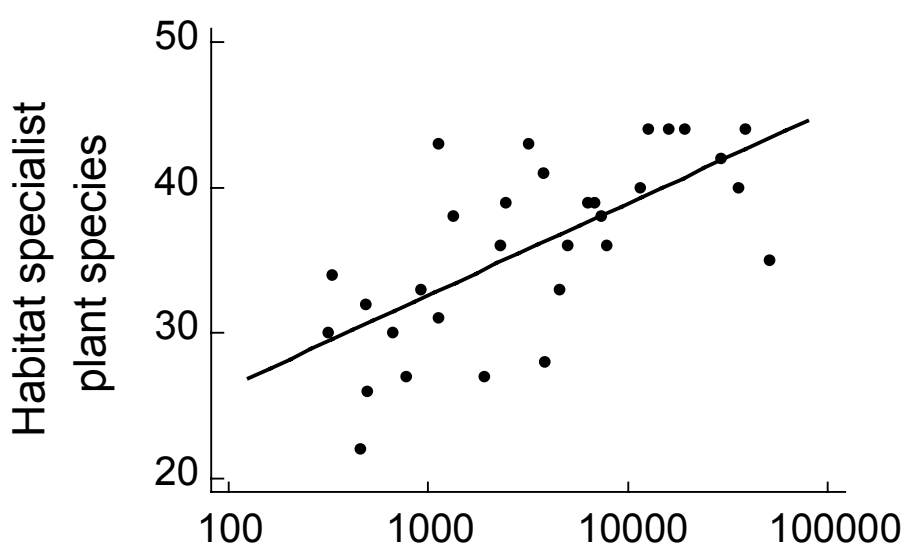

Habitat area $\left(\mathrm{m}^{2}\right)$

B)

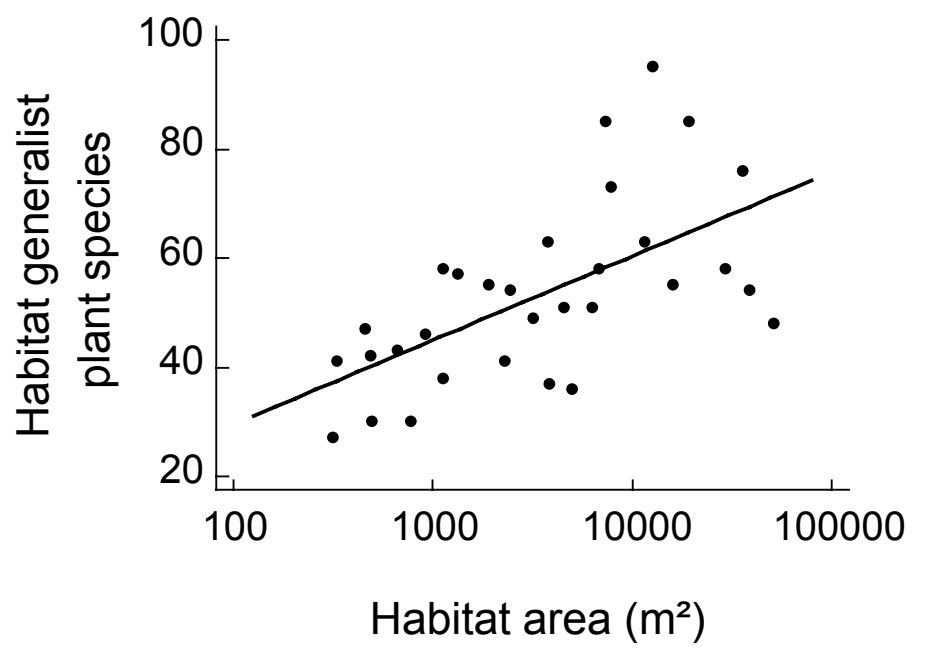

Figure 1 Relationship between the number of plant species and grassland area $(n=31$ fragments).

A) Specialist plant species (66 species): $\mathrm{y}=13.64+6.32 \log _{10}$ $\mathrm{x}$.

B) Generalist plant species $(242$ species): $\mathrm{y}=-1.40+15.44 \log _{10}$ $\mathrm{x}$. Statistics see Table 1 . Comparison of regression lines: slopes: $F=5.34, P=0.024$.

\section{DISCUSSION}

Landscape diversity increase generalist insect species numbers (Jonsen \& Fahrig 1997, unpublished data, J. Krauss), but contrary to these findings landscape diversity did not affect the number of generalist plants in our study. Instead, increasing landscape diversity even tended to increase specialist plant species numbers, but due to correlation with habitat area this effect was eliminated in multiple regressions. In a related study Söderström et al. (2001) 
could find lower plant species numbers on semi-natural pastures with increasing proportion of arable fields in the surrounding landscape, but landscape diversity was not studied. We could not detect an effect of landscape on total plant species richness in our study region. This might be explained with the relatively complex landscapes that surrounded our calcareous grasslands. In multiple tests for different landscape parameters and numerous functional groups inconsistent results of correlations of plant species richness with landscape diversity were reported (Kollman \& Schneider 1999, Metzger 2000). To reduce multiple testing and intercorrelations of landscape factors, Steffan-Dewenter et al. (2002) suggest focusing on landscape diversity and proportion of habitats in the surrounding matrix. In general landscape studies on plant species composition are still rare, but essential to fully understand community dynamics (De Blois et al. 2002).

Species numbers increased significantly with increasing habitat area for both habitat specialist and habitat generalist plant species. Our results confirm the general validity of species-area relationships, as shown before with plant communities of forests (Dzwonko \& Loster 1989, Zacharias \& Brandes 1990, Van Ruremonde \& Kalkhoven 1991, Saetersdal 1994, Grashof-Bokdam 1997, Honnay et al. 1999) and other habitats (Usher 1979, Rejmanek \& Rosen 1992, Ouborg 1993, Kohn \& Walsh 1994, Köchy \& Rydin 1997, Bruun 2000, 2001). Our high sampling effort appeared to guarantee almost complete recordings. In addition, our numbers of plant species on 27 of the grasslands were very similar to a complete survey made between 1980 and 1986 (Eggers 1986, unpublished data, personal communication B. Preuschoff). We did not measure habitat heterogeneity, but species density, i.e. species numbers measured with equal sample sizes on all grasslands, was not affected by habitat area in our study, giving indirect evidence for the habitat heterogeneity hypothesis as explanation for species-area relations (Kelly et al. 1989, Holt et al. 1999). Habitat heterogeneity is assumed to be the main predictor for plant species richness (Köchy \& Rydin 1997), as neither Köchy and Rydin (1997) nor Lawesson et al. (1998) found positive species-area relations for area-corrected sample sizes.

The $z$-value (slopes of log-log species-area regressions) for specialist plant species was 0.08 , and for generalists 0.13 . Other reported $z$-values for vascular plants on mainland habitats are between 0.18 and 0.24 (Dzwonko \& Loster 1989, Rejmanek \& Rosen 1992, Köchy \& Rydin 1997) and are generally lower compared to the next trophic level, the herbivores (e.g. Holt et al. 1999, Steffan-Dewenter \& Tscharntke 2002).

Surprisingly, habitat specialists were not more affected by habitat area than generalists. This is in contrast to previous findings for specialist and generalist plant species, where the $z$ - 
value was higher for true forest plant species $(z=0.45)$ than for species of edges and clearings $(z=0.39)$ and for woody species and lianas $(z=0.17)$ in Belgium forests (Honnay et al. 1999). Also habitat specialist butterflies on the same calcareous grasslands were significantly more affected by habitat loss than generalists (unpublished data, J. Krauss). Large areas with high habitat heterogeneity can be expected to offer a diverse mosaic of microhabitat types for species that are non-specialists. This may explain steeper species-area relationships for generalists in our study. Habitat specialists are expected to have higher extinction rates than generalists as shown for plants and butterflies (Fischer \& Stöcklin 1997, unpublished data, J. Krauss). However when these specialists are perennial plants, they may persist for several years in small populations, thereby delaying their extinction (Oostermeijer et al. 1994). An extinction debt for these species in small habitats keep the $z$-value lower than in equilibrium situations (Tilman et al. 1994, Gonzales 2000). Hypotheses developed for mobile birds and butterflies with short life cycles might be not acceptable for sessile plants with long life cycles (Eriksson 1996).

Contrary to our predictions we could not find effects of habitat isolation, neither for specialist nor for generalist plant species. Isolation effects on plant species are mainly found for plant species with low dispersal abilities (Dzwonko \& Loster 1989, Van Ruremonde \& Kalkhoven 1991, Grashof-Bokdam 1997), while other species groups generally show no or weak isolation effects (Ouborg 1993, Köchy \& Rydin 1997, Honnay et al. 1999, Bruun 2000, 2001). Also for the more mobile butterfly species no isolation effects could be reported on the same calcareous grasslands (Steffan-Dewenter \& Tscharntke 2000, unpublished data, J. Krauss). As calcareous grasslands were better connected decades ago (WallisDeVries et al. 2002), we might found patterns that show previous situations because of extinction debt of plants, and therefore no isolation effect.

In conclusion, habitat area was the only predictor explaining vascular plant community structure for habitat specialist, generalist, and all plant species. In contrast to expectations, habitat isolation and landscape diversity had no effect in our study region. These results stress the point, that habitat area is the most important basis of plant diversity. Several populations of specialist plant species on small habitat fragments may be prone to extinction in the near future showing the so-called extinction debt, so the present $z$-values may give a too positive picture. 
ACKNOWLEDGEMENTS We thank David Kleijn, Olivier Honnay and Sabine Güsewell for helpful comments on the manuscript and Bertram Preuschoff (Untere Naturschutzbehörde des Landkreis Göttingen) for his expert advice. This work was financially supported by the German Science Foundation (Deutsche Forschungsgemeinschaft).

\section{REFERENCES}

Bässler M., Jäger E.J., Werner K. (1999) Rothmaler, Exkursionsflora von Deutschland, Bd. 2, Gefässpflanzen: Grundband. Spektrum Akademischer Verlag, Heidelberg, Berlin, Germany.

Beinlich B., Plachter H. (1995) Ein Naturschutzkonzept für Kalkmagerrasen der Mittleren Schwäbischen Alb (Baden-Württemberg): Schutz, Nutzung und Entwicklung. Beihefte zu den Veröffentlichungen für Naturschutz und Landschaftspflege in Baden-Württemberg 83, 1-520.

Bruun H.H. (2000) Patterns of species richness in dry grassland patches in an agricultural landscape. Ecography 23, 641-650.

Bruun H.H. (2001) Determinants of species richness in patches of grassland and heathland in Himmerland (Denmark). Nordic Journal of Botany 21, 607-614.

Connor E.F., McCoy E.D. (1979) The statistics and biology of the species-area relationship. The American Naturalist 113, 791-833.

De Blois S., Domon G., Bouchard A. (2002) Landscape issues in plant ecology. Ecography 25, 244256.

Deutscher Wetterdienst (2001) Klimadaten der Wetterstation Göttingen. In: Stadt Göttingen, Amt für Statistik und Stadtforschung. (eds), Statistikjournal 1/2001.

Dzwonko Z., Loster S. (1989) Distribution of vascular plant species in small woodlands on the Western Carpathian foothills. Oikos 56, 77-86.

Eriksson O. (1996) Regional dynamics of plants: a review of evidence for remnant, source-sink and metapopulations. Oikos 77, 248-258.

Fischer M., Stöcklin J. (1997) Local extinctions of plants in remnants of extensively used calcareous grasslands 1950-1985. Conservation Biology 11, 727-737.

GEOsat GmbH (1998) GEOlink Version 1.46. Wuppertal, Germany.

Gonzalez A. (2000) Community relaxation in fragmented landscapes: the relation between species richness, area and age. Ecology Letters 3, 441-448.

Grashof-Bokdam C. (1997) Forest species in an agricultural landscape in the Netherlands: effects of habitat fragmentation. Journal of Vegetation Science 8, 21-28.

Hanski I. (1999) Metapopulation ecology. Oxford University Press, United Kingdom.

Hanski I., Kuussaari M., Nieminen M. (1994) Metapopulation structure and migration in the butterfly Melitaea cinxia. Ecology 75, 747-762. 
Hochberg M.E., Ives A.R. (1999) Can natural enemies enforce geographical range limits? Ecography 22, 268-276.

Holt R.D., Lawton J.H., Polis G.A., Martinez N.D. (1999) Trophic rank and species-area relationship. Ecology 80, 1495-1504.

Honnay O., Endels P., Vereecken H., Hermy M. (1999) The role of patch area and habitat diversity in explaining native plant species richness in disturbed suburban forest patches in northern Belgium. Diversity and Distribution 5, 129-141.

Jonsen I.D., Fahrig L. (1997) Response of generalist and specialist insect herbivores to landscape spatial structure. Landscape Ecology 12, 185-197.

Kelly B.J., Bastow Wilson J., Mark A.F. (1989) Causes of the species-area relation: a study of islands in lake Manapouri, New Zealand. Journal of Ecology 77, 1021-1028.

Köchy M., Rydin H. (1997) Biogeography of vascular plants on habitat islands, peninsulas and mainlands in an east-central Swedish agricultural landscape. Nordic Journal of Botany 17, 215-223.

Kohn D.D., Walsh D.W. (1994) Plant species richness - the effect of island size and habitat diversity. Journal of Ecology 82, 367-377.

Kollmann J., Schneider B. (1999) Landscape structure and diversity of fleshy-fruited species at forest edges. Plant Ecology 144, 37-48.

Krebs C. J. (1989) Ecological Methodology. Harper Collins Publishers, USA.

Lawesson J.E., de Blust G., Grashof C., Firbank L., Honnay O., Hermy M., Hobitz P., Jensen L.M. (1998) Species diversity and area-relationships in Danish beech forests. Forest Ecology and Management 106, 235-245.

Matthies D., Schmid B., Schmid-Hempel P. (1995) The importance of population processes for the maintenance of biological diversity. Gaia 4, 199-209.

Metzger J.P. (2000) Tree functional group richness and landscape structure in a Brazilian tropical fragmented landscape. Ecological Applications 10, 1147-1161.

Moog D., Poschlod P., Kahmen S., Schreiber K.F. (2002) Comparison of species composition between different grassland management treatments after 25 years. Applied Vegetation Science 5, 99106.

Oostermeijer J.G.B., Vant`t Veer R., Den Nijs J.C.M. (1994) Population structure of the rare, longlived perennial Gentiana pneumonanthe in relation to vegetation and management in the Netherlands. Journal of Applied Ecology 31, 428-438.

Ouborg N.J. (1993) Isolation, population size and extinction: the classical and metapopulation approaches applied to vascular plants along the Dutch Rhine-system. Oikos 66, 298-308.

Rejmanek M., Rosen E. (1992) Influence of colonizing shrubs on species-area relationships in alvar plant communities. Journal of Vegetation Science 3, 625-630. 
Riecken U., Ries U., Ssymank, A. (1994) Rote Liste der gefährdeten Biotoptypen der Bundesrepublik Deutschland. Kilda-Verlag, Germany.

Rosenzweig M.L. (1995) Species diversity in space and time. Cambridge University Press, United Kingdom.

Saetersdal M. (1994) Rarity and species/area relationships of vascular plants in deciduous woods, western Norway - applications to nature reserve selection. Ecography 17, 23-38.

Söderström B., Svensson B., Vessby K., Glimskär A. (2001) Plants, insects and birds in semi-natural pastures in relation to local habitat and landscape factors. Biodiversity and Conservation 10, 1839-1863.

Sokal R. R., Rohlf F. (1995) Biometry. Freeman, NY, USA.

Statgraphics (1995) Statgraphics plus for Windows, Version 3.0. Manugistics, Inc, Rockville, MD, USA.

Steffan-Dewenter, I., Münzenberg U., Bürger C., Thies C., Tscharntke, T. (2002) Scale-dependent effects of landscape context on three pollinator guilds. Ecology 83, 1421-1432.

Steffan-Dewenter I., Tscharntke T. (2000) Butterfly community structure in fragmented habitats. Ecology Letters 3, 449-456.

Steffan-Dewenter I., Tscharntke T. (2002) Insect communities and biotic interactions on fragmented calcareous grasslands a mini review. Biological Conservation 104, 275-284.

Tilman D., May R.M., Lehman C.L., Nowak M.A. (1994) Habitat destruction and the extinction debt. Nature 371, 65-66.

Tscharntke T., Steffan-Dewenter I., Kruess A., Thies C. (2002) Characteristics of insect populations on habitat fragments: A mini review. Ecological Research 17, 229-239.

Usher M.B. (1979) Changes in the species-area relations of higher plants on nature reserves. Journal of Applied Ecology 16, 213-215.

Van Ruremonde R.H.A.C., Kalkhoven J.T.R. (1991) Effects of woodlot isolation on the dispersion of plants with fleshy fruits. Journal of Vegetation Science 2, 377-384.

Van Swaay C.A.M. (2002) The importance of calcareous grasslands for butterflies in Europe. Biological Conservation 104, 315-318.

Von Drachenfels O. (1994) Kartierschlüssel für Biotoptypen in Niedersachsen. Naturschutz und Landschaftspflege Niedersachsen 4, 1-192.

WallisDeVries M.F., Poschlod P., Willems, J.H. (2002) Challenges for the conservation of calcareous grasslands in northwestern Europe: integrating the requirements of flora and fauna. Biological Conservation 104, 265-273.

Warren M.S., Hill J.K., Thomas J.A., Asher J., Fox R., Huntley B., Roy D.B., Telfer M.G., Jeffcoate S., Harding P., Jeffcoate G., Willis S.G., Greatorex-Davis J.N., Moss D., Thomas C.D. (2001) Rapid responses of British butterflies to opposing forces of climate and habitat change. Nature 414, 65-69. 
Wiens J.A. (1997) Metapopulation dynamics and landscape ecology. Metapopulation biology: ecology, genetics, and evolution (eds Hanski, I., Gilpin, M.E.), pp. 43-62 Academic Press, London.

Zacharias D., Brandes D. (1990) Species area-relationships and frequency - floristical data analysis of 44 isolated woods in northwestern Germany. Vegetatio 88, 21-29.

Zschokke S., Dolt C. Rusterholz, H.-P. Oggier, P. Braschler B., Thommen, G.H., Lüdin, E., Erhardt, A., Baur, B. (2000) Short-term responses of plants and invertebrates to experimental smallscale grassland fragmentation. Oecologia 125, 559-572. 


\section{APPENDIX}

Appendix Habitat specialist plants on 31 calcareous grasslands in Southern Lower Saxony.

\begin{tabular}{|c|c|c|c|}
\hline Taxon & $\begin{array}{c}\text { Number of } \\
\text { occupied } \\
\text { habitats }\end{array}$ & Taxon & $\begin{array}{c}\text { Number of } \\
\text { occupied } \\
\text { habitats }\end{array}$ \\
\hline Agrimonia eupatoria $\mathrm{L}$. & 30 & Koelaeria pyramidata (Lamk.) P.B. & 29 \\
\hline Anemone sylvestris L. & 3 & Medicago falcata $\mathrm{L}$. & 7 \\
\hline Anthyllis vulneraria L. & 20 & Medicago lupulina $\mathrm{L}$. & 30 \\
\hline Astragalus glycyphyllos L. & 10 & Melampyrum arvense $\mathrm{L}$. & 3 \\
\hline Avenula pratensis (L.) Dum. & 16 & Melampyrum nemorosum L. & 2 \\
\hline Avenula pubescens (HUDS.) Dum. & 11 & Onobrychis viciifolia Scop. & 7 \\
\hline Brachypodium pinnatum (L.) P.B. & 31 & Ononis spinosa $\mathrm{L}$. & 24 \\
\hline Briza media $\mathrm{L}$. & 30 & Ophris apifera Huds. & 1 \\
\hline Bromus erectus Huds. & 19 & Ophrys insectifera L. em L. & 16 \\
\hline Campanula rapunculoides $\mathrm{L}$. & 24 & Orchis mascula (L.) L. & 13 \\
\hline Carex caryophyllea Latourr. & 15 & Orchis militaris L. & 3 \\
\hline Carex flacca Schreber & 30 & Orchis purpurea Huds. & 5 \\
\hline Carex ornithopoda Willd. & 3 & Orchis tridentata Scop. & 3 \\
\hline Carlina vulgaris $\mathrm{L}$. & 25 & Origanum vulgare L. & 3 \\
\hline Centaurea scabiosa L. & 28 & Pimpinella saxifraga $\mathrm{L}$. & 31 \\
\hline Cerastium arvense $\mathrm{L}$. & 11 & Platanthera bifolia (L.) L.C. Richard & 2 \\
\hline Cirsium acaule SCOP. & 31 & Polygala comosa Schkuhr & 27 \\
\hline Clinopodium vulgare L. & 15 & Potentilla neumanniana Rchb. & 31 \\
\hline Euphorbia cyparissias L. & 14 & Primula veris L. & 30 \\
\hline Euphrasia stricta Wolff ex Lehm & 2 & Prunella grandiflora (L.) Scholler & 11 \\
\hline Festuca ovina L. & 31 & Ranunculus bulbosus L. & 31 \\
\hline Filipendula vulgaris Moench & 1 & Salvia pratensis L. & 4 \\
\hline Fragaria viridis (Duchesne) Weston & 18 & Sanguisorba minor Scop. & 31 \\
\hline Galium pumilum Murray & 22 & Scabiosa columbaria L. & 31 \\
\hline Galium verum $\mathrm{L}$. & 25 & Sedum sexangulare $\mathrm{L}$. & 6 \\
\hline Gentianella ciliata (L.) Borkh. & 10 & Silene nutans L. & 3 \\
\hline Gentianella germanica (Willd.) Börner & 9 & Thymus pulegioides L. & 31 \\
\hline Gymnadenia conopsea (L.) R.Br. & 26 & Trifolium campestre Schreber & 7 \\
\hline Helianthemum nummularium (L) & 20 & Trifolium medium L. & 18 \\
\hline Hieracium pilosella $\mathrm{L}$. & 29 & Trifolium montanum L. & 2 \\
\hline Hippocrepis comosa $\mathrm{L}$. & 25 & Veronica teucrium L. & 17 \\
\hline Hypericum perforatum $\mathrm{L}$. & 30 & Vincetoxicum hirundinaria Med. & 3 \\
\hline Inula conyzae (Griesselich) Meikle & 12 & Viola hirta $\mathrm{L}$. & 26 \\
\hline
\end{tabular}




\title{
Effects of habitat fragmentation on the genetic structure of the monophagous butterfly Polyommatus coridon along its northern range margin
}

\begin{abstract}
Population genetic patterns of species at their range margin have important implications for species conservation. We performed allozyme electrophoresis to investigate patterns of the genetic structure of 17 populations (altogether: 538 individuals, 19 loci) of the butterfly Polyommatus coridon, which is a monophagous habitat specialist with a patchy distribution. The butterfly and its larval food plant Hippocrepis comosa reach their northern distribution margin in the study region (southern Lower Saxony, Germany). Butterfly population size increased with habitat area and host plant population size. The genetic differentiation between populations was low but significant $\left(F_{\mathrm{ST}}=0.013\right)$, while no isolation by distance was found. Hierarchical $F_{\mathrm{ST}}$ analysis revealed significant differentiation between a western and an eastern sub-region, which are separated by a river valley. The combination of genetic and ecological data sets revealed that the expected heterozygosity (mean: $18.5 \%$ ) decreased with increasing distance to the nearest $P$. coridon population. The population size of $P$. coridon, habitat area and the amount of available larval food plant had no effect on the genetic diversity. Compared to other regions, genetic diversity of $P$. coridon was reduced, which might be explained by (i) an increasing habitat fragmentation towards the distribution range or (ii) a general reduction of genetic variability towards the northern edge of its distribution.
\end{abstract}

KEYWORDS allozymes, calcareous grasslands, $F$-statistics, genetic diversity, isolation by distance, population size

\section{INTRODUCTION}

Habitat fragmentation is a major threat to biodiversity. Smaller habitats cause smaller populations and increasing isolation leads to reduced colonization rates, therefore enhancing the risk of extinction (Rosenzweig 1995). Species richness and genetic diversity of populations might decrease with increasing habitat fragmentation. Empirical studies show that habitat fragmentation reduces genetic diversity of populations (e.g. Young et al. 1996, Buza et 
al. 2000, Pedersen \& Loeschcke 2001, Keller \& Largiadèr 2003, Williams et al. 2003). Decreasing genetic diversity, an indication of inbreeding, increases the extinction risk of populations due to a decline of fitness (O’Brien \& Evermann 1988, Lacy 1997, Saccheri et al. 1998, Reed \& Frankham 2003). Therefore, conservation biologists pay increasing attention to effects of habitat fragmentation on genetic diversity. Nevertheless, only few published studies on genetic consequences of habitat fragmentation focus on butterflies or moths (Descimon \& Napolitano 1993, Meglécz et al. 1997, Berwaerts et al. 1998, Van Dongen et al. 1998, Schmitt \& Seitz 2002a, Williams et al. 2003).

The intensification of agricultural land-use increased extremely during the last decades in Central Europe, thereby destructing low-impact, semi-natural habitats, such as calcareous grasslands (WallisDeVries et al. 2002). Calcareous grasslands are considered as severely endangered in Germany (Riecken et al. 1994). In southern Lower Saxony, the degree of fragmentation is even enhanced, as chalk bedrocks are naturally rather limited so that the fragmentation in our study region is naturally considerably higher than in southern Germany. Calcareous grasslands rank as the most species-rich habitat for plants and butterflies in Central Europe (van Swaay 2002, WallisDeVries et al. 2002), resulting in high conservation interests. Apart from their ecological importance, these grasslands are a good habitat type to study effects of habitat fragmentation, as they can be clearly distinguished from the surrounding landscape matrix.

To study the effects of fragmentation of calcareous grasslands, the Chalk-hill Blue Polyommatus coridon (Poda) (Lepidoptera: Lycaenidae), a specialized butterfly species of this habitat type (Asher et al. 2001, Van Swaay 2002), was used as a suitable model organism. Its only larval food plant in the study region, the Horseshoe Vetch Hippocrepis comosa L. (Fabaceae), is specialized on calcareous grasslands in Lower Saxony (Garve 1994). Both species, the butterfly and the plant, reach their northern distribution limit in the study region. This is interesting because fragmentation effects are generally supposed to be strongest at the edge of the distribution of a species (Thomas et al. 2001, Bourn \& Thomas 2002). The genetic variability at the distribution range might be reduced, as genetic bottlenecks during range expansion decrease genetic variability with increasing distance from the native range (Stone \& Sunnucks 1993, Lammi et al. 1999, Schmitt et al. 2002).

In this context, the aim of this study was to elaborate the genetic structure and genetic diversity of $P$. coridon at the edge of its distribution. We focus on the following questions:

1. Do P. coridon populations at the northern range margin show reduced genetic heterogeneity? 
2. Has $P$. coridon a significant genetic structure in the studied metapopulation(s)?

3. Is there an isolation by distance between the different subpopulations?

4. Are P. coridon populations of two sub-regions, divided by a river valley, genetically separated?

5. Does population size, habitat area, distance to the nearest $P$. coridon population and the size of the food plant population influence the genetic diversity?

\section{MATERIALS AND METHODS}

\section{Study region and study sites}

The study region is located in the Leine-Weser mountains. We selected the calcareous grasslands in the vicinity of the city of Göttingen in southern Lower Saxony (Germany) as study sites. The landscape is structurally rich with a mosaic of diverse habitat types in this region. Calcareous grasslands can be clearly distinguished from the surrounding landscape and cover $0.26 \%$ of the surface of the study region. Calcareous grasslands are semi-natural and are naturally fragmented. Habitat loss and the degree of fragmentation increased due to agricultural intensification in the last century (WallisDeVries et al. 2002). The valley of the river Leine, with intensive agricultural and urban land use and no naturally occurring calcareous bedrock, separates two regions, a western one with a higher density of calcareous grasslands and an eastern region with more isolated chalk hills (see Figure 1).

\section{Study species}

The Chalk-hill Blue Polyommatus coridon (Poda), (Lycaenidae, Lepidoptera) is a univoltine habitat specialist of calcareous grasslands (Asher et al. 2001, Van Swaay 2002), distributed over major parts of southern and Central Europe (Kudrna 2002). The only larval food plant in the study region is the Horseshoe Vetch Hippocrepis comosa L. (Fabaceae), which is also a calcareous grassland specialist in Lower Saxony (Garve 1994). Both, the plant and the butterfly are close to their northern boundary of distribution in southern Lower Saxony. Only one recent $P$. coridon population is known north of our study area $(50 \mathrm{~km}$ from the most northern population of our study region). This is also the distribution limit of $H$. comosa (Garve 1994). There is a gap of at least $30 \mathrm{~km}$ with no populations of $P$. coridon to the east and west of the study region, while it seems to be well connected to populations further south (unpublished data following the "Niedersächsisches Landesamt für Ökologie" and own observations). 
Population densities of $P$. coridon are generally high (Ebert \& Rennwald 1991, Bink 1992), and the dispersal ability is expected to be moderate, compared to other butterflies (Bink 1992, Asher et al. 2001, Cowley et al. 2001).

\section{Population size, habitat isolation and food plant availability}

We selected 17 populations of $P$. coridon, differing in habitat area, population size, habitat isolation and the amount of available food plant.

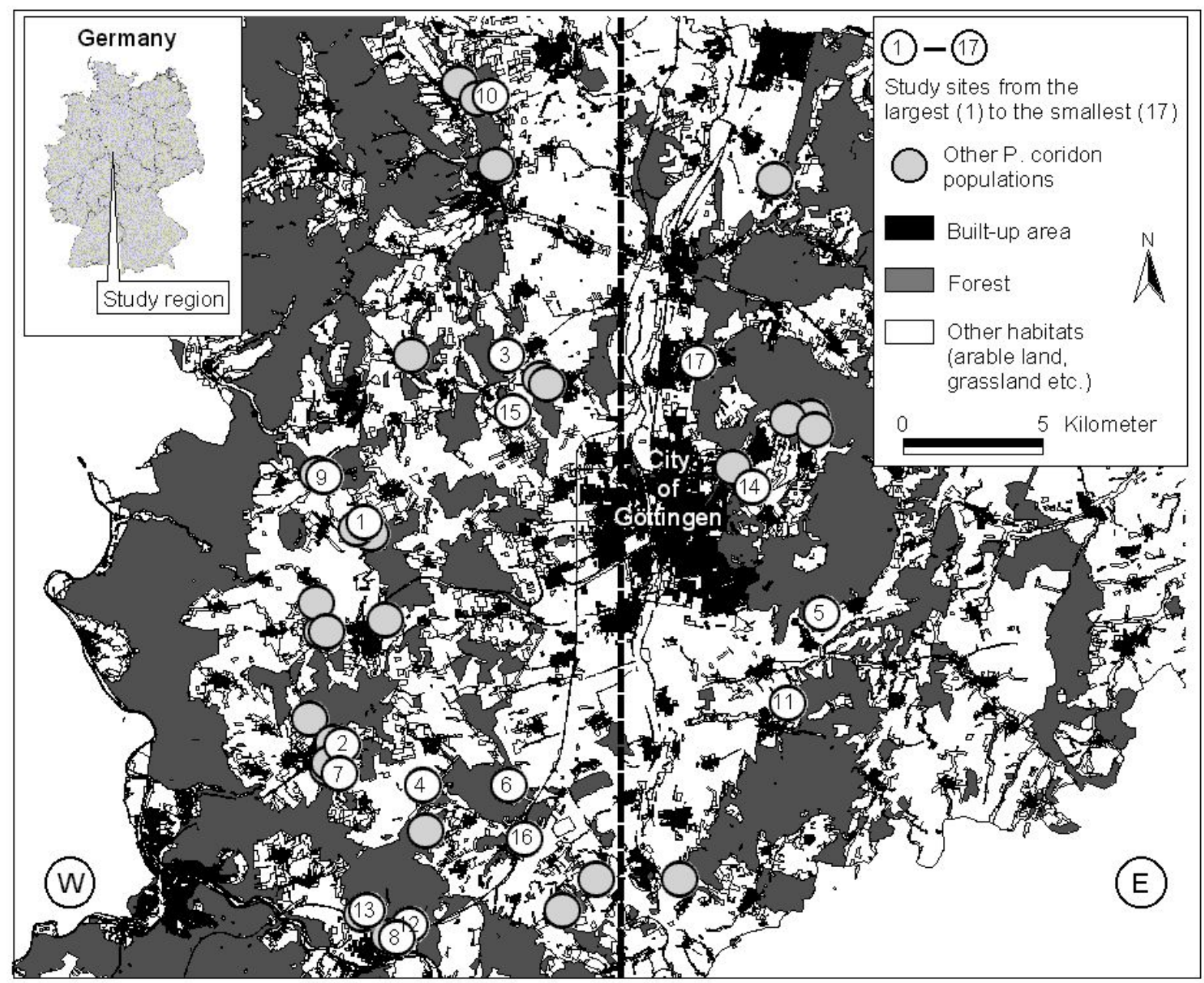

Figure 1 Location of the 17 studied $P$. coridon populations and all further populations in the study region. The region is divided by a river valley (dashed line) in a western (W) and an eastern sub-region (E). The study sites are numbered from the largest (1) to the smallest (17). Details about the study sites are given in Table 1.

The habitat area of each of the 17 study sites was measured with a differential GPS GEOmeter 12L (GEOsat GmbH 1998) in 2000 or 2001. P. coridon individuals were counted during transect walks in 2001 (19 July - 02 August) and in 2002 (23 July - 02 August). Each transect walk was 20 minutes and was done in the time from 10.00 am to $5.00 \mathrm{pm}$ (only two 
times from 5.00 to $6.00 \mathrm{pm}$ ) when weather conditions were suitable for butterfly activity according to Pollard (1977) and Erhardt (1985). To reduce effects of sampling schedule and between-year differences in management, we used the higher individual number of the two years to calculate population sizes. Transect distance was measured with a step counter and individuals were counted within an area of $2.5 \mathrm{~m}$ to each side, thus, allowing a calculation of population density per hectare. By the multiplication with habitat area, we obtained a relative estimation of the population size.

We performed a simple mark-release-recapture experiment (Lincoln-Petersen) for one of the study sites (Kleiner Knüll) in 2002. Hereby, we estimated the highest day populations for males plus the highest day populations for females to be 6.1 times higher than in our calculation based on the transect count (unpublished data J. Krauss). Therefore, we multiplied all population sizes with this factor to obtain more realistic population sizes.

Habitat isolation was defined as the shortest distance to the nearest $P$. coridon population. All sites with the larval food plant H. comosa in the study region were visited in summer 2001 and 2002 to count $P$. coridon during 20 min transect walks. Only patches with at least ten individuals found in one of the two study years were considered as reproductive colonies. This helps to reduce misinterpretations of dispersing individuals. None of these populations was extinct or newly populated between the two study years. All populations of P. coridon are shown in Fig. 1.

Food plant availability and their total population size per habitat were measured in May and June 2001 by transect walks (covering the whole habitat) of all known calcareous grasslands in the study region $(n=298)$.

\section{Sampling, genetic and statistical analyses}

Polyommatus coridon butterflies were caught at the 17 study sites from the 6th to the 9th of August 2001. Only males were collected to avoid damaging of populations. In total, 538 individuals (31 to 33 per study site) were netted. The butterflies were kept in a cold box until the evening. Then they were frozen in liquid nitrogen and stored in a freezer $\left(-80{ }^{\circ} \mathrm{C}\right)$ until allozyme analysis.

Nineteen allozyme loci were studied by means of cellulose acetate electrophoresis using the protocol of Schmitt and Seitz (2001 a). In contrast to earlier publications Acon was buffered in Tris-citrate and not in Tris-maleic acid. Statistical analyses were performed using the software "G-STAT" (Siegismund 1993) for the calculation of allele frequencies $H_{\mathrm{e}}, H_{\mathrm{o}}$, $P_{95}, P_{\text {tot }}, F$ statistics for single loci and genetic distances (Nei 1978), "Genepop" (Raymond \& 
Rousset 1995) for tests on linkage disequilibrium as well as "Arlequin 2.000" (Schneider et al. 2000) for Hardy Weinberg disequilibrium, hierarchical variance analyses and hierarchical F statistics. Trees were calculated from Nei's (1978) genetic distances, using the package PHYLIP (Felsenstein 1993). We used the neighbor-joining (Saitou \& Nei, 1987) and UPGMA methods.

"Statgraphics Plus for Windows 3.0" (Statgraphics 1995) was used for standard statistical procedures as t-test, simple and multiple regressions, and Pearson correlations. We chose stepwise backward elimination for multiple regressions (Sokal \& Rohlf 1995). The genetic variables satisfy the assumption of normal distributed data, while all habitat factors were $\log 10$ transformed to achieve normal distribution. Arithmetic means \pm one standard deviation are given in the text.

\section{RESULTS}

Eighteen of the 19 loci analyzed were polymorphic in the study region. G-3-Pdh was the only monomorphic locus. Based on the allele frequencies of all 17 analyzed populations, representing 538 individuals, we calculated the means of several population genetic parameters. These are the mean number of alleles per locus $(A)$ with $2.42 \pm 0.15$, the expected

Table 1 Habitat factors of the 17 study sites and the genetic variability measures for $P$. coridon.

\begin{tabular}{|c|c|c|c|c|c|c|c|c|c|c|c|}
\hline Locality & Number & $\begin{array}{l}\text { Sub- } \\
\text { Region } \\
\text { West } \\
(\mathrm{W}) \text { or } \\
\text { East (E) }\end{array}$ & $\begin{array}{c}\text { Habitat } \\
\text { area } \\
\text { in } \mathrm{m}^{2}\end{array}$ & $\begin{array}{l}\text { Population } \\
\text { size of } \\
P . \text { coridon } \\
\text { in } \\
\text { individuals }\end{array}$ & $\begin{array}{l}\text { Distance } \\
\text { to next } \\
P . \text { coridon } \\
\text { population } \\
\quad \text { in } m\end{array}$ & $\begin{array}{l}\text { Population } \\
\text { size of } \\
\text { H. comosa } \\
\text { in } \mathrm{m}^{2}\end{array}$ & $\begin{array}{c}\text { Mean } \\
\text { number } \\
\text { of alleles } \\
\text { per locus } \\
A\end{array}$ & $\begin{array}{c}\text { Expected } \\
\text { heterozy- } \\
\text { gosity } H_{\mathrm{e}} \\
\text { in } \%\end{array}$ & $\begin{array}{c}\text { Observed } \\
\text { heterozy- } \\
\text { gosity } H_{0} \\
\text { in } \%\end{array}$ & $\begin{array}{c}\text { Poly- } \\
\text { morphic } \\
\text { loci (total) } \\
P_{\text {tot }} \text { in } \%\end{array}$ & $\begin{array}{c}\text { Poly- } \\
\text { morphic } \\
\text { loci (95\% } \\
\text { level) } P_{95} \\
\text { in } \%\end{array}$ \\
\hline Mühlenberg & 1 & W & 51,395 & 6,570 & 70 & 276 & 2.58 & 18.4 & 18.2 & 78.9 & 42.1 \\
\hline Huhnsberg & 2 & W & 38,776 & 6,812 & 125 & 4,600 & 2.16 & 17.3 & 14.9 & 68.4 & 47.4 \\
\hline Aschenburg & 3 & w & 30,798 & 12,472 & 1,178 & 5,000 & 2.63 & 20.1 & 18.9 & 78.9 & 52.6 \\
\hline Mackenrodt & 4 & W & 20,898 & 3,945 & 1,503 & 700 & 2.42 & 18.5 & 18.3 & 68.4 & 52.6 \\
\hline Lengder Burg & 5 & $E$ & 16,000 & 7,781 & 1,750 & 2,000 & 2.53 & 17.5 & 15.8 & 73.7 & 42.1 \\
\hline Tiefetal & 6 & W & 12,600 & 2,066 & 1,896 & 200 & 2.32 & 16.3 & 16.9 & 63.2 & 52.6 \\
\hline Meenser Heide & 7 & W & 7,443 & 801 & 364 & 65 & 2.58 & 19.5 & 17.6 & 78.9 & 47.4 \\
\hline Hackelberg & 8 & W & 6,338 & 1,581 & 193 & 1,500 & 2.42 & 20.6 & 19.3 & 63.2 & 52.6 \\
\hline Östlicher Riesenberg & 9 & W & 6,251 & 652 & 125 & 100 & 2.58 & 22.6 & 21.5 & 63.2 & 52.6 \\
\hline Fläche 9 & 10 & W & 5,048 & 511 & 150 & 150 & 2.37 & 18.9 & 19.5 & 68.4 & 42.1 \\
\hline Kleiner Knüll & 11 & $E$ & 3,843 & 771 & 3,430 & 700 & 2.37 & 17.9 & 15.6 & 73.7 & 52.6 \\
\hline Vor dem roten Berge & 12 & W & 3,760 & 623 & 582 & 20 & 2.47 & 16.9 & 17.6 & 73.7 & 47.4 \\
\hline Weinberg & 13 & W & 3,578 & 1,757 & 181 & 1,000 & 2.47 & 19.9 & 17.8 & 78.9 & 57.9 \\
\hline Luttertal & 14 & $E$ & 3,244 & 547 & 856 & 600 & 2.32 & 16.7 & 14.6 & 78.9 & 63.2 \\
\hline Kuhberg & 15 & W & 3,207 & 634 & 1,473 & 806 & 2.47 & 18.1 & 17.0 & 68.4 & 42.1 \\
\hline Wetenborn & 16 & W & 3,126 & 350 & 1,896 & 250 & 2.37 & 19.3 & 19.3 & 68.4 & 52.6 \\
\hline Schweineberg & 17 & $E$ & 2,287 & 691 & 3,850 & 650 & 2.11 & 16.8 & 18.1 & 68.4 & 42.1 \\
\hline
\end{tabular}


heterozygosity $\left(H_{\mathrm{e}}\right)$ with $18.5 \pm 1.7 \%$, the observed heterozygosity $\left(H_{\mathrm{o}}\right)$ with $17.7 \pm 1.8 \%$, the percentage of polymorphic loci $\left(P_{\text {tot }}\right)$ with $71.5 \pm 5.9 \%$, and the percentage of polymorphic loci with the most common allele not exceeding $95 \%\left(P_{95}\right)$ with $49.5 \pm 6.2 \%$. See Table 1 for the values of all samples. $H_{\mathrm{e}}$ and $H_{\mathrm{o}}$ were highly correlated $(r=0.765, P=$ 0.0003 ), so that we excluded $H_{\mathrm{o}}$ from all further analyses. $H_{\mathrm{e}}$ was also moderately correlated with the number of alleles $(r=0.578, P=0.015)$, but no further significant correlation between the genetic variables was found (all $P>0.1$ ).

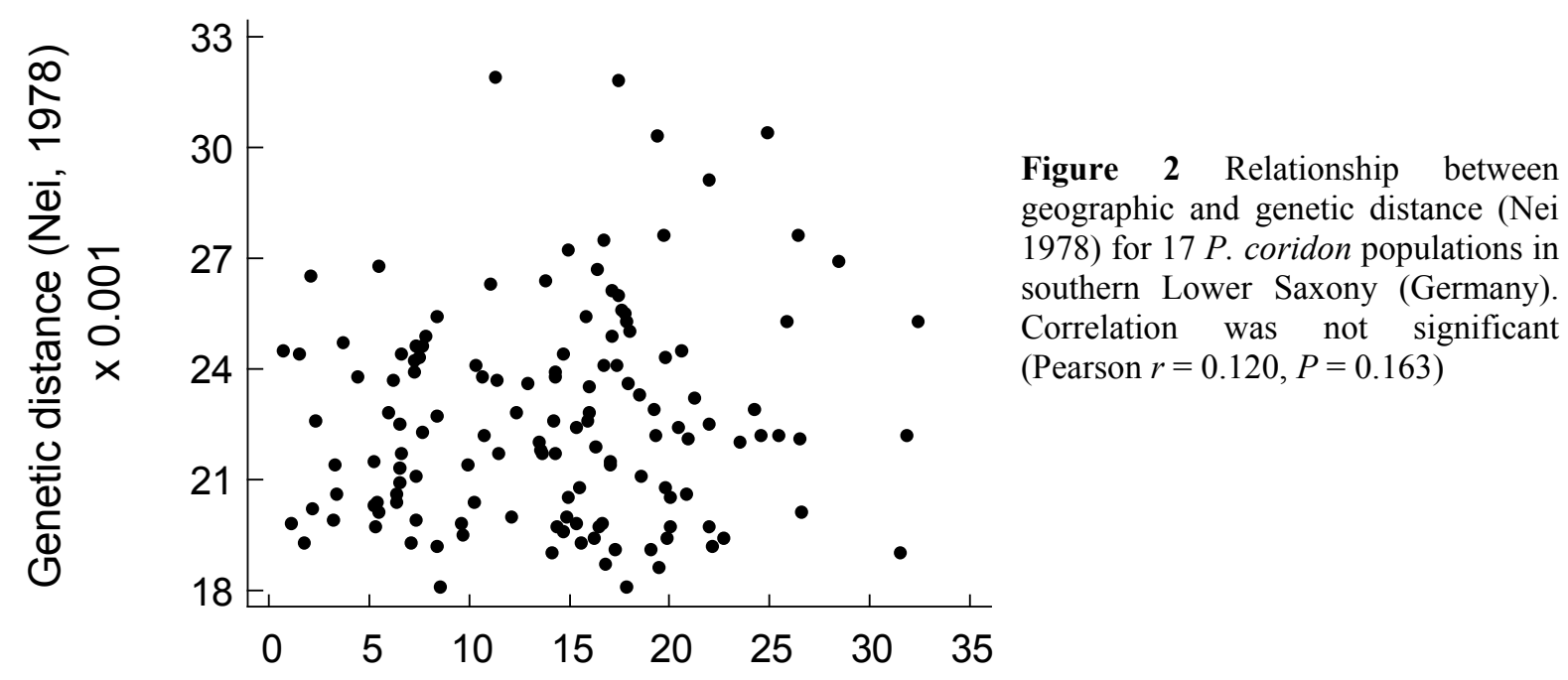

Geographical distance $(\mathrm{km})$

For six of the 17 populations significant deviation from Hardy-Weinberg equilibrium was observed for one to three loci. However, none of the populations showed a significant deviation from Hardy-Weinberg equilibrium after Bonferroni correction. No significant linkage disequilibrium was found after applying the Bonferroni correction. Therefore, further analyses were performed applying standard methods of population genetics.

The overall genetic variance was $1.780(P<0.0001)$ with 0.023 between populations. The resulting $F_{\mathrm{ST}}$ value for the whole study region was $0.013 \pm 0.004(P=0.003)$. Hierarchical $F_{\mathrm{ST}}$ analysis, comparing the study sites of the eastern ridge $(n=4)$ with the ones of the western ridge $(n=13)$ revealed $35.2 \%$ of the difference between habitats between these two sub-regions $\left(F_{\mathrm{RT}}=0.006 ; P=0.003\right)$ while $64.8 \%$ of the differentiation between sites was within the sub-regions $\left(F_{\mathrm{SR}}=0.011, P<0.0001\right)$. In a separate analysis of the two 
sub-regions, the eastern region showed a marginally significant $F_{\mathrm{ST}}(0.015, \mathrm{P}=0.074)$, while there was no significant differentiation between the samples in the western region $\left(F_{\mathrm{ST}}=\right.$ $0.010, P=0.245)$. The populations in the eastern region were significantly more isolated than the populations of the western region (east: $2472 \pm 1408 \mathrm{~m}$, west: $749 \pm 725 \mathrm{~m}$ to the nearest $P$. coridon population, t-test: $t=3.33, P=0.005$ ), while the other habitat factors, area, population size of $P$. coridon and population size of $H$. comosa were not significantly different (all $P>0.1$ ).

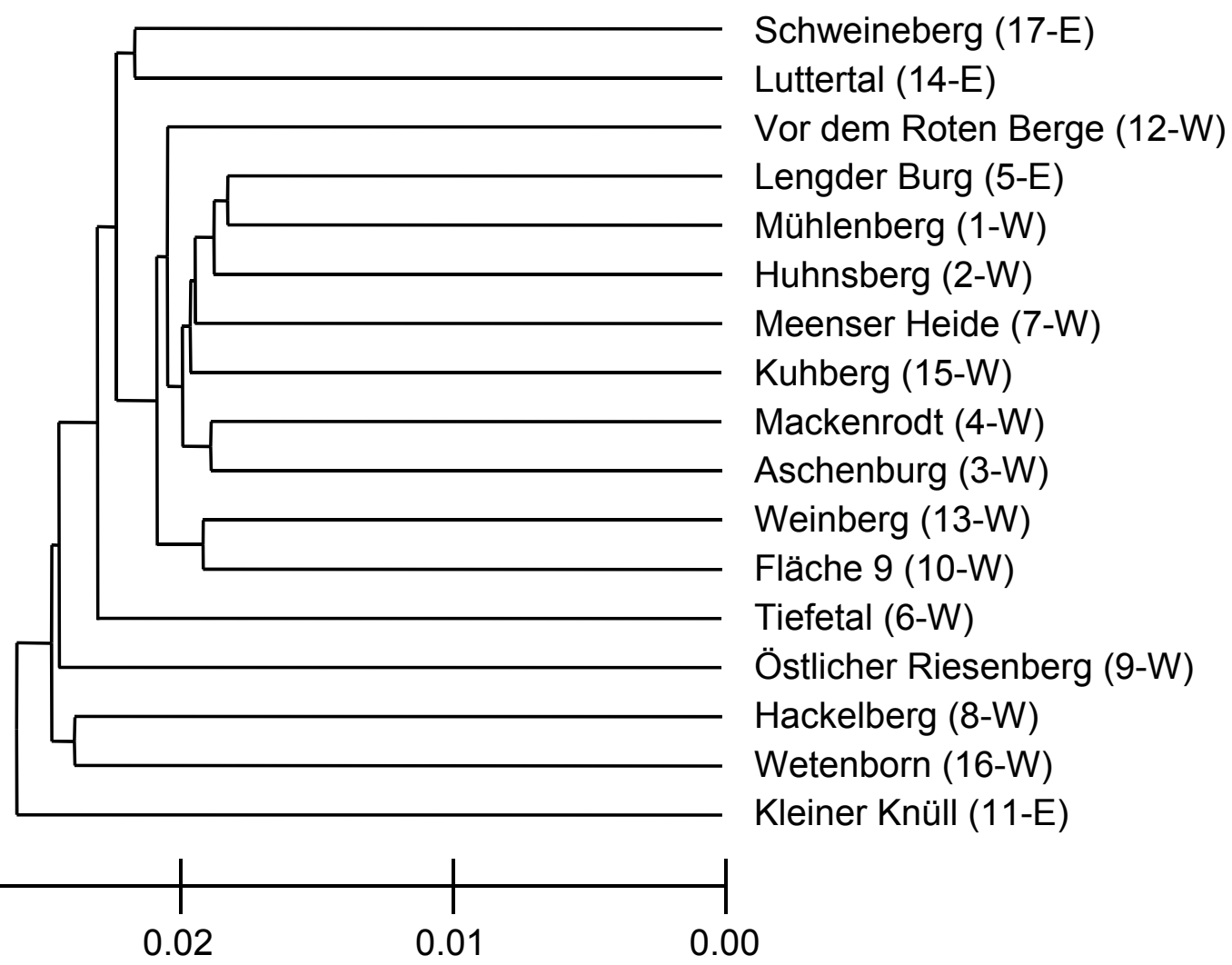

Genetic distance (Nei 1978)

Figure 3 UPGMA phenogram of 17 P. coridon populations in southern Lower Saxony (Germany), based on Nei's genetic distances (Nei 1978). The study sites are numbered from the largest (1) to the smallest (17). The region in divided by a river valley in a western (W) and an eastern sub-region (E). Details about the study sites are given in Table 1.

The inbreeding coefficient $F_{\text {IS }}$ was significant $0.046 \pm 0.016(P<0.0001)$ in the study region. This is mostly due to the high values of two loci (Pep: $0.113 \pm 0.036$; Hbdh: $0.111 \pm 0.030$ ). Nonetheless, these loci had also low $F_{\text {ST }}$ values (Pep: $0.014 \pm 0.008$; Hbdh: $0.009 \pm 0.009$ ). 
The genetic distances (Nei 1978) between the studied populations were on average $0.023 \pm$ 0.003 , ranging from 0.018 to 0.032 . No significant isolation by distance could be found between the populations in the study region (Fig. 2). This is also supported by cluster analyses based on genetic distances (Nei 1978). While no considerable difference was obtained between the neighbor joining and the UPGMA tree, only the latter is shown (Fig. 3).

Table 2 Pearson correlation coefficients $(r)$ are shown for the relations between the independent variables (habitat area, population size of $P$. coridon, distance to the nearest $P$. coridon population and population size of H. comosa) of the 17 calcareous grasslands. All independent factors are $\log _{10}$ transformed. Significance levels are: $\left.* * * P<0.001,{ }^{* *} P<0.01,{ }^{*} P<0.05,{ }^{*}\right) P<0.1$, n.s. $=$ not significant.

\begin{tabular}{l|lll} 
& $\begin{array}{l}\text { Population size of P. } \\
\text { coridon }\end{array}$ & $\begin{array}{l}\text { Distance to the nearest } \\
P . \text { coridon population }\end{array}$ & $\begin{array}{l}\text { Population size of } H . \\
\text { comosa }\end{array}$ \\
\hline Habitat area & $0.892^{* * *}$ & -0.338 n.s. & 0.368 n.s. \\
$\begin{array}{l}\text { Population size of } P . \text { coridon } \\
\begin{array}{l}\text { Distance to the nearest } P . \\
\text { coridon population }\end{array}\end{array}$ & - & -0.153 n.s. & $0.620^{* *}$ \\
\hline
\end{tabular}

In a Pearson correlation matrix of the independent habitat factors, the population size of $P$. coridon significantly depends on habitat area and population size of its larval food plant population (Table 2). For multiple regressions with the habitat factors, we used either the population size of $P$. coridon or the habitat area, because both were highly correlated. The distance to the nearest $P$. coridon population was the only explaining factor $(22.2 \%$ of variance) for the expected heterozygosity in multiple regression models (Fig. 4), whereas the population size of $P$. coridon and of the food plant $H$. comosa did not significantly contribute to the model.

Neither the average number of alleles per locus nor the proportion of polymorphic loci (at the $95 \%$-level or in total) showed any significant correlation in multiple regression models with the three factors (i) distance to the nearest $P$. coridon population, (ii) P. coridon population size and (iii) $H$. comosa population size. The multiple regression models with habitat area instead of the population size of $P$. coridon showed rather similar and none further significant results. 


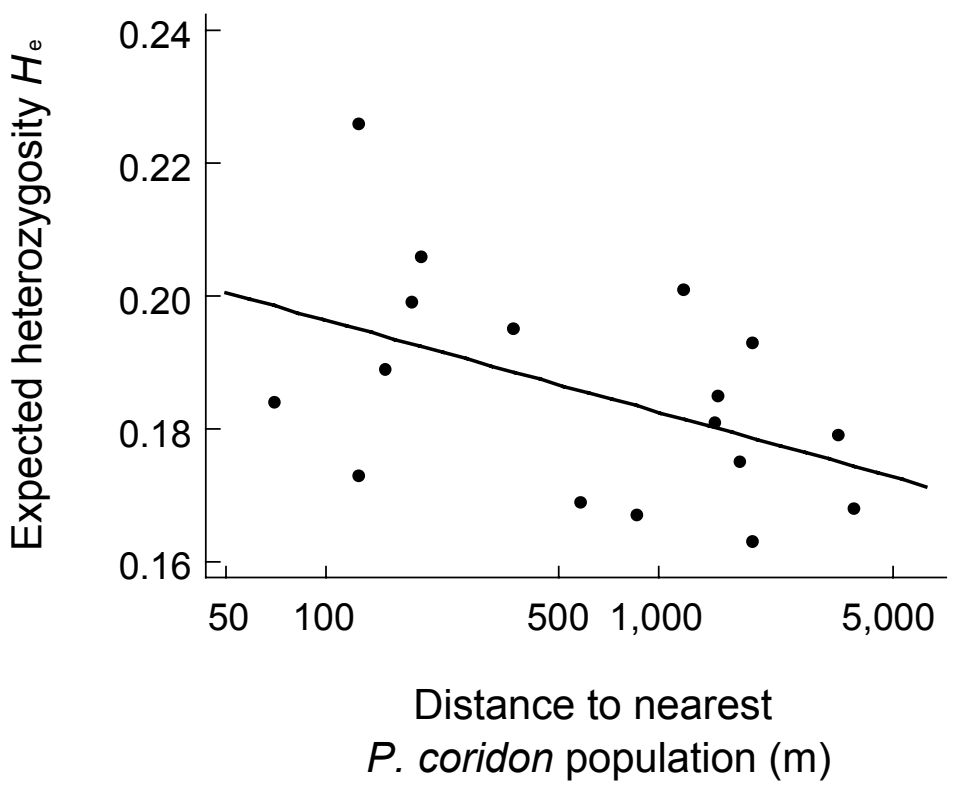

Figure 2 Relationship between expected heterozygosity of $17 P$. coridon populations and the distance to the nearest $P$. coridon population (isolation). $\mathrm{y}=0.224-0.014 \log _{10} \mathrm{x}$ $(F=4.28, r=-0.471, P=0.056)$.

\section{DISCUSSION}

The main objective of this study was to analyse the genetic structure and diversity of $P$. coridon populations at its range margin in relation to habitat area and isolation. We found significant regional genetic differentiation and reduced heterozygosity of the most isolated populations.

\section{Regional differences of the genetic structure}

The observed genetic diversity of the studied P. coridon populations is high in comparison to other allozyme analyses of butterflies (e. g. Debinski 1994, Britten et al. 1995, Kronforst \& Fleming 2001, Nice \& Shapiro 2001, but see the higher genetic diversity for Aglais urticae L. in Vandewoestijne et al. 1999). Previous investigations on a European scale show that $P$. coridon populations in other study regions have an even higher genetic diversity (Schmitt \& Seitz 2001a, b, 2002a, b, Schmitt et al. 2002). The lower genetic diversity of our populations might be due to their marginal position at the northern distribution range. Possible explanations for a loss of genetic variability are bottlenecks during range expansion (Stone \& Sunnucks 1993, Schmitt et al. 2002) or higher fragmentation of habitats and therefore smaller populations at the distribution border. As populations at the range margin are often the smallest, a distinction between both effects is not possible in most cases (Lammi et al. 1999). 


\section{Genetic differentiation between populations}

In contrast to the high genetic diversity within populations, the differentiation between populations is comparatively low $\left(F_{\mathrm{ST}}=1.3 \%\right)$. However the differentiation is significant within our small spatial scale $(0.7-32.4 \mathrm{~km})$ and supports earlier observations for $P$. coridon on a somewhat larger scale $\left(F_{\mathrm{ST}}=1.4 \%, 2.3-147.2 \mathrm{~km}\right)$ in southwestern Germany (Schmitt \& Seitz 2002a). Similar low $F_{\mathrm{ST}}$ values are typically observed for mobile butterflies in open populations (Goulson 1993, Vandewoestijne et al. 1999, Wood \& Pullin 2002).

\section{Isolation by distance}

We could not detect an isolation by distance system between the analysed populations of $P$. coridon. Other butterflies with a patchy distribution developed isolation by distance systems of their genetic structures at regional and local spatial scales (Britten et al. 1995, Johannesen et al 1997, Kegyobadi et al. 1999). However, dispersal ability of species and the extension of the spatial scale within a study are more important for developing an isolation by distance system (Peterson \& Denno 1998). The spatial scale of our study region is quite small, so that dispersal and gene flow might be not sufficiently limited. Nevertheless, even a broader scale in southwestern Germany did not reveal an isolation by distance system for $P$. coridon (Schmitt \& Seitz 2002a). In conclusion, the dispersal ability of $P$. coridon might be underestimated, or the species specific high population sizes of $P$. coridon populations limit genetic drift and therefore prevent the development of an isolation by distance system. In addition the structural diversity within the study region might counteract an isolation by distance system (see below).

\section{Differences between sub-regions}

Hostile areas often impede gene flow. In this context it was shown in previous studies that the genetic structures of butterfly and moth species of open habitats are often influenced by the distribution of forests (Johannesen et al. 1996, Meglécs et al. 1997, Kegyobadi et al. 1999, Schmitt et al. 2000), whereas forest species are influenced by the distribution of open land structures (Berwaerts et al. 1998, van Dongen et al. 1998). Our study area consists of two chalk ridges, which are separated by a five to ten $\mathrm{km}$ wide floodplain with no suitable habitats for P. coridon. We found more than one third (35.2\%) of the genetic variance between populations between these two ridges. The western ridge with a higher density of suitable habitats showed no significant genetic differentiation between the 13 analysed populations, whereas a marginally significant differentiation was detected between the four samples from 
the eastern ridge, with more isolated habitats. Similarly, $P$. coridon populations in southwestern Germany had lower genetic differentiation in regions with high densities of suitable habitats than in comparison to regions with more scattered habitats (Schmitt \& Seitz 2002a). This phenomenon can be also observed on the interspecific level, where species with very scattered and isolated populations mostly show higher differentiation between populations (Debinski 1994, Britten et al. 1994, 1995), while widespread and mobile species often lack major differentiation over greater areas (Goulson 1993, Porter \& Geiger 1995, Vandewoestijne et al. 1999).

\section{Effects of habitat fragmentation on genetic diversity}

Our results indicate a reduced expected heterozygosity in isolated $P$. coridon populations explaining $22 \%$ of the variance. These isolated populations mainly occur in the eastern subregion of our study area with naturally isolated chalk hills. We found no impact of population size, habitat area or food plant availability on the genetic diversity of the populations. Genetic diversity is thereby an indicator for population fitness (Reed \& Frankham 2003).

While most studies of habitat fragmentation only focus on population size or habitat area, the effects of habitat isolation on the genetic diversity are often neglected. Other studies did not separate habitat isolation and population size (Berwaerts et al. 1998, Williams et al. 2003) or found non-significant relations (Buza et al. 2000, Jäggi et al. 2000, Schmitt \& Seitz 2002a). Our results support the finding that expected heterozygosity of the moth Operophtera brumata was negatively related to woodland isolation, but not to area (Van Dongen et al. 1998). Reduced gene flow and possible bottleneck situations in the past might have contributed to the reduction of genetic diversity in isolated habitats in our study region, but explanations remain speculative. Therefore, further studies of butterflies, with different ecological traits, are needed for a better understanding of the genetic consequences of habitat fragmentation for this mobile species group.

Contrary to expectations, we could not confirm the prediction that fragmentation effects are more significant at the range margin (Thomas et al. 2001, Bourn \& Thomas 2002). Thus, genetic variability was not stronger affected by habitat area or population size (although it was for isolation) in comparison to data from southwestern Germany (Schmitt \& Seitz 2002a). The missing correlation between population size and genetic diversity in our study might be explained by relatively small differences in size between the studied populations. Other studies show for several taxonomic groups that decreasing population size (or habitat 
area) result often in reduced genetic diversity (Ellstrand \& Elam 1993, Frankham 1996, Young et al. 1996, Amos \& Harwood 1998).

\section{Conclusions}

We could show that fragmentation, even in a well connected metapopulation system, acts on the genetic diversity of the single sub-populations as we found decreasing expected heterozygosity with increasing distance towards the nearest $P$. coridon population. While the connection of grasslands in the western sub-region seems to be still sufficient for dispersal and gene flow, the populations of the eastern region might start to suffer from reduced heterozygosity. Therefore, we suggest for species conservation, to stop further habitat fragmentation of the remaining calcareous grasslands in southern Lower Saxony.

ACKNOWLEDGEMENTS We thank Frauke Güntzler, Catharina Meinen, Stefanie Spiller, Marina Tsaliki and Viola Vorwald for field assistance and Dagmar Klebsch and Christiane Stürzbecher for help in the laboratory. This work was financially supported by the German Science Foundation (Deutsche Forschungsgemeinschaft, grant number TS 45/13-1/2).

\section{REFERENCES}

Amos W., Harwood J. (1998) Factors affecting levels of genetic diversity in natural populations. Philosophical Transactions of the Royal Society of London Biological Sciences 353, 177-186.

Asher J., Warren M., Fox R., Harding P., Jeffcoate G., Jeffcoate S. (2001) The millennium atlas of butterflies in Britain and Ireland. Oxford University Press, Oxford, United Kingdom.

Berwaerts K., Van Dyck H., Van Dongen S., Matthysen E. (1998) Morphological and genetic variation in the speckled wood butterfly (Pararge aegeria L.) among differently fragmented landscapes. Netherlands Journal of Zoology 48, 241-253.

Bink F.A. (1992) Ecologische Atlas van de Dagvlinders van Noordwest-Europa. Schuyt, Haarem, The Netherlands.

Bourn N.A.D., Thomas J.A. (2002) The challenge of conserving grassland insects at the margins of their range in Europe. Biological Conservation 104, 285-292.

Britten H.B., Brussard P.F., Murphy D.D., Austin G.T. (1994) Colony isolation and isozyme variability of the western seep fritillary, Speyeria-nokomis-apacheana (Nymphalidae), in the western Great-Basin. Great Basin Naturalist 54, 97-105.

Britten H.B., Brussard P.F., Murphy D.D., Ehrlich P.R. (1995) A test for isolation-by distance in Central Rocky Mountain and Great Basin populations of Edith's Checkerspot butterfly (Euphydryas editha). Journal of Heredity 86, 204-210. 
Buza L., Young A., Thrall P. (2000) Genetic erosion, inbreeding and reduced fitness in fragmented populations of the endangered tetraploid pea Swainsona recta. Biological Conservation 93, 177-186.

Cowley M.J.R., Thomas C.D., Roy D.B., Wilson R.J., Leon-Cortes J.L., Gutierrez D., Bulmann C.R., Quinn R.M., Moss D., Gaston K.J. (2001) Density-distribution relationships in British butterflies. I. The effect of mobility and spatial scale. Journal of Animal Ecology 70, 410-425.

Debinski D.M. (1994) Genetic diversity assessment in a metapopulation of the butterfly Euphydryas gilletti. Biological Conservation 70, 25-31.

Descimon H., Napolitano M. (1993) Enzyme polymorphism, wing pattern variability, and geographical isolation in an endangered butterfly species. Biological Conservation 66, 117123.

Ebert G., Rennwald E. (1991) Die Schmetterlinge Baden-Württembergs. Band 1, Tagfalter I., Band 2, Tagfalter II. Eugen Ulmer Verlag, Stuttgart, Germany.

Ellstrand N.C., Elam D.R. (1993) Population genetic consequences of small population size: Implications for plant conservation. Annual Review of Ecology and Systematics 24, 217-242

Erhardt A. (1985) Wiesen und Brachland als Lebensraum für Schmetterlinge. Eine Fallstudie im Tavetsch (GR). Birkhäuser Verlag, Basel, Switzerland.

Felsenstein J. (1993) PHYLIP (Phylogeny Inference Package) Version 3.5.c. Department of Genetics, University of Washington: Seattle, Washington, USA.

Frankham R. (1996) Relationship of genetic variation to population size in wildlife. Conservation Biology 10, 1500-1508.

Garve E. (1994) Atlas der gefährdeten Farn- und Blütenpflanzen in Niedersachsen und Bremen. Kartierung 1982 - 1992. Naturschutz und Landschaftspflege in Niedersachsen 30, 1-895.

Goulson D. (1993) Allozyme variation in the butterfly, Maniola jurtina (Lepidoptera: Satyrinae) (L.): evidence for selection. Heredity 71, 386-393.

Jäggi C., Wirth T., Baur B. (2000) Genetic variability in subpopulations of the asp viper (Vipera aspis) in the Swiss Jura mountains: implications for a conservation strategy. Biological Conservation 94, 69-77.

Johannesen J., Veith M., Seitz A. (1996) Population genetic structure of the butterfly Melitaea didyma (Nymphalidae) along a northern distribution range border. Molecular Ecology 5, 259-267.

Johannesen J., Schwing U., Seufert W., Seitz A., Veith M. (1997) Analysis of gene flow and habitat patch network for Chazara briseis (Lepidoptera: Satyridae) in an agricultural landscape. Biochemical Systematics and Ecology 25, 419-427.

Keller I., Largiadèr C.R. (2003) Recent habitat fragmentation caused by major roads leads to reduction of gene flow and loss of genetic variability in ground beetles. Proceedings of the Royal Society of London Biological Sciences 270, 417-423. 
Keyghobadi N., Roland J., Strobeck C. (1999) Influence of landscape on the population genetic structure of the alpine butterfly Parnassius smintheus (Papilionidae). Molecular Ecology 8, 1481-1495.

Kronforst M.R., Fleming T.H. (2001) Lack of genetic differentiation among widely spaced subpopulations of a butterfly with home range behaviour. Heredity 86, 243-250.

Kudrna O. (2002) The distribution atlas of European butterflies. Distribution maps of all species. Oedippus 20, 1-343.

Lacy R.C. (1997) Importance of genetic variation to the viability of mammalian populations. Journal of Mammalogy 78, 320-335.

Lammi A., Siikamäki P., Mustajärvi K. (1999) Genetic diversity, population size, and fitness in central and peripheral populations of a rare plant Lychnis viscaria. Conservation Biology 13, 10691078.

Meglécz E., Pecsenye K., Peregovits L., Varga Z. (1997) Effects of population size and habitat fragmentation on the genetic variability of Parnassius mnemosyne populations in NE Hungary. Acta Zoologica Academiae Scientiarum Hungaricae 43, 183-190.

Nei M. (1978) Estimation of average heterozygosity and genetic distance from a small number of individuals. Genetics 89, 583-590.

Nice C.C., Shapiro A.M. (2001) Population genetic evidence of restricted gene flow between host races in the butterfly genus Mitoura (Lepidoptera: Lycaenidae). Annals of the Entomological Society of America 94, 257-267.

O'Brien S.J., Evermann J.F. (1988) Interactive influence of infectious disease and genetic diversity in natural populations. Trends in Ecology and Evolution 3, 254-259.

Pedersen A.A., Loeschcke V. (2001) Conservation genetics of peripheral populations of the mygalomorph spider Atypus affinis (Atypidae) in northern Europe. Molecular Ecology 10, 1133-1142.

Peterson M.A., Denno R.F. (1998) The influence of dispersal and diet breadth on patterns of genetic isolation by distance in phytophagous insects. The American Naturalist 152, 428-446.

Pollard E. (1977) A method for assessing changes in the abundance of butterflies. Biological Conservation 12, 115-134.

Porter A.H., Geiger H. (1995) Limitations to the inference of gene flow at regional geographic scales an example from the Pieris napi group (Lepidoptera, Pieridae) in Europe. Biological Journal of the Linnaean Society 54, 329-348.

Raymond M., Rousset F. (1995) Genepop (V. 1.2.): a population genetics software for exact tests and ecumenicism. Journal of Heredity 86, 248-249.

Reed D.H., Frankham R. (2003) Correlation between fitness and genetic diversity. Conservation Biology 17, 230-237. 
Riecken U., Ries U., Ssymank A. (1994) Rote Liste der gefährdeten Biotoptypen der Bundesrepublik Deutschland. Kilda-Verlag, Greven, Germany.

Rosenzweig M.L. (1995) Species diversity in space and time. Cambridge University Press, Cambridge, UK.

Saccheri I., Kuussaari M., Kankare M., Vikman P., Fortelius W., Hanski I. (1998) Inbreeding and extinction in a butterfly metapopulation. Nature 392, 491-494.

Saitou N., Nei M. (1987) The neighbor-joining method: a new method for reconstructing phylogenetic trees. Molecular Biology and Evolution 4, 406-425.

Schmitt T., Varga Z., Seitz A. (2000) Forest as dispersal barriers for Erebia medusa (Nymphalidae, Lepidoptera). Basic and Applied Ecology 1, 53-59.

Schmitt T., Seitz A. (2001a) Intraspecific structuring of Polyommatus coridon (Lycaenidae). Nota lepidopterologica 24, 53-63.

Schmitt T., Seitz A. (2001b) Allozyme variation in Polyommatus coridon (Lepidoptera: Lycaenidae): identification of ice-age refugia and reconstruction of post-glacial expansion. Journal of Biogeography 28, 1129-1136.

Schmitt T., Seitz A. (2002a) Influence of habitat fragmentation on the genetic structure of Polyommatus coridon (Lepidoptera: Lycaenidae): implications for conservation. Biological Conservation 107, 291-297.

Schmitt T., Seitz A. (2002b) Postglacial distribution area expansion of Polyommatus coridon (Lepidoptera: Lycaenidae) from its Ponto-Mediterranean glacial refugium. Heredity 89, 20-26.

Schmitt T., Geiß1 A., Seitz A. (2002) Postglacial colonisation of western Central Europe by Polyommatus coridon (Poda 1761) (Lepidoptera: Lycaenidae): evidence from population genetics. Heredity 88, 26-34.

Schneider S., Roessli D., Excoffier L. (2000) Arlequin, version 2.000 - a software for population genetics data analysis. Antropology, University of Genève, Genève, Switzerland.

Siegismund H.R. (1993) G-Stat, Version 3 genetical statistical programs for the analysis of population data. The Arboretum, Royal Veterinary and Agricultural University, Horsholm, Denmark.

Sokal R.R., Rohlf F. (1995) Biometry. Freeman, NY, USA.

Statgraphics (1995) Statgraphics plus for Windows, Version 3.0. Manugistics, Inc, Rockville, MD, USA.

Stone G.N., Sunnucks P. (1993) Genetic consequences of an invasion through a patchy environment the cynipid gallwasp, Andricus quercuscalicis (Hymenoptera: Cynipidae). Molecular Ecology 2, 251-268.

Thomas J.A., Bourn N.A.D., Clarke R.T., Stewart K.E., Simcox D.J., Pearman G.S., Curtis R., Goodger B. (2001) The quality and isolation of habitat patches both determine where butterflies persist in fragmented landscapes. Proceedings of the Royal Society of London Biological Sciences 268, 1791-1796. 
Vandewoestijne S., Neve G., Baguette M. (1999) Spatial and temporal population genetic structure of the butterfly Aglais urticae L. (Lepidoperta, Nymphalidae). Molecular Ecology 8, 1539-1543.

Van Dongen S., Backeljau T., Matthysen E., Dhondt A.A. (1998) Genetic population structure of the winter moth (Operophtera brumata L.) (Lepidoptera, Geometridae) in a fragmented landscape. Heredity 80, 92-100.

Van Swaay C.A.M. (2002) The importance of calcareous grasslands for butterflies in Europe. Biological Conservation 104, 315-318.

WallisDeVries M.F., Poschlod P., Willems J.H. (2002) Challenges for the conservation of calcareous grasslands in northwestern Europe: integrating the requirements of flora and fauna. Biological Conservation 104, 265-273.

Williams B.L., Brawn J.D., Paige K.N. (2003) Landscape scale genetic effects of habitat fragmentation on a high gene flow species: Speyeria idalia (Nymphalidae). Molecular Ecology 12: 11-20.

Wood B.C., Pullin A.S. (2002) Persistance of species in a fragmented urban landscape: the importance of dispersal ability and habitat availability for grassland butterflies. Biodiversity and Conservation 11, 1451-1468.

Young A., Boyle T., Brown T. (1996) The population genetic consequences of habitat fragmentation for plants. Trends in Ecology and Evolution 11, 413-418. 


\section{SUMMARY}

Occurrence and population density of species in a local site are mainly explained by the four factors: habitat size, habitat isolation, habitat quality, and landscape context. But not all species are affected equally, and species with different life-history traits, like habitat specialists and generalists, might react differently on changes of the cultural landscape.

The aim of this study was to evaluate the effects of habitat fragmentation on temporal dynamics (immigration, extinction, turnover) of butterfly communities (habitat specialists and generalists) (chapter 2). Further, it was tested, how habitat fragmentation and landscape context affect the species richness and population density of butterflies (chapter 3 ), and the species richness and species density of plants (chapter 4). Finally, the effect of habitat fragmentation on the population genetic structure of the butterfly Polyommatus coridon was studied (chapter 5).

In a first approach it was tested, if immigration, extinction, and turnover of butterfly species changed with area and isolation of 31 calcareous grasslands. Therefore, two surveys from 1996 and 2000 were compared. The area of the study sites ranged from 0.03 to 5.14 ha, the isolation index from 2,100 to 86,000 (edge-to-edge distance 55 - 1,894 m). In both study years, the total number of individuals as well as species sampled across all sites were rather similar. Rates of extinction and turnover were higher for habitat specialists than for generalists, whereas generalists had higher immigration rates. Extinction and turnover rates decreased with increasing fragment size for both, specialist and generalist butterflies, but specialists showed a significantly stronger decrease (steeper slope) with increasing fragment size than generalists. Immigration rates increased with area. As a result, species number of habitat specialists declined on small habitats but not on large habitats between 1996 and 2000 . No significant impact of habitat isolation on the butterfly community was found. The data suggest that large habitat fragments are of special importance for the conservation of the specialized, most endangered butterfly species, whereas habitat isolation appears to be less important, as butterflies can cope with the habitat mosaic in the study region.

In a second approach the effects of habitat area, isolation, quality, and landscape context on species richness and population densities of butterflies was tested. Thirty-two calcareous grasslands, differing in size and isolation (see above), were surveyed in randomised transect walks. Number and cover of blooming plant species were recorded as measure of habitat quality, but both factors were correlated with habitat area. Species numbers of habitat specialist and habitat generalist butterflies decreased with decreasing habitat area whereas specialists again had the steeper slope. Generalists, but not specialists, were positively 
affected by landscape diversity (with marginal significance). Effects of landscape diversity were scale-dependent and significant only at the smallest scale (landscape context within a $250 \mathrm{~m}$ radius around the habitat). Habitat isolation was not related to the number of specialist and generalist species. Population density of butterflies increased with habitat area, whereas habitat isolation and landscape diversity did not show any effects. In conclusion, habitat area again was the most important predictor of butterfly community structure. Habitat isolation had no effect and landscape diversity appeared to be important for generalist butterflies only.

In a third approach it was tested, if patterns found for butterflies also occur for plants. Four surveys between 1996 and 2001 were pooled to reach complete species richness of plants on the 31 studied calcareous grasslands. Again, habitat area was the most important factor affecting species richness, but for plants, habitat specialists were not more affected than generalists. This may have been caused by high habitat heterogeneity in large grasslands offering a microhabitat mosaic for non-specialists and by delayed extinction of long-living plant specialists in small grasslands. Habitat isolation as well as landscape diversity did not affect plant species richness significantly. Analyses with equal sample size (= species density) on all 31 calcareous grasslands did not result in significant relations between species number and habitat area, habitat isolation or landscape diversity, therefore supporting the habitatheterogeneity, but not the area-per se hypothesis.

In a fourth approach, a habitat specialist butterfly for calcareous grasslands was studied with population genetic methods. The study species Polyommatus coridon is a monophagous butterfly and its larval food plant Hippocrepis comosa is also specialised on calcareous grasslands. Both species reach their northern distribution margin in the study region (southern Lower Saxony, Germany). Seventeen populations were sampled with 31 - 33 individuals for allozyme electrophoresis. Nineteen loci of each of the 538 individuals were tested. The genetic differentiation between populations was low but nevertheless significant, while no isolation by distance structure was found. Analyses revealed significant genetic differentiation between a western sub-region (not genetically differentiated), with well connected populations and an eastern sub-region (genetically differentiated) with more isolated populations. A river valley separates both sub-regions. Expected heterozygosity decreased with increasing distance to the next $P$. coridon population, whereas the population size of $P$. coridon and the highly correlated habitat area and the amount of available larval food plant had no effect on genetic diversity. A comparison with other regions using literature data showed that genetic diversity of $P$. coridon was reduced. This might be explained (i) by an 
increasing habitat fragmentation towards the distribution range or (ii) by a general reduction of genetic variability towards the northern edge of its distribution.

Summarizing the four studies, habitat area of calcareous grasslands in the study region is of major importance for communities of vascular plants and butterflies, whereas habitat isolation had no effect, and landscape context revealed effects on generalist butterflies only. Nevertheless, single species might be affected by habitat isolation. Thus, expected heterozygosity of $P$. coridon was reduced in isolated habitats. Landscape management should protect large calcareous grasslands, as only these ensure the survival of the endangered habitat specialists. Maintenance of small calcareous grasslands might keep them attractive for generalist species and dispersing specialists. The creation of new calcareous grasslands as stepping stone habitats seems less advisable, as the studied species are able to cope with the current degree of habitat isolation. Connecting habitats, e.g. with Field margin strip programmes, could enhance habitat generalists and dispersing habitat specialists. 


\section{ZUSAMMENFASSUNG}

Die Größe und Isolation von Lebensräumen, die Habitatqualität und die Landschaftsstruktur der Umgebung gelten als die wichtigsten Ursachen für die Verteilung von Arten und ihre lokalen Populationsdichten. Dies trifft jedoch nicht alle Organismen gleichermaßen. Arten mit unterschiedlichen life-history traits, wie z. B. Habitatspezialisten und Generalisten, können auf die Veränderung der Kulturlandschaft unterschiedlich reagieren.

Ziel dieser Arbeit war es, die Auswirkungen der Habitatfragmentierung auf die zeitliche Dynamik (Immigration, Extinktion, Turnover) von Tagfalterlebensgemeinschaften (Habitatspezialisten und Generalisten) zu untersuchen (Kapitel 2). Die Folgen der Habitatfragmentierung und der Landschaftsstruktur wurden für Tagfalterarten und Populationsdichten (Kapitel 3), sowie für Artenzahl und Artendichte von Blütenpflanzen untersucht (Kapitel 4). Schließlich wurden die Auswirkungen der Fragmentierung auf die Populationsgenetik des Tagfalter Polyommatus coridon analysiert (Kapitel 5).

Zunächst wurde untersucht, wie sich Immigrations-, Extinktions- und Turnoverraten von Tagfaltern auf fragmentierten Kalkmagerrasen hinsichtlich der Habitatgröße und der Habitatisolation verhalten. Hierzu wurden Aufnahmen von 31 Kalkmagerrasen aus dem Jahr 1996 mit Aufnahmen von 2000 verglichen. Die Habitatgröße variierte dabei von 0,03 bis 5,14 ha, der Isolationsindex von 2100 bis 86000 (Luftliniendistanz 55 - 1894 m). In beiden Jahren waren die Arten- und Individuenzahlen über alle Flächen ähnlich. Habitatspezialisten zeigten im Mittel eine signifikant höhere Extinktions- und Turnoverrate als die Habitatgeneralisten, während letztere eine höhere Immigrationsrate zeigten. Extinktions- und Turnoverraten nahmen mit zunehmender Habitatgröße ab, wobei Habitatspezialisten stärker beeinflusst waren als Generalisten. Beiden Artengruppen hatten auf großen Flächen höhere Immigrationsraten als auf kleinen Flächen. Dies resultierte in einer Abnahme von Artenzahlen der Habitatspezialisten zwischen 1996 und 2000 auf den kleinen Habitatflächen. Die Habitatisolation hatte keinen signifikanten Einfluss auf die Tagfalterlebensgemeinschaft. Für den Schutz der gefährdeten Habitatspezialisten ist daher die Habitatgröße besonders wichtig. Dagegen scheinen die Tagfalterarten mit der Isolation der Habitate größtenteils zurecht zu kommen.

In einem zweiten Ansatz wurde untersucht, wie sich sowohl Habitatgröße und Isolation, als auch Habitatqualität und die Landschaftsstruktur der Umgebung auf die Artenvielfalt und die Populationsdichte von Tagfaltern auswirken. Mit Transektbegehungen wurden 32 Kalkmagerrasen unterschiedlicher Habitatgröße und Isolation untersucht (siehe oben). Zusätzlich wurden die Blütenpflanzenartenzahl und die Blütenpflanzendeckung als Maß für 
die Habitatqualität aufgenommen. Beide Faktoren korrelierten jedoch mit der Habitatgröße, so dass sie nicht unabhängig geprüft werden konnten. Die Artenzahl von Habitatspezialisten und Generalisten sank mit abnehmender Habitatgröße, wobei die Spezialisten stärker beeinflusst wurden als die Generalisten. Die Artenzahl der Generalisten stieg andererseits auch mit zunehmender Landschaftsdiversität der Umgebung an, allerdings nur auf der kleinsten räumlichen Skala von $250 \mathrm{~m}$ um das Habitat. Die Isolation hatte keinen Einfluss auf die Artenzahlen. Die Populationsdichten der Tagfalter waren wie die Artenzahlen positiv mit der Habitatgröße korreliert, wohingegen Landschaftsstruktur und Isolation keinen Effekt hatten. Als Konsequenz ist erneut die Habitatgröße der wichtigste Faktor für die Tagfalterlebensgemeinschaft, während die Isolation keine Rolle spielt und eine heterogene Landschaftsstruktur der Umgebung nur die Generalisten fördert.

Im dritten Ansatz wurden die Muster, die für Tagfalter gefunden wurden, auch für die Blütenpflanzen untersucht. Hierbei wurden vier botanische Aufnahmen zwischen 1996 und 2001 zusammengefasst, um eine komplette Erfassung der Arten von 31 Kalkmagerrasen zu erreichen. Erneut war die Habitatgröße der wichtigste Faktor für die Anzahl der Arten. Es konnte jedoch kein stärkerer Einfluss für Habitatspezialisten gegenüber Generalisten nachgewiesen werden. Dies lag möglicherweise an der hohen Habitatheterogenität der großen Kalkmagerrasen, die auch den nicht spezialisierten Pflanzenarten Wuchsmöglichkeiten bieten. Darüber hinaus könnten auf kleinen Kalkmagerrasen noch Habitatspezialisten vorkommen, die erst im Laufe der nächsten Jahrzehnte auf Grund einer sogenannten Extinktionschuld aussterben. Habitatisolation und Landschaftsstruktur der Umgebung spielten keine modifizierende Rolle für die Blütenpflanzenartenzahl. Die Artendichte (mit gleichem Aufwand erfasste Artenzahlen) auf allen 31 Flächen war weder von der Habitatgröße noch von der Isolation oder Landschaftsstruktur beeinflusst. Dies ist ein Hinweis auf die Habitatheterogenitäts-Hypothese und spricht gegen die Areal per se- Hypothese als Ursachen für Arten-Areal-Beziehungen.

Im vierten Ansatz wurde eine auf Kalkmagerrasen spezialisierte Tagfalterart populationsgenetisch näher untersucht. Die Art Polyommatus coridon frisst als Raupe monophag am Hufeisenklee Hippocrepis comosa, welcher ebenfalls auf Kalkmagerrasen spezialisiert ist. Beide Arten sind in Süd-Niedersachsen an ihrer nördlichen Verbreitungsgrenze. Von 17 P. coridon Populationen wurden je 31-33 Tiere pro Population für Allozym Elektrophoresen entnommen. Neunzehn Loci wurden bei den insgesamt 538 Individuen untersucht. Die Populationen waren genetisch signifikant unterschiedlich, bildeten jedoch keine isolation by distance Struktur. Das Flusstal der Leine mit seiner intensiven 
Agrarlandschaft unterteilte die Populationen genetisch in eine westliche Region mit genetisch homogenen und gut vernetzten Populationen und eine genetisch inhomogene östliche Region mit isolierten Populationen. Insgesamt war die erwartete genetische Heterozygotie auf isolierten Flächen reduzierter als auf nicht isolierten Flächen. Die Populationsgröße des Tagfalters, die damit eng korrelierte Habitatgröße und die Größe der Futterpflanzenpopulation hatten keinen Einfluss auf die genetische Diversität. Eine niedrigere genetische Diversität in der Untersuchungsregion am Rand der nördlichen Verbreitungsgrenze wurde im Vergleich zur Kernregion an Hand von Literaturdaten festgestellt. Dies kann sowohl mit einer höheren Habitatfragmentierung in den Randregionen erklärt werden, als auch mit genetischen Flaschenhälsen während der Ausbreitung.

Als Schlussfolgerung aus den vier Arbeiten wird klar, dass die Habitatgröße der Kalkmagerrasen in der Untersuchungsregion um Göttingen entscheidend für die Artenlebensgemeinschaft der Blütenpflanzen und Tagfalter ist, wohingegen die Isolation der Habitate kaum eine Rolle spielt und die Landschaftsstruktur der Umgebung nur für die Generalisten unter den Tagfaltern von Bedeutung ist. Für einzelne Arten kann auch die Isolation einen negativen Einfluss haben. So ist die erwartete genetische Heterozygotie von $P$. coridon auf isolierten Flächen verringert. Als Managementmaßnahme wird empfohlen, die großen Kalkmagerrasen unter besonderen Schutz zu stellen, da nur sie ein dauerhaftes Überleben der gefährdeten Habitatspezialisten gewährleisten. Kleinen Flächen können Generalisten noch als Habitat und dispergierenden Arten als Zwischenstopp dienen. Sie sollten also ebenfalls erhalten werden. Trittsteinbiotope mit Kalkmagerrasencharakter neu anzulegen ist dagegen weniger sinnvoll. Eine Biotopvernetzung, z. B. mit Ackerrandstreifenprogrammen, könnte dagegen Generalisten und dispergierende Habitatspezialisten fördern. 


\section{DANKSAGUNG}

Herrn Prof. Dr. Teja Tscharntke danke ich sehr herzlich für die Bereitstellung des Themas, die gute Betreuung und die stete Diskussionsbereitschaft. Herrn Prof. Dr. Stefan Vidal danke ich für die freundliche Übernahme des Korreferats. Besonders bedanken möchte ich mich bei Herrn PD Dr. Ingolf Steffan-Dewenter für die gute Zusammenarbeit und die große Hilfsbereitschaft bei allen fachlichen Fragen.

Der Deutschen Forschungsgemeinschaft danke ich für die finanzielle Unterstützung des Projektes (TS 45/13-1,2).

Herrn Prof. Dr. Alfred Seitz (Universität Mainz, Zoologisches Institut) und Mitarbeitern (insbesondere Frau Dagmar Klebsch und Frau Christiane Stürzbecher) sowie Herrn Dr. Thomas Schmitt (Universität Trier, Institut für Biogeographie) danke ich für die gute Kooperation bei der Analyse und Auswertung der genetischen Daten.

Besonders bedanken möchte ich mich bei allen MitarbeiterInnen des Fachgebiets Agrarökologie für die gute Arbeitsatmosphäre. Alexandra-Maria Klein, PD Dr. Andreas Kruess, Indra Roschewitz, Martin Schmidt und Dr. Carsten Thies danke ich für zahlreiche fachliche Diskussionen und Unterstützung in verschiedensten Bereichen. Thomas Alfert danke ich für die GPS-Einführung, Christof Bürger für GIS- und Computerhilfen, Doreen Gabriel für die Makroeinführung, Volker Gaebele für Kalkmagerrasenunterstützung, Christian H. Schulze für Tagfalterunterstützung, Joachim Kuhnhenne und Friedrich Sundmacher für Computerhilfen und Hella Grabe, Susanne Jahn und Susanne Schiele für "Technisches".

Bedanken möchte ich mich bei den Eignern und Pflegern der Kalkmagerrasen, die mir immer einen Zugang zu ihren Flächen ermöglicht haben, sowie den Behörden, die mich mit Kartenmaterial und Genehmigungen versorgt haben, hierbei im Besonderen Herrn Dr. Reinhard Altmüller und Frau Dr. Annemarie Schacherer (Niedersächsisches Landesamt für Ökologie), Herrn Bertram Preuschoff und Herrn Roland Dillenburger (Untere Naturschutzbehörden Kreis bzw. Stadt Göttingen), der Oberen Naturschutzbehörde in Braunschweig, den Unteren Naturschutzbehörden der Landkreise Northeim und Heiligenstadt sowie dem Regierungspräsidium Kassel.

Mein Dank gilt auch den Tagfalterspezialisten aus der Region Göttingen, hierbei besonders Herrn Gerd Brunken, Herrn Dr. Kai Füldner, Herrn Dr. Hans Joger und Herrn Dr. Thomas Meineke für die Überprüfung kritischer Arten.

Schließlich möchte ich mich für die tolle Unterstützung ganz besonders bei meinen Eltern, meinem Bruder mit Familie und meinen Freunden und Bekannten aus aller Welt bedanken. 


\section{PUBLIKATIONEN}

Krauss J., Schmitt T., Seitz A., Steffan-Dewenter I., Tscharntke T. (submitted) Effects of habitat fragmentation on the genetic structure of the monophagous butterfly Polyommatus coridon along its northern range margin. Molecular Ecology.

Krauss J., Klein A.-M., Steffan-Dewenter I., Tscharntke T. (accepted) Effects of habitat area, isolation, and landscape diversity on plant species richness of calcareous grasslands. Biodiversity and Conservation.

Krauss J., Steffan-Dewenter I., Tscharntke T. (2003) How does landscape context contribute to effects of habitat fragmentation on diversity and population density of butterflies? Journal of Biogeography 30, 889-900.

Krauss J., Steffan-Dewenter I., Tscharntke T. (submitted) Local species immigration, extinction, and turnover of butterflies in relation to habitat area and habitat isolation. Oecologia.

Krauss J., Steffan-Dewenter I., Tscharntke T. (2002) Welche Faktoren bestimmen das Vorkommen von Tagfaltern - Arealgröße, Isolation, Landschaftsstruktur oder Habitatqualität? Verhandlungen der Gesellschaft für Ökologie 32, 35.

Krauss J., Steffan-Dewenter I., Tscharntke T. (2002) Butterflies on calcareous grasslands. VII $^{\text {th }}$ European Congress of Entomology. Abstract 186, page 191.

Tscharntke T., Bürger C., Eber S., Gabriel D., Grabe H., Grönmeier M., Holzschuh A., Jahn S., Klein A.-M., Klipfel S., Kluth S., Krauss J., Kruess A., Lehmann K., Poveda K., Roschewitz I., Schiele S., Schmidt M., Schulze C., Steffan-Dewenter I., Sundmacher F., Thies C., Veddeler D., Westphal C. (2002) Wenn der Räuber seinen Feind verliert. Wissenschaftsmagazin der Georg-August-Universität Göttingen 1, 40-46.

Krauß J., Steffan-Dewenter I., Tscharntke T. (2001) Tagfalter auf fragmentierten Kalkmagerrasen - Hat sich die Lebensgemeinschaftsstruktur in den letzten Jahren geändert? Mitteilungen der Deutschen Gesellschaft für Allgemeine und Angewandte Entomologie 13, 525-528.

Krauß J., Funke W. (1999) Extraordinary high density of Protura in a windfall area of young spruce plants. Pedobiologia 43, 44-46.

Krauß J., Spelda J., Funke W. (1998) Mesofauna des Bodens. Die Entwicklung von WaldBiozönosen nach Sturmwurf (ed. Fischer H.), pp. 241-248. ecomed, Landsberg, Germany. 
Funke W., Kenter B., Baumann K., Schwarz E., Bellmann H., Krauß J., Werth H. (1995) Tiergesellschaften auf Windwurfflächen in Süddeutschland - Untersuchungen an Arthropoden- und Avizönosen. Veröffentlichungen des Projekts für Angewandte Ökologie 12, 131-142.

Krauß J., Funke W. (1995) Collembolen- und Proturengesellschaften in Fichtenforsten Auswirkungen von Windwurf, Kalk- und Kompostgaben. Mitteilungen der Deutschen Gesellschaft für Allgemeine und Angewandte Entomologie 10, 99-102. 


\section{LEBENSLAUF}

Name: Jochen Krauß (international: Krauss)

Geburtstag und Ort: 10.11.1967 in Stuttgart, Deutschland

1999 - 2003 Promotion im Fachgebiet Agrarökologie der Universität Göttingen bei Prof. Dr.

Teja Tscharntke. Gefördert von der Deutschen Forschungsgemeinschaft (DFG).

1998 - 1999 Wissenschaftlicher Angestellter der Universität Bern (Schweiz) in der

Arbeitsgruppe Ethologie und Naturschutz im Projekt "Tourismus und Wild" mit dem

Schwerpunkt: "Aktivität von Gämsen (Rupicapra rupicapra)" bei Prof. Dr. Paul Ingold.

1996/1997 Durchführung einer 9-monatigen Fernreise durch Asien.

1994/1995 Staatsexamens- und Diplomarbeit an der Universität Ulm zum Thema "Zur

Collembolen- und Proturenfauna in Fichtenforsten - Auswirkungen von Windwurf, Kalk- und Kompostgaben" in der Abteilung Ökologie und Morphologie der Tiere bei Prof. Dr. Werner Funke.

1989 - 1996 Studium Biologie und Chemie Lehramt an der Universität Ulm, seit 1993 zusätzlich Studium Biologie Diplom.

1987 - 1989 Wehrdienst (15 Monate), Jobben, 5-monatige Fernreise durch Asien

1987 Abschluss der Allgemeinen Hochschulreife in Marbach am Neckar. 